\section{Keywords: Waste Removal Salt \\ Solubility \\ Equilibrium}

Retention: Permanent

\title{
Tank 31H Saltcake Dissolution Tests
}

C. J. Martino

M. R. Poirier

Publication date: February 27, 2003

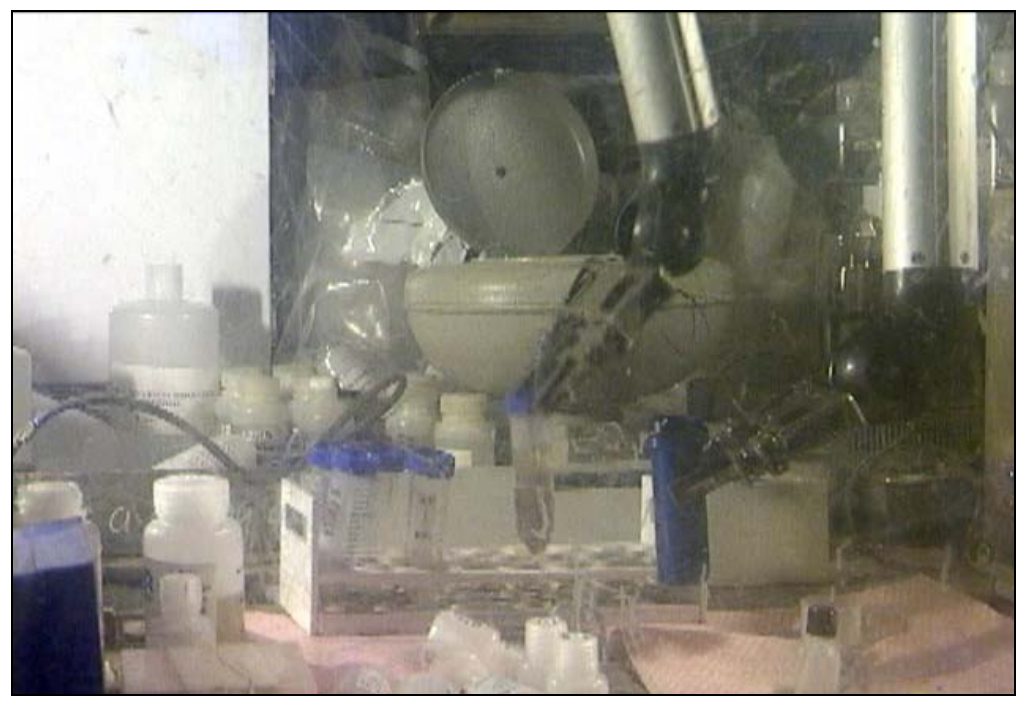

Westinghouse

Savannah River Company

Aiken, SC 29808

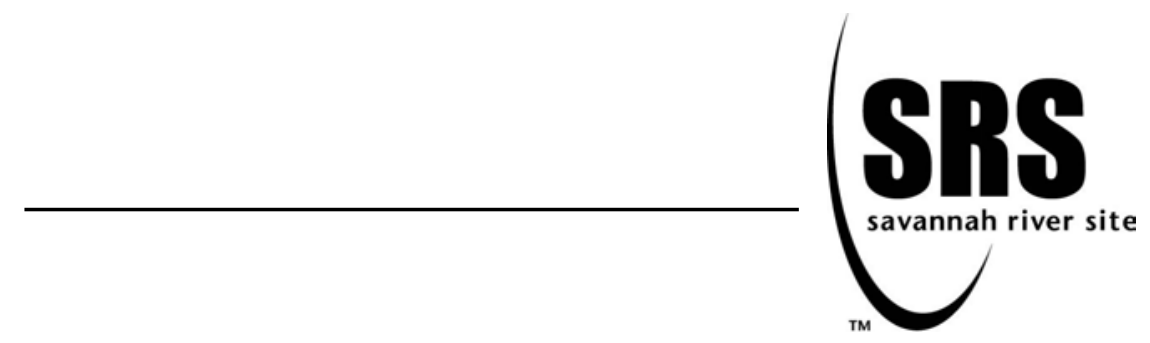


This document was prepared in conjunction with work accomplished under Contract No. DE-AC09-96SR18500 with the U. S. Department of Energy.

\section{DISCLAIMER}

This report was prepared as an account of work sponsored by an agency of the United States Government. Neither the United States Government nor any agency thereof, nor any of their employees, makes any warranty, express or implied, or assumes any legal liability or responsibility for the accuracy, completeness, or usefulness of any information, apparatus, product or process disclosed, or represents that its use would not infringe privately owned rights. Reference herein to any specific commercial product, process or service by trade name, trademark, manufacturer, or otherwise does not necessarily constitute or imply its endorsement, recommendation, or favoring by the United States Government or any agency thereof. The views and opinions of authors expressed herein do not necessarily state or reflect those of the United States Government or any agency thereof.

This report has been reproduced directly from the best available copy.

Available for sale to the public, in paper, from: U.S. Department of Commerce, National Technical Information Service, 5285 Port Royal Road, Springfield, VA 22161, phone: (800) 553-6847, fax: (703) 605-6900

email: orders@ntis.fedworld.gov

online ordering: http://www.ntis.gov/help/index.asp

Available electronically at http://www.osti.gov/bridge

Available for a processing fee to U.S. Department of Energy and its contractors, in paper, from: U.S. Department of Energy, Office of Scientific and Technical Information, P.O. Box 62, Oak Ridge, TN 37831-0062,

phone: (865)576-8401,

fax: (865)576-5728

email: $\underline{\text { reports@ adonis.osti.gov }}$ 


\section{Summary}

Two multiple-wash dissolution tests were performed on Tank $31 \mathrm{H}$ actual-waste saltcake. The tests contacted $60 \mathrm{~g}$ of saltcake with a series of ten small aliquots of dissolution fluid (7 to $45 \mathrm{~g}$ ). The dissolution fluid was different for the two tests, either inhibited water or an actual-waste $5.2 \mathrm{M} \mathrm{Na}^{+}$ solution. Dissolution of Tank $31 \mathrm{H}$ saltcake with inhibited water was accomplished with an approximately $1: 1$ cumulative mass ratio of diluent to salt. Dissolution of Tank $31 \mathrm{H}$ saltcake with $5.2 \mathrm{M} \mathrm{Na}^{+}$solution remained incomplete after a 3.3:1 cumulative mass ratio of diluent to salt.

The dissolved salt supernates were characterized and profiles were created for the removal of individual components during the Tank $31 \mathrm{H}$ salt dissolution tests. Several general categories were used to describe the compounds that dissolve similarly during saltcake dissolution. Hydroxide, cesium, nitrite, and aluminate are eluted during the earliest stages of salt dissolution. Due to its low concentration in the saltcake sample, phosphate is also removed in the early stages of dissolution relative to the sodium and nitrate. Of the major saltcake components, carbonate and sulfate were removed during the latest dissolution stages. Several of the minor components, including strontium, were only partially dissolved during the tests.

The residual insoluble solid material from the dissolution of Tank $31 \mathrm{H}$ saltcake with inhibited water was $87 \mathrm{wt} \%$ gibbsite and bayerite and $7 \mathrm{wt} \%$ hematite, while the material from the less-complete dissolution with the $5.2 \mathrm{M} \mathrm{Na}^{+}$solution was primarily sodium salts of carbonate and sulfate. Information is provided on the actinide content to aid in an initial criticality analysis and in an analysis of required actinide removal. Both the as-received Tank $31 \mathrm{H}$ salt and the residual insoluble solids after salt dissolution with inhibited water had $a^{235} \mathrm{U}$ enrichment of $17 \%$. 
WSRC-TR-2002-00388

Revision 0

\section{Approvals/Review}

\section{Authors:}

C. J. Martino, SRTC Waste Processing Technology

Date

M. R. Poirier, SRTC Waste Processing Technology

Date

\section{Design Check:}

J. L. Siler, SRTC Waste Processing Technology

Date (per Manual E7, Procedure 2.40)

\section{Customer:}

J. A. Pike, HLW Program Development and Integration

Date

R. E. Edwards, Manager, HLW Program Development and Integration

Date

\section{Management:}

W. B. Van Pelt, SRTC Waste Processing Technology

Date

W. L. Tamosaitis, SRTC Waste Processing Technology

Date

Page iv 


\section{Table of Contents}

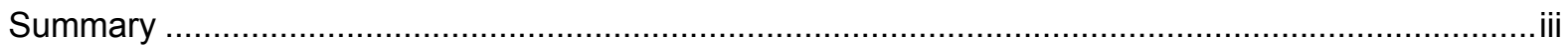

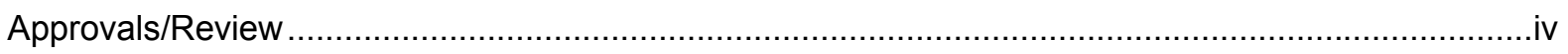

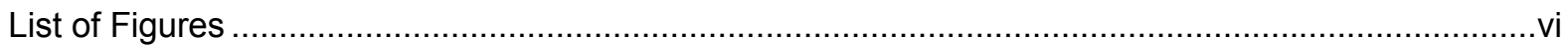



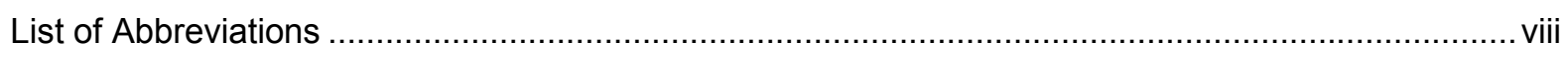

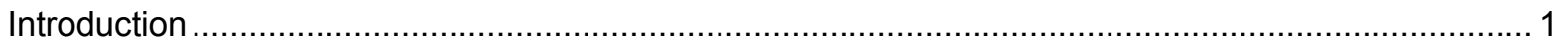

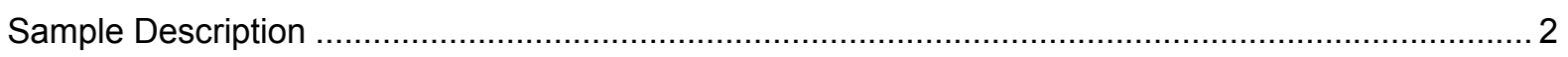



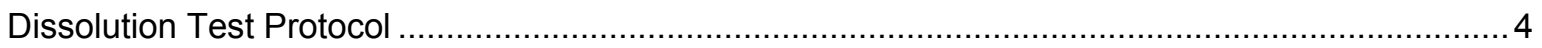

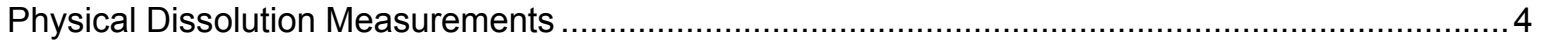

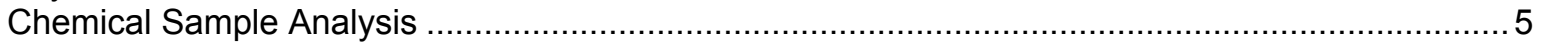

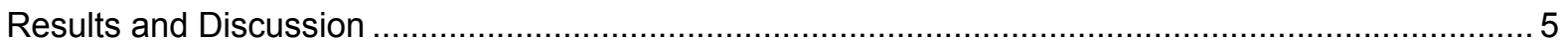

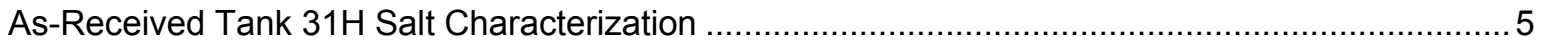

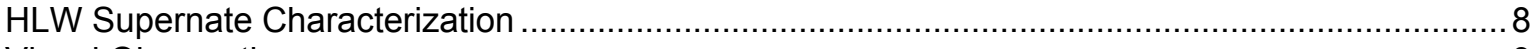

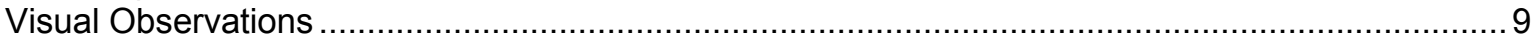

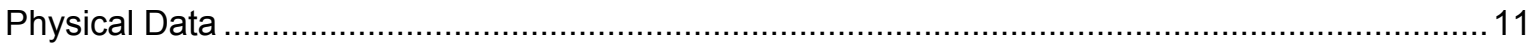

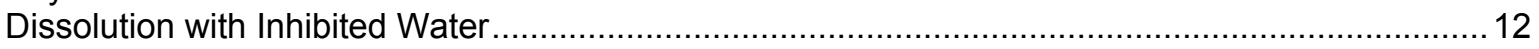

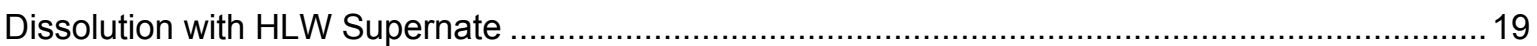

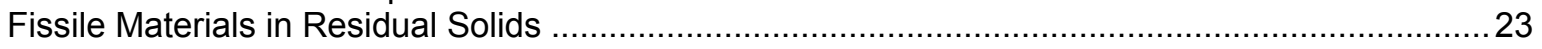

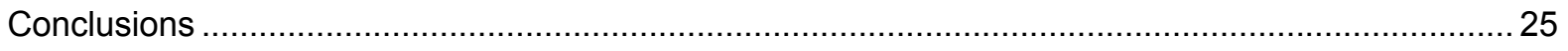



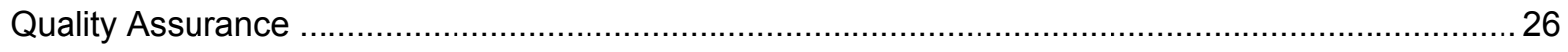

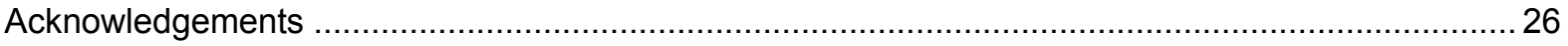

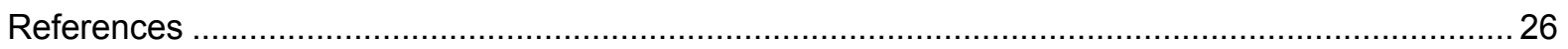

Appendix 
WSRC-TR-2002-00388

Revision 0

\section{List of Figures}

Cover Photo: The Multiple-Wash Dissolution of Tank 31H Saltcake in the Shielded Cells...................

Figure 1: Tank 31H Salt Sample HTK-513. ........................................................................ 2

Figure 2: Interior of Tank 31H Salt Sample HTK-513........................................................... 3

Figure 3: Jars of Tank 31H Saltcake from Sample HTK-513................................................... 3

Figure 4: Multiple-Wash Dissolution Test. .......................................................................... 4

Figure 5: Tank 31H Salt Dissolution With HLW Supernate Material, Mixing Step (Left) and Decanting

Step (Right) of the Second Wash.

Figure 6: Clarified Supernate and Residual Salt after the Second Wash Using Inhibited Water (Left) and HLW Supernate (Right).

Figure 7: Residual Insoluble Solids Resultant from Salt Dissolution using Inhibited Water (Left) and

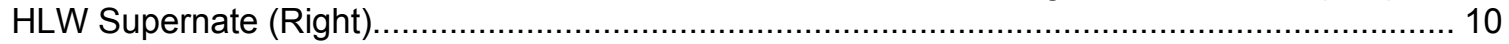

Figure 8: Mass Fraction of Saltcake Remaining Undissolved During Multiple-Wash Dissolution Tests. Includes Actual-Waste Tests of Dissolution of Tank 31H Salt With Inhibited Water and HLW Supernate Compared With Previous Tests with Simulant Saltcake.

Figure 9: Densities of Supernatant Liquids Decanted During Multiple-Wash Dissolution Tests. Includes Actual-Waste Tests of Dissolution of Tank 31H Salt With Inhibited Water and HLW Supernate Compared With Previous Tests with Simulant Saltcake.

Figure 10: Supernate Composition for the Multiple-Wash Dissolution of Tank 31H Saltcake with Inhibited Water

Figure 11: ${ }^{137} \mathrm{Cs}$ and ${ }^{90} \mathrm{Sr}$ Activity from the Multiple-Wash Dissolution of Tank $31 \mathrm{H}$ Saltcake with

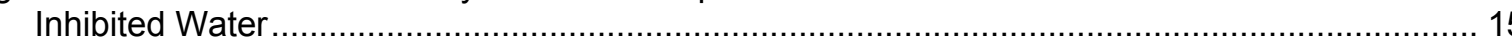

Figure 12: Dissolution Profile for the Major Components from the Dissolution of Tank 31H Saltcake

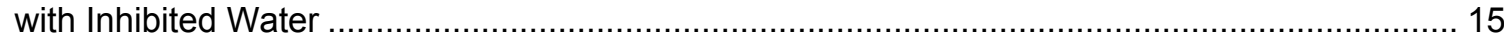

Figure 13: Dissolution Profile for the Minor Components from the Dissolution of Tank 31H Saltcake

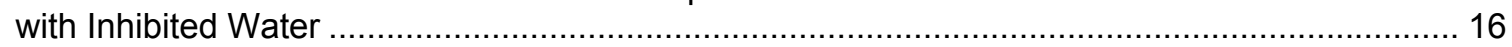

Figure 14: Dissolution Profile for Radionuclides from the Dissolution of Tank 31H Saltcake with Inhibited Water ...................................................................................................... 16

Figure 15: Chromatographic Representation of the Dissolution of Tank 31H Saltcake with Inhibited

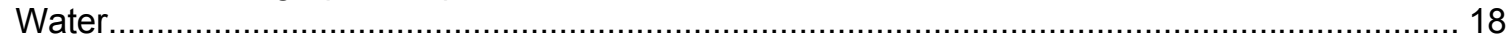

Figure 16: XRD for the Residual Insoluble Solids from the Dissolution of Tank 31H Saltcake with

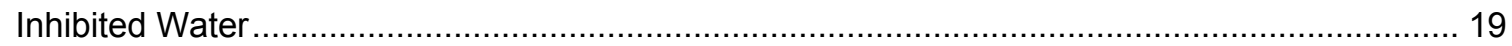

Figure 17: Supernate Composition for the Multiple-Wash Dissolution of Tank 31H Saltcake with HLW



Figure 18: Dissolution Profile for the Major Components from the Dissolution of Tank 31H Saltcake with HLW Supernate

Figure 19: Dissolution Profile for the Minor Components from the Dissolution of Tank 31H Saltcake

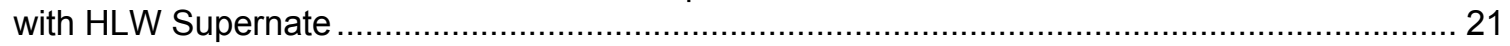

Figure 20: Dissolution Profile for Radionuclides from the Dissolution of Tank 31H Saltcake with HLW

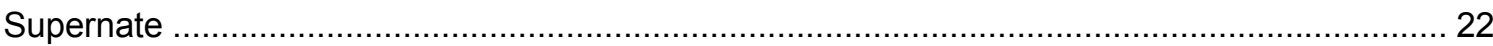

Figure 21: XRD for the Residual Insoluble Solids from the Dissolution of Tank 31H Saltcake with

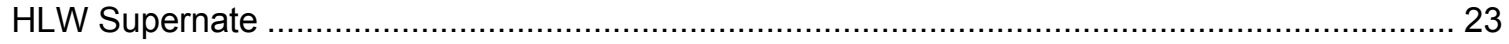




\section{List of Tables}

Table 1: Ionic Composition of Tank 31H Saltcake, Compared With Tank $41 \mathrm{H}$ and $37 \mathrm{H}$ Salt. 6

Table 2: Radionuclides in As-Received Tank 31H Saltcake ...................................................... 7

Table 3: Summary of HLW Supernate Characterization (from Tanks $21 \mathrm{H} / 24 \mathrm{H} / 26 \mathrm{~F}$ ) ....................... 8

Table 4: Summary of Sample Results Useful to Nuclear Criticality Safety Evaluations ....................24

Table 5: Analysis of ${ }^{125} \mathrm{Sb}$ and ${ }^{126} \mathrm{Sn}$ in Samples from the Dissolution of Tank $31 \mathrm{H}$ Saltcake with Inhibited Water

Table 6: Test Data and ICP-ES Results for Tank 31H Salt Dissolution with Inhibited Water ......

Table 7: Results from IC Anions, Wet Chemistry, Rad. Chem., and ICP-MS for Tank 31H Salt Dissolution with Inhibited Water

Table 8: Mass Removed (in Grams) During the Dissolution of $60.764 \mathrm{~g}$ of As-Received Tank 31H Saltcake by Multiple Washes with Inhibited Water.

Table 9: Test Data and ICP-ES Results for Tank 31H Salt Dissolution with HLW Supernate (from Tanks $21 \mathrm{H} / 24 \mathrm{H} / 26 \mathrm{~F})$

Table 10: Results from IC Anions, Wet Chemistry, Rad. Chem., and ICP-MS for Tank 31H Salt Dissolution with HLW Supernate (from Tanks $21 \mathrm{H} / 24 \mathrm{H} / 26 \mathrm{~F}$ )

Table 11: Mass Removed (in Grams) During the Dissolution of $61.052 \mathrm{~g}$ of As-Received Tank 31H Saltcake by Multiple Washes with HLW Supernate (from Tanks 21H/24H/26F) .......................40

Table 12: Residual Insoluble Solids from Tank 31H Saltcake Dissolution......................................42

Table 13: Characterization of As-Received Tank 31H Saltcake (Sample HTK-513) ........................ 44

Table 14: Characterization of HLW Supernate Composite (from Tanks 21H/24H/26F) .................. 46 
WSRC-TR-2002-00388

Revision 0

\section{List of Abbreviations}

\begin{tabular}{|c|c|}
\hline ADS & Analytical Development Section \\
\hline DWPF & Defense Waste Processing Facility \\
\hline HLW & high-level waste \\
\hline ICP-ES & Inductively coupled plasma emission spectroscopy \\
\hline ICP-MS & Inductively coupled plasma mass spectroscopy \\
\hline IW & inhibited water \\
\hline n.d. & not determined \\
\hline SPF & Saltstone Processing Facility \\
\hline SRS & Savannah River Site \\
\hline SRTC & Savannah River Technology Center \\
\hline SWPF & Salt Waste Processing Facility \\
\hline XRD & X-rav diffraction \\
\hline
\end{tabular}




\section{Introduction}

The Savannah River Site (SRS) has 49 carbon steel tanks that currently house 37 million gallons of High Level Waste (HLW) in the form of saltcake, salt supernate, and sludge solids. Before the current inventory of saltcake can be processed at the Saltstone Processing Facility (SPF) or the proposed Salt Waste Processing Facility (SWPF), the saltcake must be dissolved and transferred out of the waste tanks. Additional information is required for the investigation of the influence of chemistry on tank waste properties and behavior during salt retrieval and the impacts of these operations on downstream processes. This study provides data useful to understanding the salt equilibrium thermodynamics and the transient physical and chemical properties of the dissolved salt solutions.

The following are the major objectives of this work:

- Determine the potential variability in dissolved saltcake composition, which is useful in examining impacts on downstream processes.

- Provide equilibrium data useful to the planning and modeling of saltcake dissolution.

- Provide salt characterization information for Tank 31H.

Individual salts in a high ionic-strength matrix have a tendency to exhibit solubilities lower than their solubility in water and in dilute sodium hydroxide. This phenomenon is apparent from the equilibrium composition of the supernatant fluid when saltcake is contacted with dissolution fluid in a quantity far less than that required for complete dissolution. During batch-wise salt dissolution schemes, the highly soluble salts and the components in the interstitial liquid are removed in the early batches, while the less soluble salts dissolve in the later batches. This causes a variation in composition of the dissolved salt stream fed to subsequent salt processing operations. The manifestation of this variation in dissolved salt chemistry is dependent on several factors, including the original saltcake composition, the dissolution fluid composition, and the dissolution temperature. The analysis of actual-waste salt dissolution is important because the dissolution profiles of the less-soluble components are highly dependent on the initial saltcake composition.

The focus of most of the previous actual-waste salt dissolution tests at SRS has been in support of criticality analysis, where the goal was the characterization of the residual insoluble material after the sodium salts had been removed completely. The dissolution of Tank $41 \mathrm{H}$ salt criticality samples illustrate the variety in these tests, where insoluble material was prepared by washing salt with an excess of $0.015 \mathrm{M} \mathrm{NaOH}^{1,2,3}$ The only studies that investigated chemistry at intermediate degrees of salt dissolution were the tests performed in support of Tank $41 \mathrm{H}$ corrosion inhibition planning. ${ }^{4,5}$

Working with the Tanks Focus Area, SRTC performed saltcake dissolution tests on actual-waste saltcake from Tank $31 \mathrm{H}$. This testing is based on the methodology devised for a recent salt dissolution program involving Hanford actual-waste saltcake. ${ }^{6,7,8}$ A portion of saltcake is dissolved under well-mixed conditions with small aliquots of dissolution fluid. The supernatant liquid is decanted and characterized, providing a profile of components removed during the dissolution process. These multiple-wash tests are very small-scale versions of a full in-tank dissolution process, and thus are of interest to engineers and planners. In preparation for this work, a series of smallscale dissolution studies were performed to determine solid-liquid equilibrium in SRS and Hanford saltcake surrogates. ${ }^{9}$ 
WSRC-TR-2002-00388

Revision 0

\section{Sample Description}

Sample HTK-513, a vertical core sample of saltcake from the surface of Tank $31 \mathrm{H}$, was pulled in early August 2002 and delivered to the SRTC Shielded Cells. The sample was opened on August $6^{\text {th }}$, 2002 in Cell 14. The portion of the sampler that contained the sample, as seen in Figure 1 and Figure 2, was an approximately eight-inch-long section of pipe. This inner portion was split along its length to allow for the retrieval of the sample. This apparatus was similar to the grab sampler used previously for sampling the residual mounds of solids in Tank 19F. While initial planning indicated the need for the use of several smaller samplers, this apparatus was successfully used to retrieve a single saltcake sample that exceeded the program need of $200 \mathrm{~g}$.

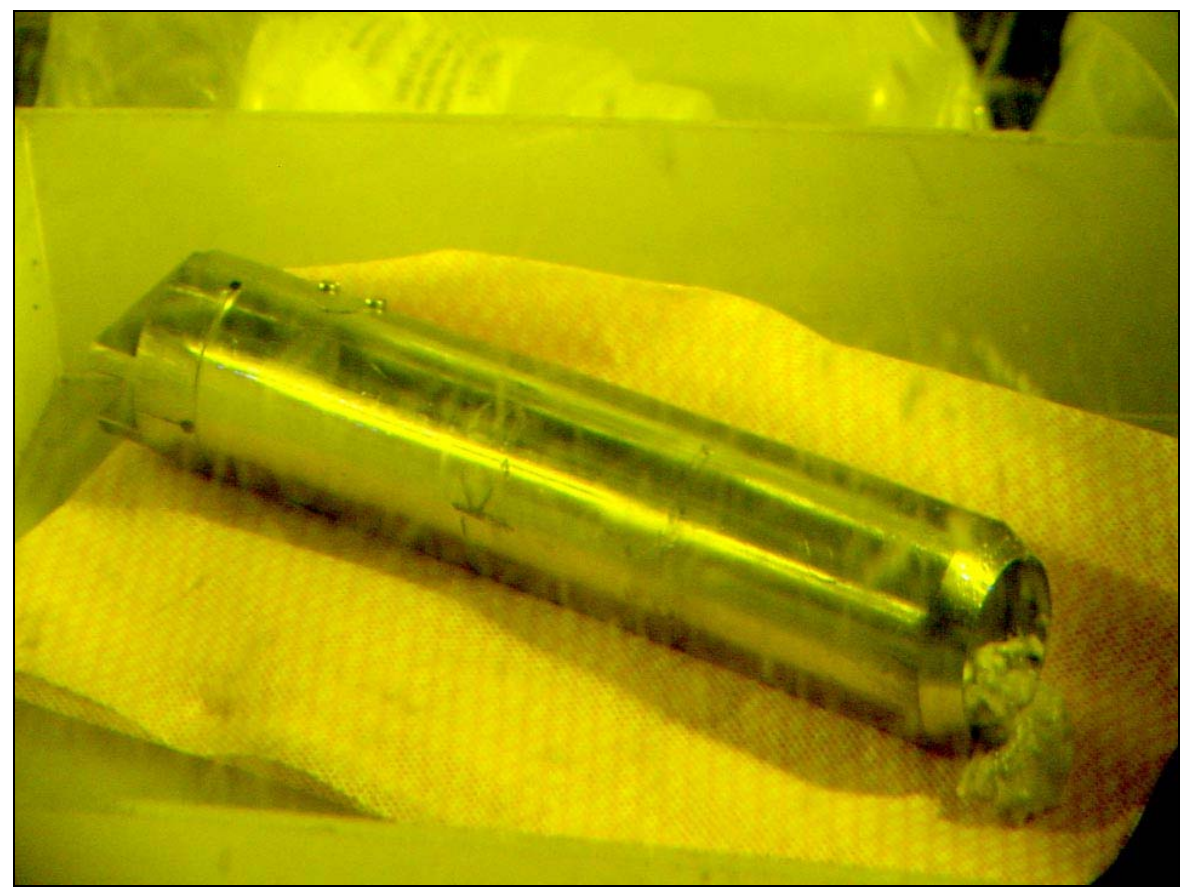

Figure 1: Tank 31H Salt Sample HTK-513.

The saltcake sample was medium to light gray/brown. The portion of the sample at the open sampler bottom, outside of the retaining basket, was wetter in appearance than the hard-packed saltcake contained within the bulk of the sampler volume. The sample also contained a small portion of steel tape.

The sample was split into several glass jars, see Figure 3, and subsequently weighed. The sample portions were combined, crushed, and stirred. This composite Tank $31 \mathrm{H}$ saltcake sample weighed $319 \mathrm{~g}$, with an additional 51 grams of material that was stored separately because it was potentially cross-contaminated during sample opening. 




Figure 2: Interior of Tank 31H Salt Sample HTK-513.

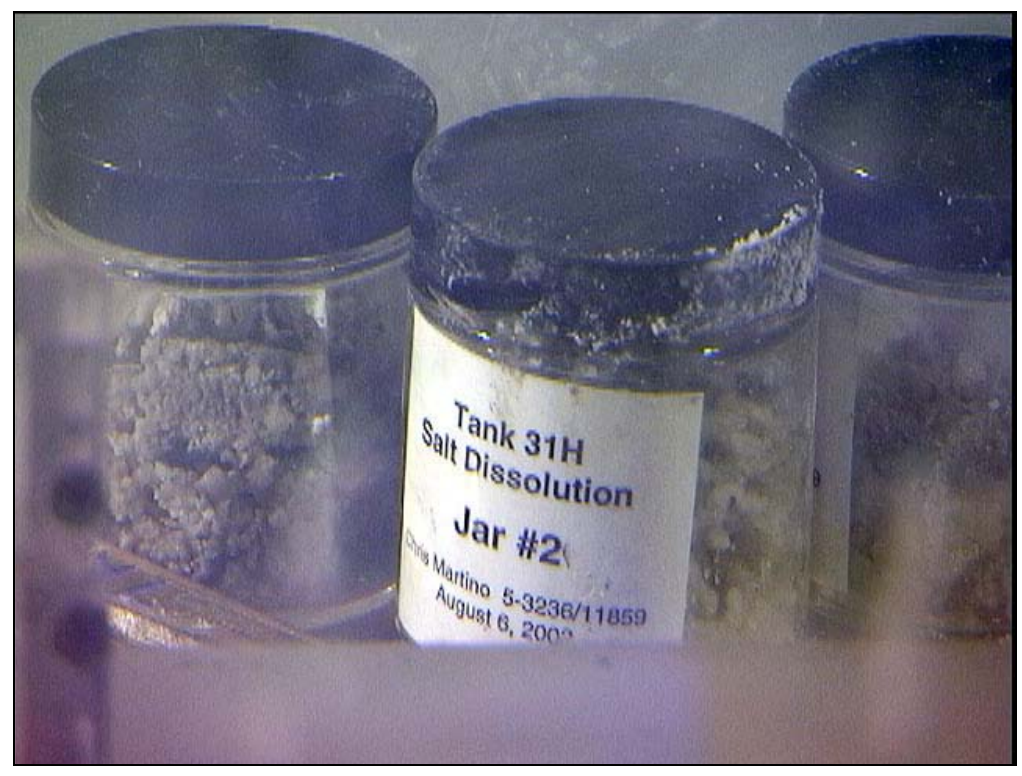

Figure 3: Jars of Tank 31H Saltcake from Sample HTK-513.

\section{Experimental}

The experimental approach is outlined in the task technical and quality assurance plan. ${ }^{10}$ The tests were modified from the salt dissolution simulant tests performed at SRS and the actual waste salt dissolution tests performed at Hanford. ${ }^{9,8}$ The multiple-wash test protocol involved contacting actualwaste saltcake with a series of aliquots of dissolution fluid. In contrast with expected full-scale salt dissolution conditions, these tests have relatively close approaches to equilibrium and better mixing. 
WSRC-TR-2002-00388

Revision 0

\section{Dissolution Test Protocol}

Two multiple-wash salt dissolution tests were performed on portions of the Tank $31 \mathrm{H}$ saltcake sample (HTK-513) in the SRTC Shielded Cells, Cell 14. The tests were performed concurrently using two different dissolution fluids (also referred to as diluents). The baseline dissolution fluid, as used in simulant testing, was inhibited water (IW). The IW was prepared from deionized water by the addition of $0.01 \mathrm{M} \mathrm{NaOH}$ and $0.011 \mathrm{M} \mathrm{NaNO}_{2}$. The alternative dissolution fluid was a composite of actual waste "HLW Supernate" from Tanks $21 \mathrm{H}, 24 \mathrm{H}$, and $26 \mathrm{~F}$. The composition of the HLW Supernate fluid was determined by the characterization to be a moderately concentrated supernate $\left(5.2 \mathrm{M} \mathrm{Na}^{+}\right.$, $\left.3.4 \mathrm{M} \mathrm{OH}^{-}\right)$.

Figure 4 contains a schematic of the multiple-wash dissolution protocol. For each test, a $60-\mathrm{g}$ portion of saltcake was added to a $50-\mathrm{mL}$ centrifuge tube and an aliquot of dissolution fluid was added. Over several hours, the tube was shaken briefly with the manipulator and mixed for short periods with a vortex mixer. After a minimum of 4 hours since the addition of the diluent, the tube was centrifuged to a constant volume of solids. The supernatant fluid was decanted and retained. This washing process was repeated ten times, with each wash contacting the remaining solids with an additional aliquot of diluent. The tests deviated from the ratios of cumulative diluent mass to original saltcake mass shown in Figure 4 as required for optimization. The initial washing steps used 7 to $7.5 \mathrm{~g}$ of diluent and the later steps used up to $45 \mathrm{~g}$ of diluent. Actual test conditions are reported with the results.

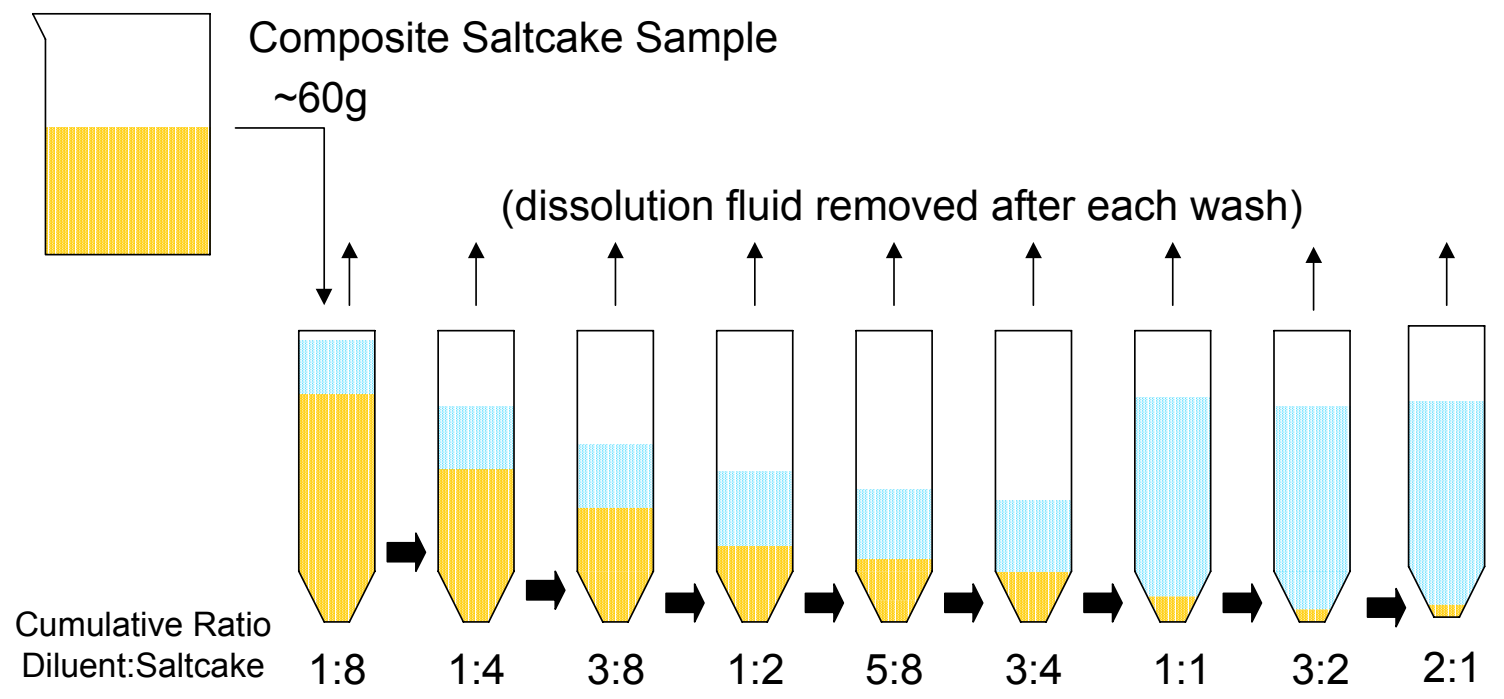

Figure 4: Multiple-Wash Dissolution Test.

These test were performed at ambient cell temperature, which during mid-to-late August was nominally $30^{\circ} \mathrm{C}$. Temperatures slightly higher, possibly up to $35^{\circ} \mathrm{C}$, were experienced during the centrifugal separation operation, and lower temperatures were likely experienced in the morning hours.

\section{Physical Dissolution Measurements}

Physical characterization of the saltcake, the decanted supernate, and the insoluble solids were performed in the shielded cells. The process centrifuge tubes were weighed before and after the addition and removal of material, and solid and liquid volume levels were recorded at key points in the washing cycles. This allowed for the estimation of the density of both the initial Tank $31 \mathrm{H}$ saltcake sample and the remaining undissolved solids (centrifuged and saturated with interstitial liquid). The densities of the decanted supernates and the three caustic fluids were determined gravimetrically at 
cell temperature using $2 \mathrm{~mL}$ volumetric flasks. Six portions of the as-received saltcake sample were dried at $115^{\circ} \mathrm{C}$ to determine the percent total solids.

\section{Chemical Sample Analysis}

Portions of the decanted dissolved salt supernate were diluted with $0.015 \mathrm{M} \mathrm{NaOH}$ for removal from the shielded cells and sent to the Analytical Development Section (ADS) for analysis. In-cell gamma counting was used to determine the level of dilution that each supernate fluid sample required.

After drying, portions of the residual insoluble solid remaining after each test were dissolved in duplicate using an acid dissolution process and submitted to ADS for analysis. The microwave acid dissolution process was performed within the Shielded Cells and was similar to the aqua regia dissolution (heating with nitric acid and hydrochloric acid) with an additional initial dissolution with hydrofluoric acid and an additional uptake with boric acid. The acid dissolution consumed $0.25 \mathrm{~g}$ of solids into $100 \mathrm{~mL}$ of solution.

The initial Tank $31 \mathrm{H}$ saltcake was characterized by two methods: (1) a triplicate analysis of 1-g portions of the salt dissolved in $50 \mathrm{~g}$ of $0.015 \mathrm{M} \mathrm{NaOH}$ and (2) a single analysis of an acid dissolution. The HLW supernate solution was also characterized by the same two methods, but using two to five times more material per dissolution than for the salt characterization.

Salt dissolution samples were submitted to ADS for the following analyses. An elemental analysis of the samples was provided by inductively coupled plasma - emission spectroscopy (ICP-ES). The primary use of the ICP-ES information was for determining the concentration of the cations, such as $\mathrm{Na}^{+}$and $\mathrm{K}^{+}$. This information was also used in determining the concentrations of several of the anions, including $\mathrm{Al}(\mathrm{OH})_{4}^{-}, \mathrm{SO}_{4}{ }^{2-}, \mathrm{PO}_{4}{ }^{3-}, \mathrm{MoO}_{4}{ }^{2-}, \mathrm{CrO}_{4}{ }^{2-}$, and $\mathrm{SiO}_{3}{ }^{2-}$. A wet chemical titration method was used to measure the total base, the free hydroxide, and the $\mathrm{CO}_{3}{ }^{2-}$ ion. Ion chromatography (IC) was used to analyze for the remainder of the applicable anions. Inductively coupled plasma - mass spectroscopy was used to quantify certain actinides and fission products. Gamma counting was used for ${ }^{137} \mathrm{Cs}$, and a separation and counting process was used for ${ }^{90} \mathrm{Sr}$. A special analysis was also performed to measure ${ }^{125} \mathrm{Sb}$ and ${ }^{126} \mathrm{Sn}$ for select samples. Acid dissolution samples were submitted to ADS for all the above analyses except IC Anions and Wet Chemistry. Samples of the dried residual solids were also analyzed by X-ray diffraction (XRD).

\section{Results and Discussion}

\section{As-Received Tank 31H Salt Characterization}

As-received Tank $31 \mathrm{H}$ saltcake was dissolved in inhibited water and in acid, and the results of the ionic composition analysis are presented in Table 1. Additional data obtained for the initial salt characterization are contained in the Appendix in Table 13. Table 1 also contains salt ion information obtained for the salt criticality samples from Tanks $41 \mathrm{H}$ and $37 \mathrm{H}$. The Tank $41 \mathrm{H}$ sample (HTF-E-173) was obtained from a well mined with water to near the bottom of the tank. The Tank $41 \mathrm{H}$ formulation contains ionic composition of the water-soluble portion of the saltcake based on the washwater analysis, which was not originally reported in the sample analysis report. ${ }^{3}$ The Tank $37 \mathrm{H}$ samples HTF-426 and 427) were obtained in a manner similar to the Tank $31 \mathrm{H}$ sample, by pounding the sampler into the surface of the saltcake. The characterization of the soluble portion of a composite of the Tank $37 \mathrm{H}$ material is reported for a water dissolution of the sample, which was not previously reported with the acid dissolution data. ${ }^{11}$ Methods used for the analysis of water dissolutions of Tank $41 \mathrm{H}$ and Tank $37 \mathrm{H}$ salt are similar to those used for the Tank $31 \mathrm{H}$ salt. The aluminum and silicon concentrations reported for the Tank $37 \mathrm{H}$ saltcake are based on their results from an acid dissolution. Values in Table 1 proceeded by " $<$ " were present in the dissolution at a concentration less than the 
minimum detection limit. The averages and standard deviations are reported in Table 1 are the result of three measurements for the water dissolutions of Tank $31 \mathrm{H}$ and Tank $37 \mathrm{H}$ material and two measurements for water dissolution of Tank $41 \mathrm{H}$ material. No standard deviation is reported for the acid dissolution of Tank $31 \mathrm{H}$ material because it was performed only once.

These three saltcake samples from the H-Area Tank Farms of SRS have somewhat different compositions. All three saltcake samples were primarily sodium nitrate with smaller amounts of sodium nitrite and sodium hydroxide. A significant portion of the Tank $31 \mathrm{H}$ and Tank $41 \mathrm{H}$ samples were aluminum, approximately $13 \mathrm{wt} \%$ on a $\mathrm{Al}(\mathrm{OH})_{4}{ }^{-}$basis. This is in contrast with only $2.6 \mathrm{wt} \%$ $\mathrm{Al}(\mathrm{OH})_{4}{ }^{-}$for the Tank $37 \mathrm{H}$ saltcake. The three salt samples had amounts of carbonate, sulfate, and phosphate that varied within about an order of magnitude. Tank $31 \mathrm{H}$ contained the largest sulfate concentration and Tank $37 \mathrm{H}$ contained the least. Although Tank 37 was low in aluminate and sulfate, it contained the largest concentration of carbonate and phosphate. The Tank $31 \mathrm{H}$ saltcake sample on which this report focuses did not contain detectable levels of fluoride, chloride, and oxalate. Tank $37 \mathrm{H}$ saltcake was seen to have some chloride, and Tank $41 \mathrm{H}$ saltcake was seen to have chloride, oxalate, and formate.

Table 1: Ionic Composition of Tank 31H Saltcake, Compared With Tank 41H and 37H Salt.

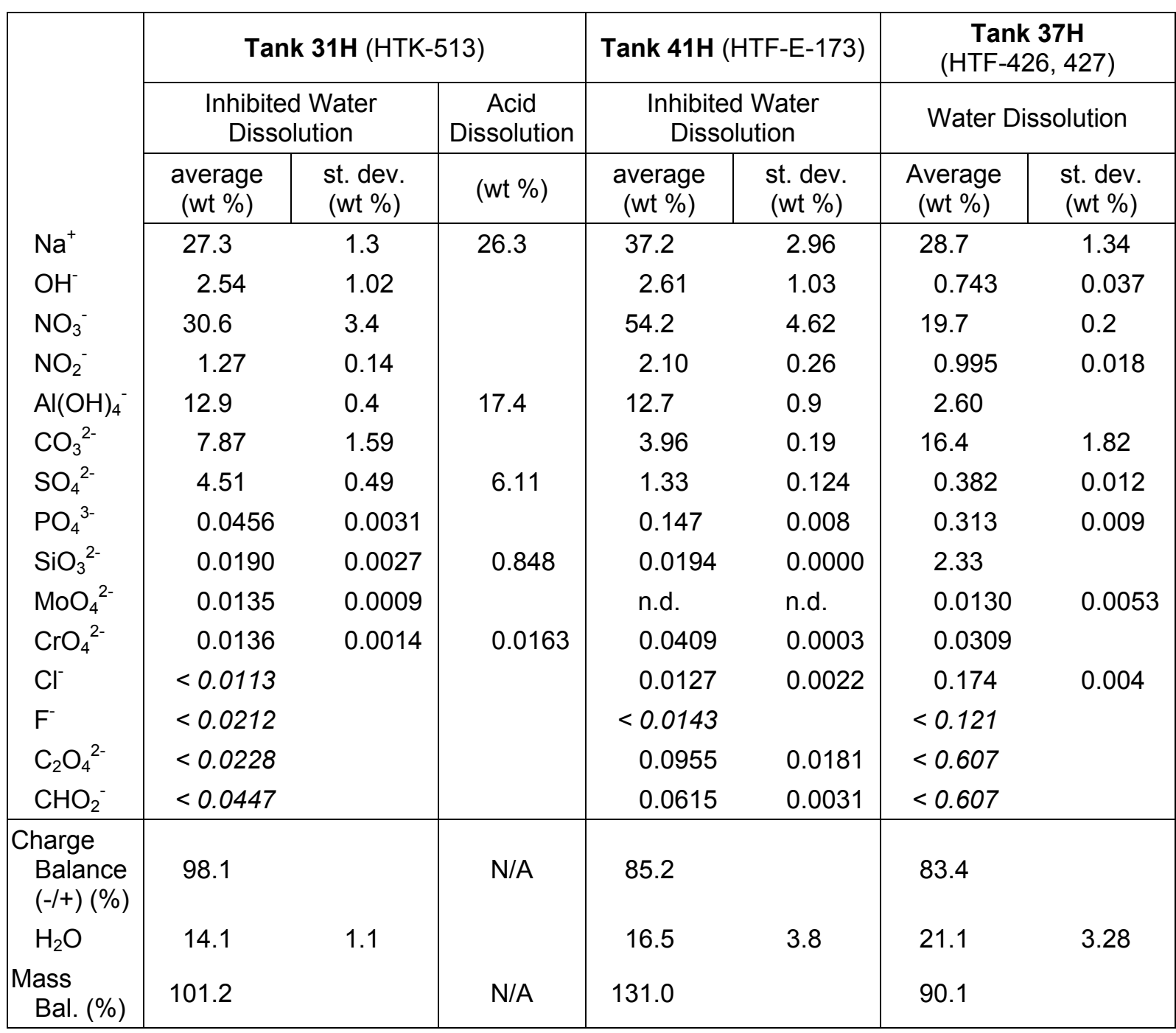


Table 1 also contains the percent moisture for each as-received saltcake. For the Tank $31 \mathrm{H}$ saltcake, this value is an average of six measurements. The values for the other saltcake are obtained from their respective reports. The -/+ Charge Balance is the percentage of measured sodium that can be accounted for by the measured anions. All of the charge balances were slightly below $100 \%$, signifying that more sodium was measured than the corresponding anions. A simulant recipe made from these unbalanced compositions, either a smaller amount of sodium or a larger amount of a major anion (i.e., nitrate) should be added. The mass balance is a sum of the weight percentages of the detectable salt components and water. Although the mass balance for the Tank $41 \mathrm{H}$ washwater analysis differed from $100 \%$ by more than the expected $10 \%$ experimental error, no single analysis or analyte was identified as the sole contributor to this deviation. Rather, this error was likely introduced to all analytes via a common error in a dilution factor. The mass balances for the Tank $31 \mathrm{H}$ and $37 \mathrm{H}$ salt closed within $10 \%$.

Table 2 contains the radiochemical analysis and ICP-MS analysis for radionuclides in the water dissolution and acid dissolution of Tank $31 \mathrm{H}$ saltcake. The cesium concentration was essentially the same in the water and acid dissolutions. This observation signifies that only a relatively small portion (difficult to quantify due to experimental uncertainty) of the initial ${ }^{137} \mathrm{Cs}$ may ultimately be contained within the water-insoluble solids resultant from saltcake dissolution. The initial saltcake characterization for strontium, uranium, and plutonium was significantly higher for the acid dissolution than for the water dissolution, indicating that there was a significant portion of those compounds that were only sparingly soluble in water. The fractional uranium enrichment reported for the acid dissolution of the saltcake are unreliable due to the ${ }^{235} \mathrm{U}$ measurement being very close to the minimum detectable level. Based on the most accurate values, the original saltcake was $0.00178 \mathrm{wt}$ $\%$ total uranium, with a ${ }^{235} \mathrm{U}$ enrichment $\left({ }^{235} \mathrm{U} / \mathrm{T}\right.$ otal $\left.\mathrm{U}\right)$ of $17.0 \mathrm{wt} \%$.

Table 2: Radionuclides in As-Received Tank 31H Saltcake

\begin{tabular}{|c|c|c|c|}
\hline & \multicolumn{2}{|c|}{ Inhibited Water Dissolution } & \multirow{2}{*}{ Acid Dissolution } \\
\hline & Average & St. Dev. & \\
\hline \multicolumn{4}{|c|}{ Rad Chem $(\mu \mathrm{Ci} / \mathrm{g})$} \\
\hline${ }^{137} \mathrm{Cs}$ & 388 & 35 & 396 \\
\hline${ }^{90} \mathrm{Sr}$ & 9.33 & 1.26 & 5.39 \\
\hline \multicolumn{4}{|c|}{ ICP-MS (wt\%) } \\
\hline${ }^{99} \mathrm{Tc}$ & 5.56E-04 & $2.9 \mathrm{E}-05$ & 1.07E-03 \\
\hline${ }^{233} U$ & $<1.04 E-05$ & & $<1.06 E-04$ \\
\hline${ }^{234} U$ & $<1.04 E-05$ & & $<1.06 E-04$ \\
\hline${ }^{235} U$ & 5.63E-05 & $1.43 \mathrm{E}-05$ & $1.57 \mathrm{E}-04$ \\
\hline${ }^{236} U$ & 2.63E-05 & 4.5E-06 & $<1.06 E-04$ \\
\hline${ }^{237} \mathrm{~Np}$ & $<1.04 E-05$ & & $<1.06 E-04$ \\
\hline${ }^{238} U$ & $2.45 E-04$ & $3.8 \mathrm{E}-05$ & $1.62 \mathrm{E}-03$ \\
\hline${ }^{239} \mathrm{Pu}$ & $<1.04 E-05$ & & $<1.06 E-04$ \\
\hline Total U & $3.28 \mathrm{E}-04$ & 5.6E-05 & $1.78 \mathrm{E}-03$ \\
\hline $\begin{array}{l}{ }^{235} \mathrm{U} / \text { Total U U } \\
\text { (wt.frac.) }\end{array}$ & 0.170 & 0.015 & 0.088 \\
\hline
\end{tabular}




\section{HLW Supernate Characterization}

The alternate dissolution fluid is referred to in this document as HLW Supernate (from Tanks $21 \mathrm{H} / 24 \mathrm{H} / 26 \mathrm{~F}$ ). The fluid is a composite of unused ( 5 to $20 \mathrm{~mL}$ ) portions of filtrate from several evaporator-feed qualification characterizations performed during 2002. The variable depth samples that contributed to this composite supernate are as follows: HTF-465, 466, and 467 (from Tank 21H); HTK-473 and 474 (from Tank 24H); FTF-042, 043, and 044 (from Tank 26F); and FTF-089, 090, and 091 (from Tank 26F). The analysis results of the individual samples are provided elsewhere. ${ }^{12,13,14}$

The HLW Supernate composite sample contained a small amount of brown/orange solids. The density of the fluid was determined to be $1.278 \mathrm{~g} / \mathrm{cm}^{3}$. The supernate was prepared for analysis by two methods: dilution in $0.015 \mathrm{M} \mathrm{NaOH}$ and dissolution by $\mathrm{HF} / \mathrm{HNO}_{3} / \mathrm{HCl}$. Table 3 contains a summary of the HLW Supernate composite characterization (see Appendix Table 14 for additional

Table 3: Summary of HLW Supernate Characterization (from Tanks 21H/24H/26F)

\begin{tabular}{|c|c|c|c|c|}
\hline & \multicolumn{2}{|c|}{ Inhibited Water Dilution } & \multicolumn{2}{|c|}{ Acid Dissolution } \\
\hline & average (M) & st. dev. (M) & & (M) \\
\hline $\mathrm{Na}^{+}$ & 5.19 & 0.05 & & 6.50 \\
\hline $\mathrm{K}^{+}$ & 0.0312 & 0.0005 & & 0.0438 \\
\hline $\mathrm{OH}^{-}$ & 3.41 & 0.10 & & \\
\hline $\mathrm{NO}_{3}^{-}$ & 0.779 & 0.044 & & \\
\hline $\mathrm{NO}_{2}^{-}$ & 0.764 & 0.049 & & \\
\hline $\mathrm{Al}(\mathrm{OH})_{4}^{-}$ & 0.202 & 0.005 & & 0.245 \\
\hline $\mathrm{SO}_{4}^{2-}$ & 0.0150 & 0.0003 & & 0.0283 \\
\hline $\mathrm{PO}_{4}^{3-}$ & $3.58 \mathrm{E}-03$ & 2.1E-04 & & 4.17E-03 \\
\hline $\mathrm{SiO}_{3}{ }^{2-}$ & $1.11 \mathrm{E}-03$ & $2 \mathrm{E}-05$ & $\mathrm{Si}$ & 5.69E-03 \\
\hline $\mathrm{MoO}_{4}{ }^{2-}$ & $5.00 \mathrm{E}-04$ & $6 \mathrm{E}-06$ & & $6.74 \mathrm{E}-04$ \\
\hline $\mathrm{CrO}_{4}^{2-}$ & 2.47E-03 & $5 \mathrm{E}-05$ & & $3.12 \mathrm{E}-03$ \\
\hline $\begin{array}{l}\text { Charge } \\
\text { Balance (\%) }\end{array}$ & 100.4 & & & \\
\hline & Average (M) & st. dev. (M) & & (M) \\
\hline B & $1.34 \mathrm{E}-02$ & 3E-04 & & \\
\hline $\mathrm{Ce}$ & 5.01E-05 & 3.6E-06 & & 8.66E-05 \\
\hline $\mathrm{Cu}$ & $1.66 \mathrm{E}-04$ & 4E-06 & & 2.61E-04 \\
\hline $\mathrm{Fe}$ & $2.86 \mathrm{E}-04$ & 3.3E-05 & & $9.13 \mathrm{E}-04$ \\
\hline $\mathrm{Mn}$ & $1.40 \mathrm{E}-05$ & $1.9 \mathrm{E}-06$ & & 4.30E-05 \\
\hline $\mathrm{Sn}$ & $1.33 \mathrm{E}-04$ & $2.8 \mathrm{E}-05$ & & 2.63E-03 \\
\hline \multirow[t]{3}{*}{$\mathrm{Zn}$} & $1.88 \mathrm{E}-04$ & 7E-06 & & 1.69E-04 \\
\hline & & & $\mathrm{Mg}$ & $1.48 \mathrm{E}-04$ \\
\hline & & & $\mathrm{Zr}$ & $6.42 \mathrm{E}-04$ \\
\hline & $\begin{array}{c}\text { average } \\
\text { (Ci/gal) }\end{array}$ & $\begin{array}{l}\text { st. dev. } \\
\text { (Ci/gal) }\end{array}$ & & \\
\hline${ }^{137} \mathrm{Cs}$ & 2.75 & 0.19 & & \\
\hline${ }^{90} \mathrm{Sr}$ & 2.18E-04 & 1.3E-05 & & \\
\hline
\end{tabular}


results). The averages and standard deviations for the analysis of three water dissolutions are reported, as well as the value from a single acid dissolution. The results from the acid dissolution were consistently $20 \%$ to $40 \%$ greater than those from the inhibited water dilution. This does not indicate that a large fraction of material was insoluble for all components, but rather it is likely that the acid dissolution result is biased high. There are several components that were not completely soluble in inhibited water and displayed a much greater concentration from the acid dissolution, including silicon and iron.

This alternate fluid provides data that demonstrates the effect of the ionic strength and hydroxide concentration of the diluent on saltcake dissolution. This moderately concentrated HLW Supernate (5.2 $\mathrm{M} \mathrm{Na}^{+}, 3.4 \mathrm{M} \mathrm{OH}^{-}$) is likely above the upper bound for sodium and hydroxide concentration that SRS engineers would recommend for the intentional dissolution of saltcake.

\section{$\underline{\text { Visual Observations }}$}

The multiple-wash dissolution tests with IW and with HLW Supernate were performed concurrently in the Shielded Cells. Figure 5 and Figure 6 show the progress of the dissolution for one of the earlier stages of the dissolution. The left picture in Figure 5 shows how the salt slurry was shaken in the centrifuge tube periodically during the $>4$ hour of equilibration time. On occasions when the salt was packed into the centrifuge tube cone and could not be slurried by shaking, the tube was opened and the material at the bottom was suspended by stirring with a spatula. The mixed and equilibrated slurry was subsequently centrifuged to a constant solid-fraction volume for two to three periods of 15 minutes. Figure 6 shows the intermediate progress of the multiple-wash dissolution with IW and HLW Supernate. The dissolved salt supernate was successfully clarified by centrifuging, but it had a yellow color. The liquid was decanted from each centrifuge tube, as seen in the right picture in Figure 5, and subsequently diluted and analyzed.
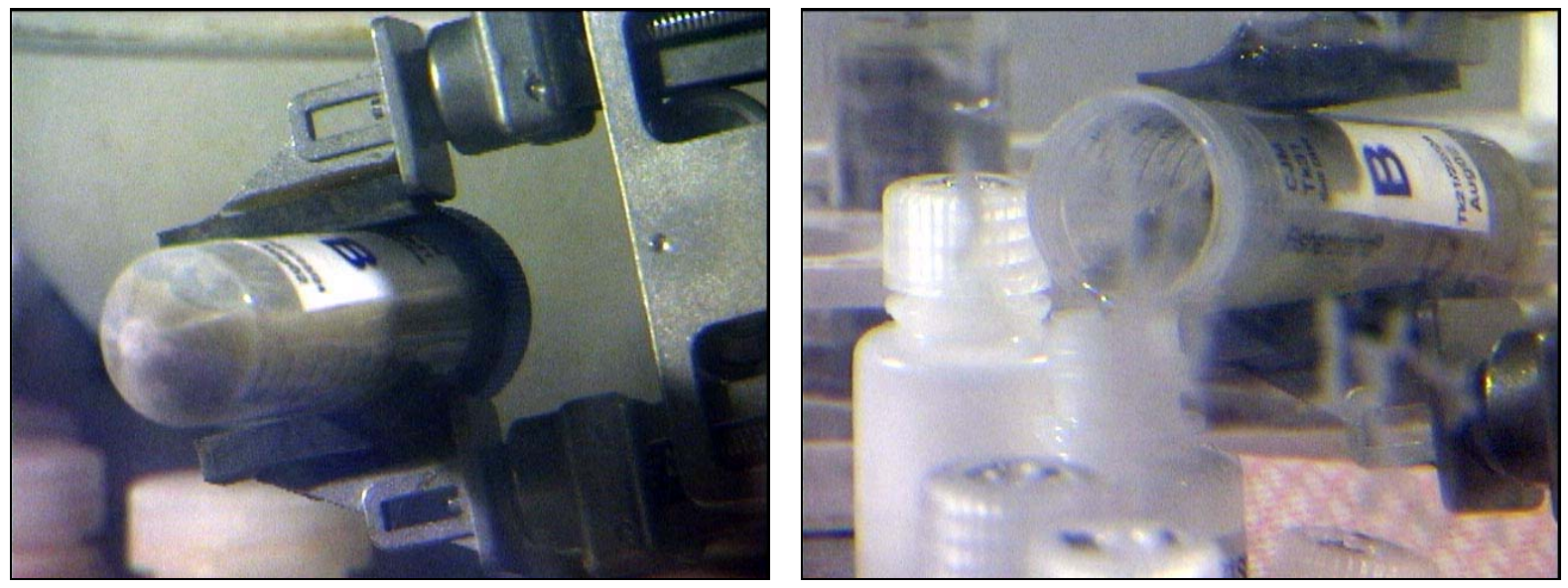

Figure 5: Tank 31H Salt Dissolution With HLW Supernate Material, Mixing Step (Left) and Decanting Step (Right) of the Second Wash. 
Revision 0

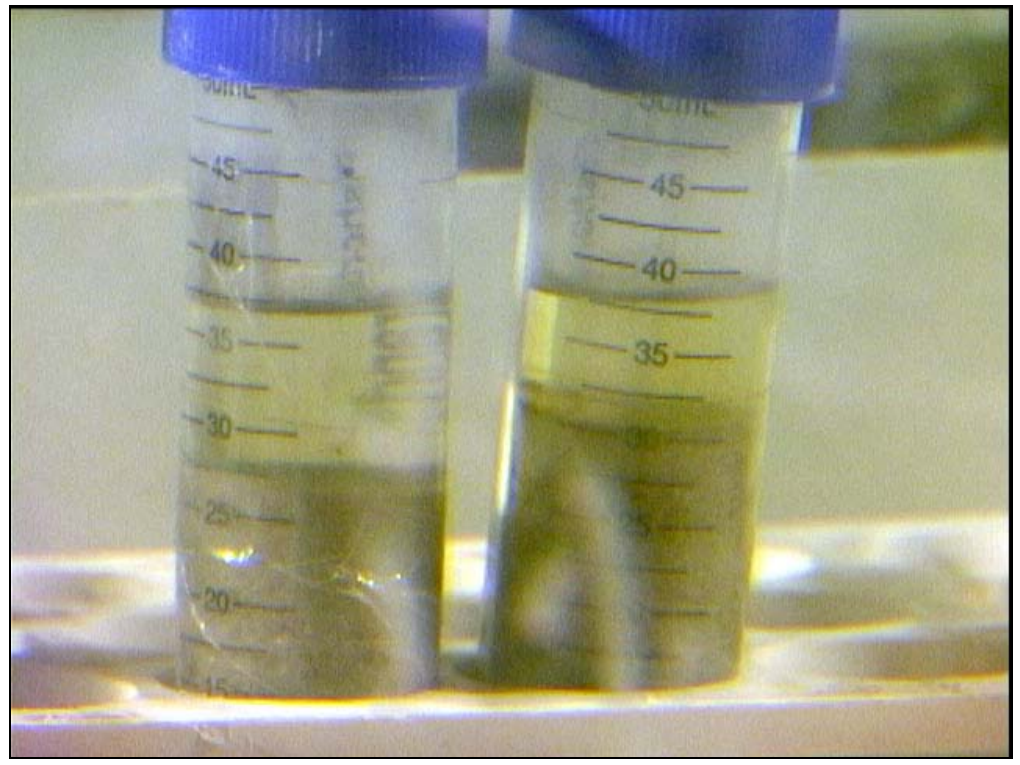

Figure 6: Clarified Supernate and Residual Salt after the Second Wash Using Inhibited Water (Left) and HLW Supernate (Right).

During the eighth through tenth dissolution steps, there was little change in the appearance and quantity of residual solid material from the dissolution with IW. Thus, it was evident that most of the IW-soluble material had been removed. The dissolution with HLW Supernate, however, appeared to be incomplete by the tenth wash, when the available supply of HLW Supernate material had been exhausted. Figure 7 shows the insoluble material that remained after centrifuging during the tenth dissolution step. The clarified supernate from this stage of the IW dissolution was colorless, while the supernate from the HLW Supernate dissolution was yellow. The wet insoluble material resulting from dissolution with IW was about $2 \mathrm{~mL}$ of fine medium-gray solids. The material from dissolution with HLW supernate was about $6 \mathrm{~mL}$ of white/clear salt crystals and gray/brown solids. The material resulting from the last step of dissolution with HLW Supernate would have dissolved further if more diluent had been applied.
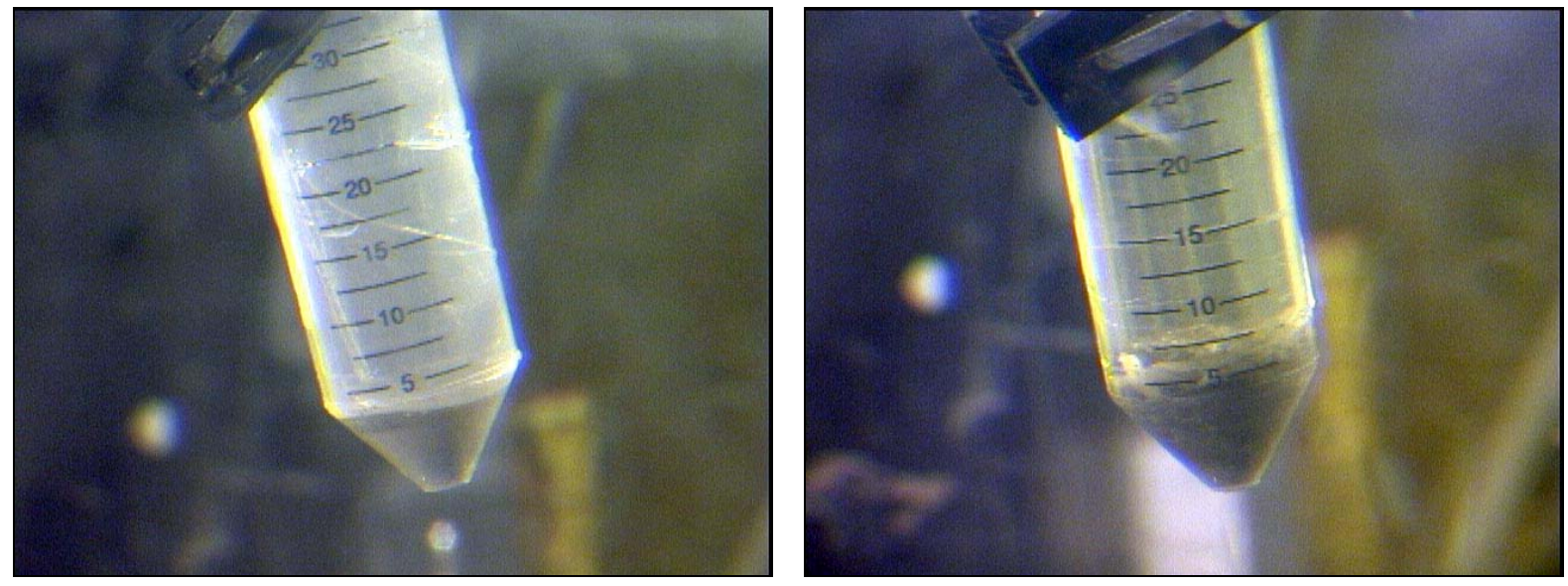

Figure 7: Residual Insoluble Solids Resultant from Salt Dissolution using Inhibited Water (Left) and HLW Supernate (Right). 


\section{Physical Data}

Figure 8 and Figure 9 contain some of the trends in the physical data collected for the saltcake dissolution of Tank $31 \mathrm{H}$. The physical data are plotted versus the cumulative mass of dissolution fluid normalized by the mass of original saltcake.

Figure 8 displays the mass fraction of saltcake remaining during the progressive multiple-wash dissolution of Tank $31 \mathrm{H}$ saltcake with IW and HLW supernate. Figure 8 also provides for comparison the analogous data from the dissolution of simulated SRS saltcake with IW at 25 and $50{ }^{\circ} \mathrm{C}$. The dissolution of the actual-waste saltcake at Shielded Cells temperatures $\left(\sim 30^{\circ} \mathrm{C}\right)$ required a similar amount of IW as did the Average SRS simulant saltcake at $25^{\circ} \mathrm{C}$. The actual-waste saltcake, however, was seen to have a greater fraction of insoluble material at the end of the test than did the simulated saltcake. The dissolution with HLW Supernate also displayed a steady decrease in the fraction of material remaining undissolved as more diluent was used. It required at least three times as much $5.2 \mathrm{M} \mathrm{Na}^{+} \mathrm{HLW}$ Supernate material than IW to dissolve a comparable amount of saltcake material. Although the analyses reported later do show that some components of the Tank $31 \mathrm{H}$ salt material were dissolved or eluted, the saltcake mass increased with the addition and removal of the first batch of HLW Supernate. The increase in saltcake mass during this initial HLW supernate addition was likely due to the rewetting of the salt and the filling of the partially filled pores. This phenomenon is not noticed for the first stage of dissolution with IW because a significant amount of dissolution is taking place and obscuring the effects of salt rewetting.

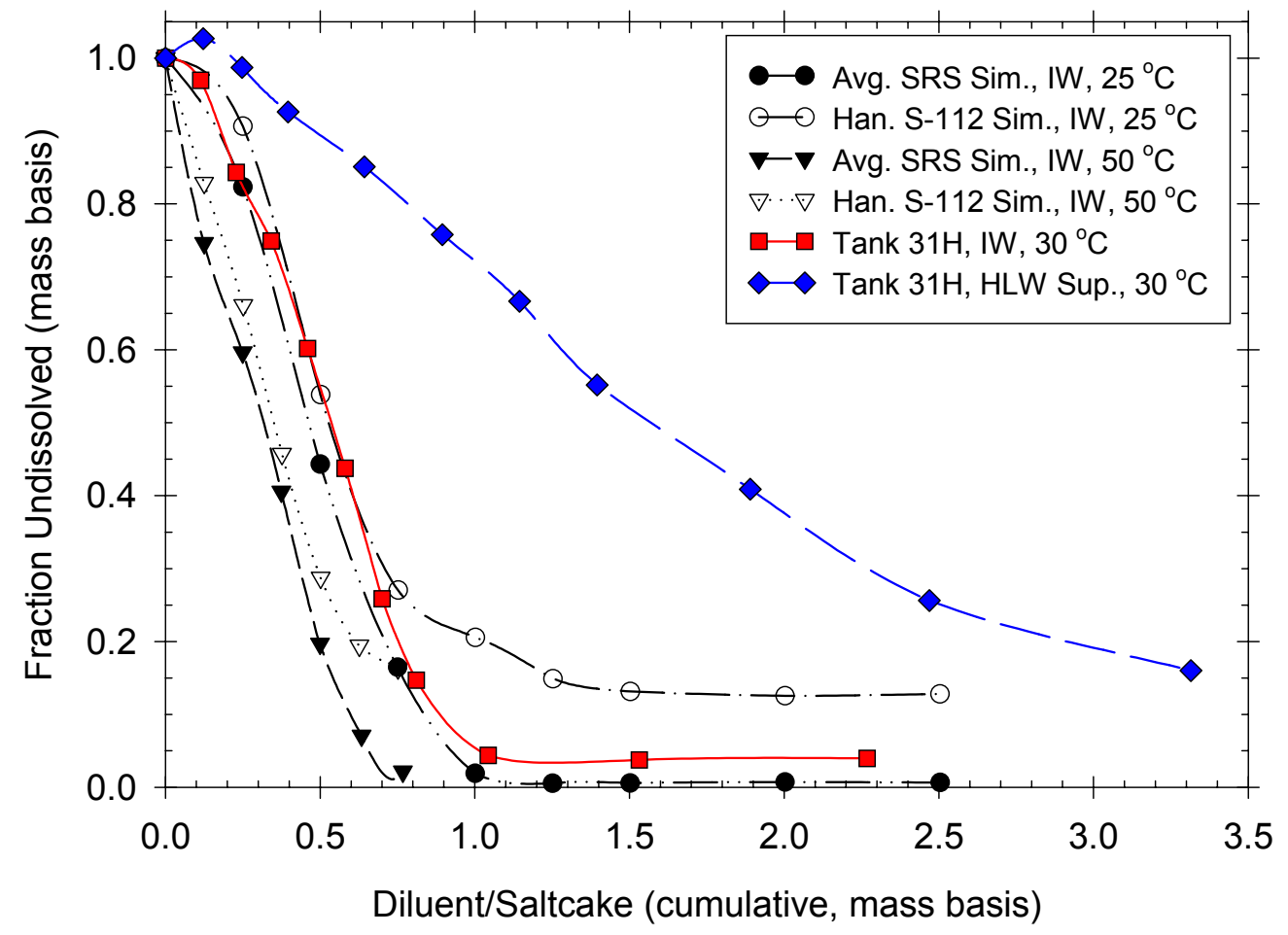

Figure 8: Mass Fraction of Saltcake Remaining Undissolved During Multiple-Wash Dissolution Tests. Includes Actual-Waste Tests of Dissolution of Tank 31H Salt With Inhibited Water and HLW Supernate Compared With Previous Tests with Simulant Saltcake.

Figure 9 tracks the density, or specific gravity (SpG), of the supernatant liquors removed from the multiple-wash tests with Tank $31 \mathrm{H}$ saltcake and SRS simulated saltcake. During the initial stages of dissolution of Tank $31 \mathrm{H}$ saltcake, the equilibrium SpG for the supernatant fluid created by contact with both dissolution fluids was roughly 1.45 . The data for the early stages of actual-waste saltcake 
dissolution at $30^{\circ} \mathrm{C}$ compare well with the dissolution of simulated saltcake at $25^{\circ} \mathrm{C}$. The completion of dissolution is indicated by the density of the decanted supernate approaching the density of the dissolution fluid. Additional physical data (the approximate solid-phase density and the percent total solids in the supernatant liquid and residual solid) are contained in the Appendix.

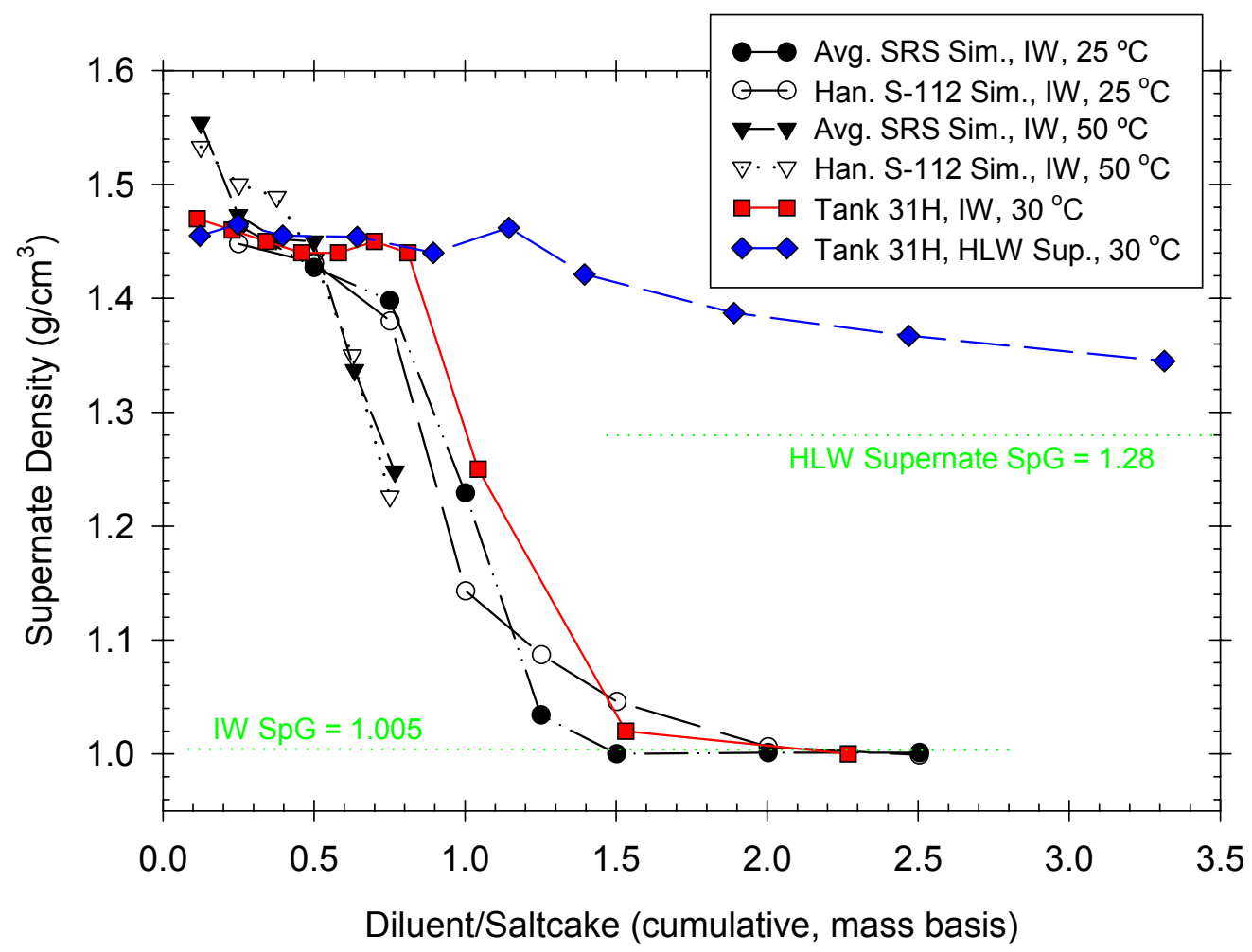

Figure 9: Densities of Supernatant Liquids Decanted During Multiple-Wash Dissolution Tests. Includes Actual-Waste Tests of Dissolution of Tank 31H Salt With Inhibited Water and HLW Supernate Compared With Previous Tests with Simulant Saltcake.

\section{Dissolution with Inhibited Water}

The top portion of Table 6 in the Appendix contains the test data for the salt dissolution test using inhibited water as the dissolution fluid. Diluent/Saltcake is the cumulative mass of inhibited water added per the $60.764 \mathrm{~g}$ of original Tank $31 \mathrm{H}$ saltcake. This ratio is the abscissa of most of the data plots and it can be used to calculate the mass of diluent added during each wash. Supernate Removed is the grams of clear supernate removed from the tube after mixing and centrifuging. It includes the inhibited water added plus any dissolved salt and interstitial liquid that could be poured from the tube. The volume percentage reported as Supernate is the volume percent of clear liquid in the centrifuge tube that is above the solid-supernate interface after mixing and centrifuging for each washing step (non-cumulative). The volume percentage of wet solids for each washing step can be calculated as $100 \%$ minus this Supernate value. This value can also be used to estimate the bulk density of the supernate and residual solid. Undissolved Salt is the weight percentage of the original $60.764 \mathrm{~g}$ of salt that remains in the tube after decanting the supernatant liquid. At the end of the test, this represents the weight percentage of wet residual insoluble solids resultant from salt dissolution. Supernatant Density is the specific gravity of the supernate decanted from the tube for each washing step. Charge Balance $(-/+)$ is defined as the percentage of measured cations (sodium and potassium) that can be accounted for by the measured anions (by IC Anions and Wet Chemistry, and 
estimated from ICP-ES). A charge balance under $100 \%$ signifies an anion deficiency, while a charge balance over $100 \%$ signifies an anion surplus.

Table 6 also contains the ICP-ES data for the ten solutions decanted from the multiple-wash dissolution of Tank $31 \mathrm{H}$ saltcake with IW, plus duplicate analyses of samples from the second and fourth dissolution stages. Table 7 contains the analogous data obtained from the IC Anions, Wet Chemistry, Rad. Chemistry, and ICP-MS analyses. For compounds that were not detected in the diluted ADS samples at concentrations above their minimum detection limit, the adjusted detection limit is reported preceded by "<". The hydroxide results in Table 7 are adjusted for the hydroxide in the sample dilution fluid $(0.015 \mathrm{M})$. Two values are reported in the hydroxide concentration: the measured result adjusted for dilution and a result calculated from the adjusted measurements of total base, aluminate, and carbonate. The calculated Free $\mathrm{OH}$ value is used in this analysis because it was more consistent than the measured value.

Figure 10 and Figure 11 are plots of the supernatant concentration of various components decanted during each stage of the multiple-wash dissolution, derived from Table 6 and Table 7. Figure 10 focuses on the sodium and anions. The initial seven dissolution stages, up to a diluent/saltcake value of 0.81 , had a nearly constant sodium concentration in the range of 8.8 to $9.6 \mathrm{M}$ that trended slightly downward. Nitrate was nearly constant with a slightly increasing trend over the first six dissolution stages, up to a diluent/saltcake value of 0.70 . Several of the saltcake components (nitrite, hydroxide, aluminate, phosphate, molybdate, and chromate) had their highest concentration in the first dissolution step and displayed a roughly exponential declines in concentration with the continued addition of dissolution fluid. This is characteristic of ions that are resident in the interstitial fluid of the original saltcake rather than in solid salt crystals. Conversely, nitrate, carbonate, and sulfate display the profile of compounds that are present in the salt at much greater than their solubility in the salt mixture. In general, the concentration of these components in the decanted supernate increases in subsequent washing batches. This increase continues until the point when the other salts have been depleted, after which time these less soluble salts become depleted.

Figure 11 displays how the activity of ${ }^{137} \mathrm{Cs}$ and ${ }^{90} \mathrm{Sr}$ changed throughout the dissolution process. The cesium concentration was highest in the first dissolution stage and had a roughly exponential decline in subsequent stages, which indicates its presence in the interstitial liquid rather than in the salt crystals. The portion of the strontium that dissolved during the tests did so in a narrow window when most of the salt had already been dissolved and was likely the result of $\mathrm{SrCO}_{3}$ dissolution.

Table 8 contains the mass of each compound that dissolved and was removed each dissolution step. This data was adjusted for the composition of nitrite and hydroxide in the IW dissolution fluid. The data reported for the second and fourth washes are averages of two analytical results. Phosphate and sulfate are calculated from the ICP-ES results rather than from the IC Anions results. In a column labeled "Total", Table 8 contains a sum of the mass of each component compiled from the ten dissolved salt fractions. The column labeled "Solids" contains the mass of each component contained in the residual insoluble solids, which is determined from the digestion and analysis of the material remaining after the tenth dissolution stage. The mass of several anions in the solid were not determined due to interference from the acid dissolution method.

Using the data in Table 8, the salt dissolution profiles of Figure 12 through Figure 14 were formed, relating the mass fraction of a saltcake component that dissolved and eluted with a cumulative mass of dissolution fluid used per mass of original saltcake. Figure 12 contains the profile for the dissolution and subsequent removal of the major saltcake components, including the sodium cation and several of the anions that were present in the largest quantities. The removal of aluminum as $\mathrm{AlO}_{2}{ }^{-}$and $\mathrm{Al}(\mathrm{OH})_{4}{ }^{-}$is reported as the removal of $\mathrm{Al}$. Figure 13 contains the minor elemental saltcake components measured with ICP-ES and Figure 14 contains the isotopes measured with ICP-MS and Radiochemical methods. By the eighth wash, the cumulative dissolution with 1.043:1 mass of IW:salt accomplished the removal of $>99 \%$ of the sodium in the original saltcake. The dissolution curve for sodium is provided in all figures as a reference. 


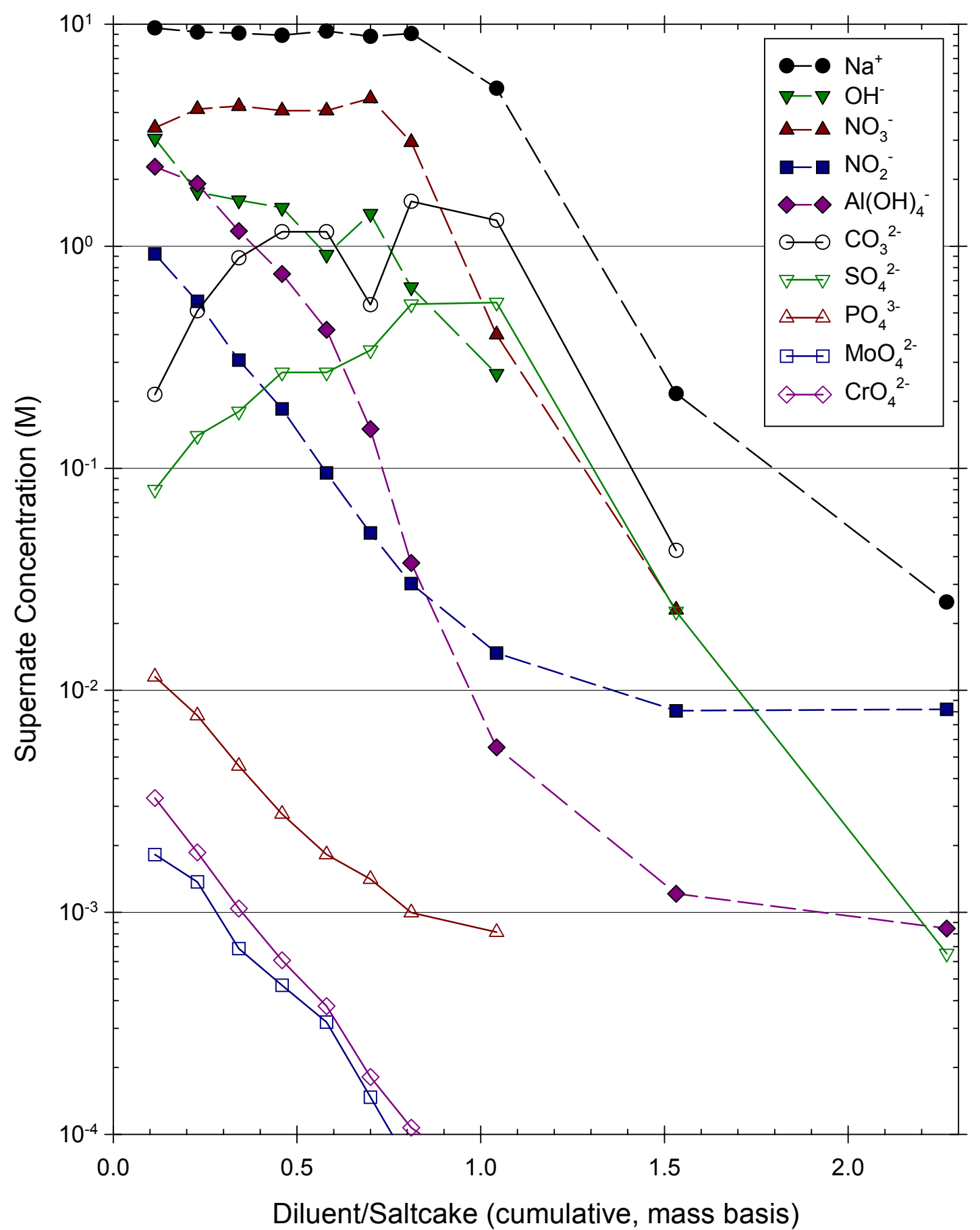

Figure 10: Supernate Composition for the Multiple-Wash Dissolution of Tank 31H Saltcake with Inhibited Water 


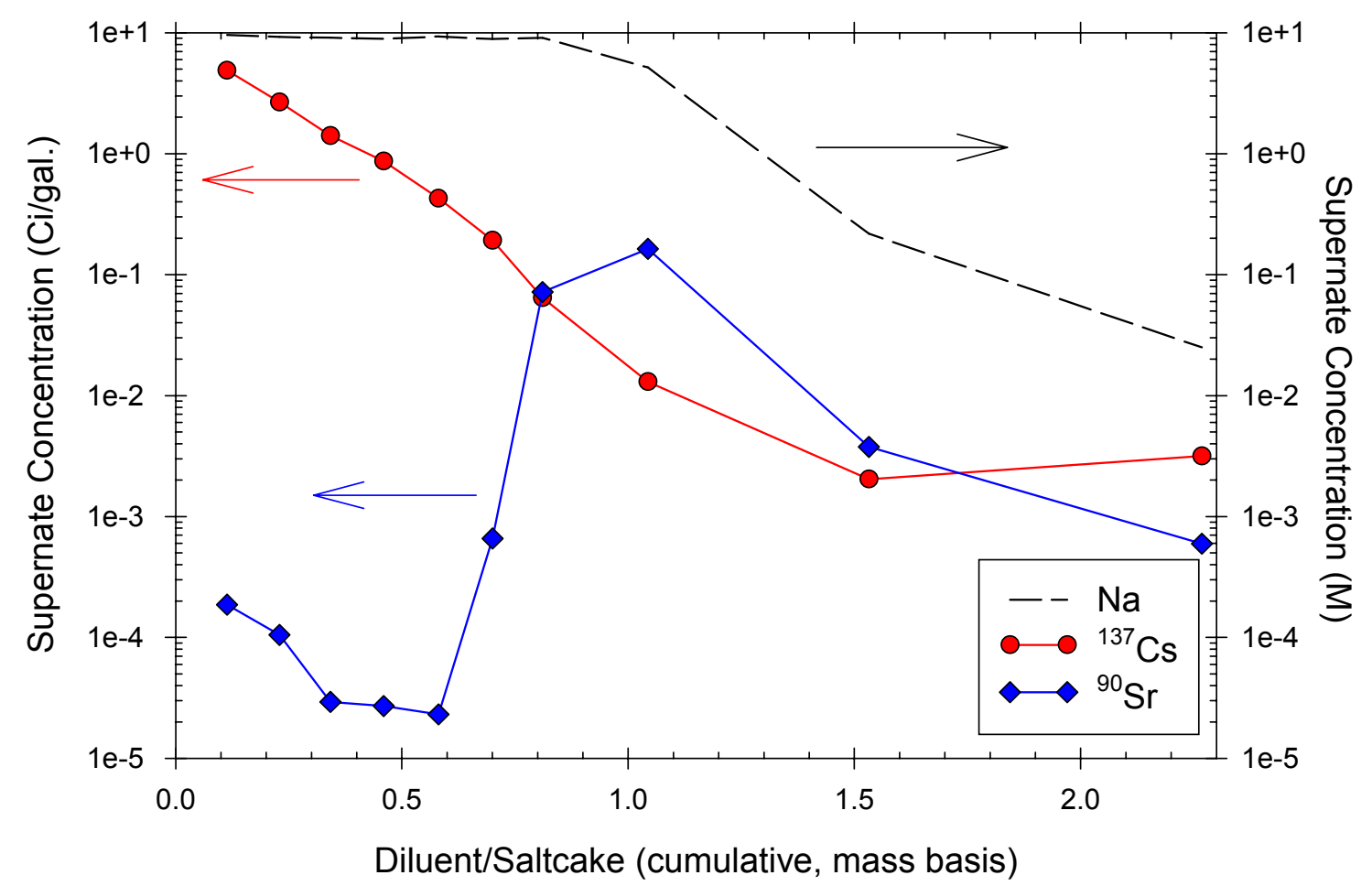

Figure 11: ${ }^{137} \mathrm{Cs}$ and ${ }^{90} \mathrm{Sr}$ Activity from the Multiple-Wash Dissolution of Tank $31 \mathrm{H}$ Saltcake with Inhibited Water

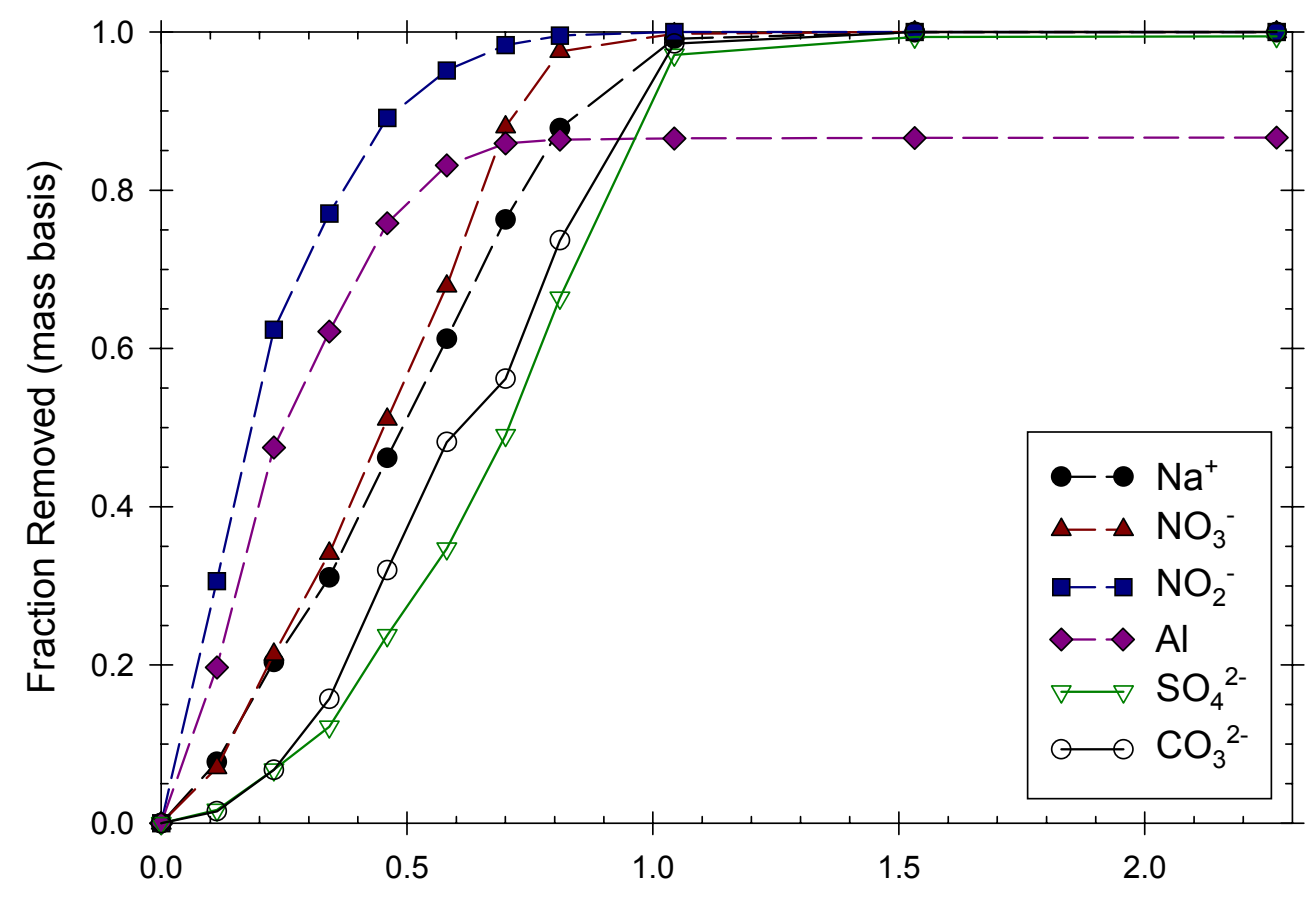

Diluent/Saltcake (cumulative, mass basis)

Figure 12: Dissolution Profile for the Major Components from the Dissolution of Tank 31H Saltcake with Inhibited Water 
WSRC-TR-2002-00388

Revision 0

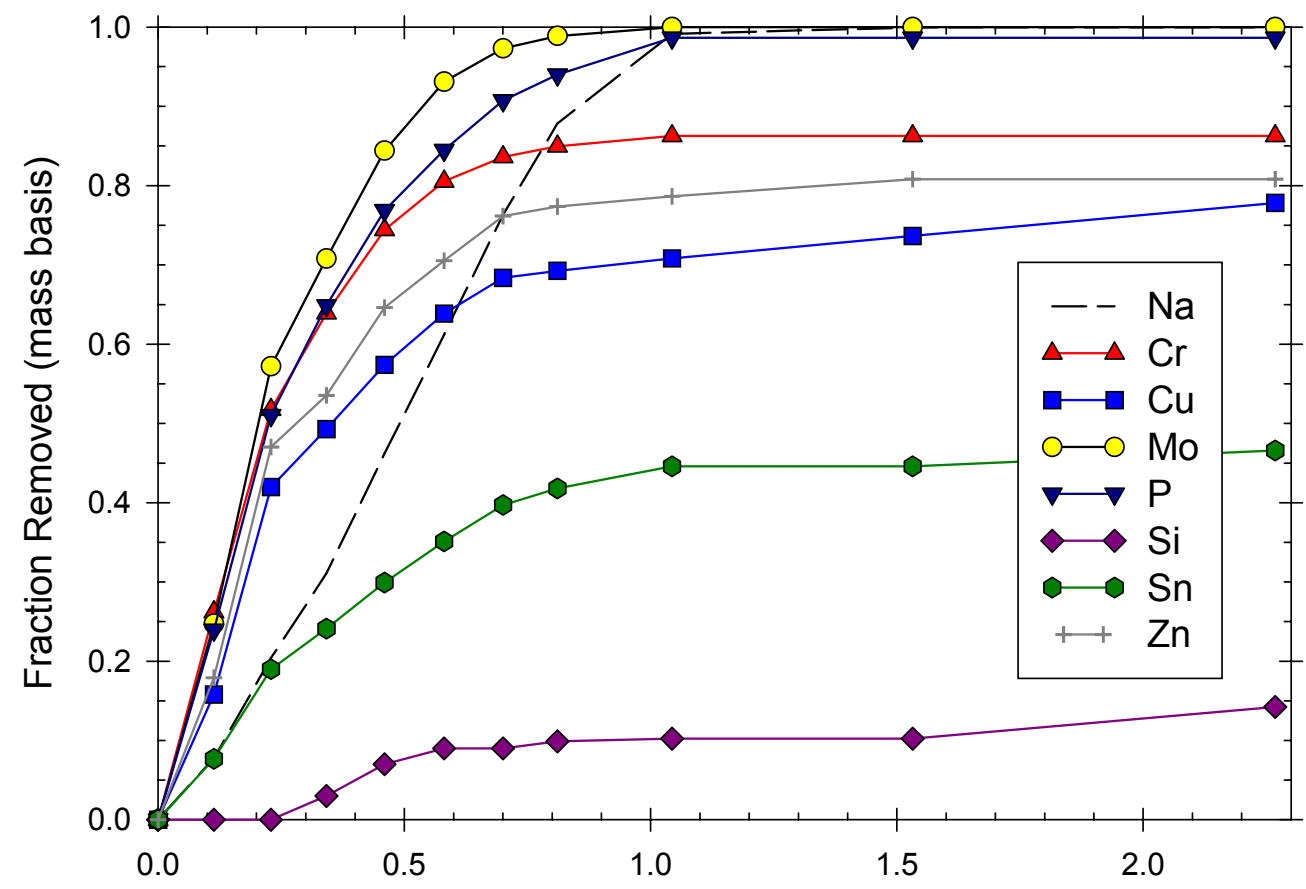

Diluent/Saltcake (cumulative, mass basis)

Figure 13: Dissolution Profile for the Minor Components from the Dissolution of Tank 31H Saltcake with Inhibited Water

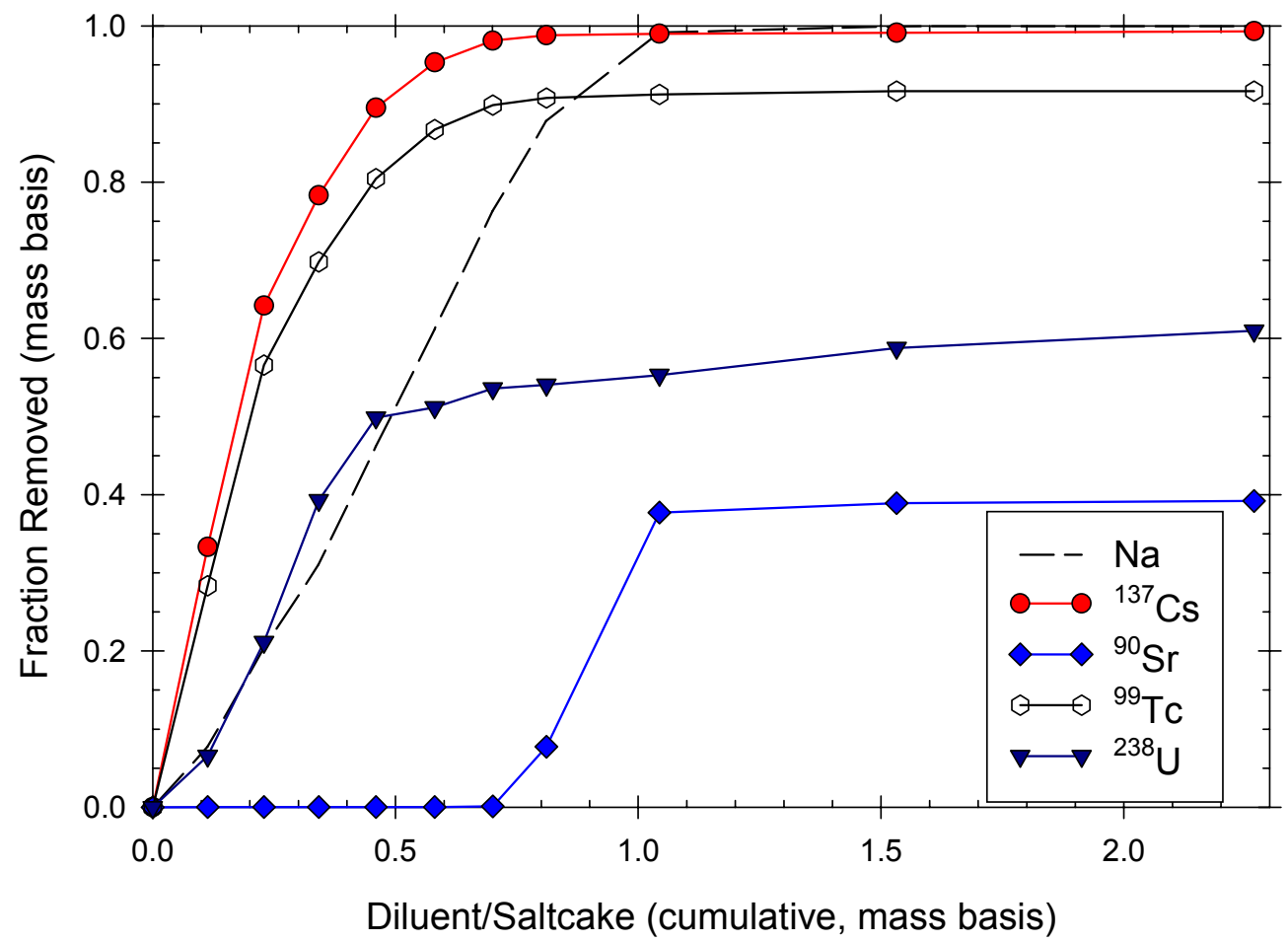

Figure 14: Dissolution Profile for Radionuclides from the Dissolution of Tank 31H Saltcake with Inhibited Water 
The dissolution profiles reveal several categories of compounds:

- A large portion of the nitrite and molybdenum are removed in the initial stages of the dissolution, with none of these compounds evident in the later dissolution stages or in the residual insoluble solids. These components are likely present entirely in the interstitial liquid of the as-received saltcake. They are fully soluble in the salt matrix at the concentrations at which they are present in the original saltcake. Hydroxide is likely also in this category of compounds, but it is not included in the dissolution profiles due to scatter in the data.

- Components such as $\mathrm{Al},{ }^{137} \mathrm{Cs},{ }^{99} \mathrm{Tc}, \mathrm{P}$, and $\mathrm{Cr}$ are also removed primarily in the initial stages rather than the later stages of dissolution. These components, however, are also found in the residual insoluble solids. A fraction of the component is resident in the interstitial liquid or as a highly soluble salt and is eluted in the initial stages. The remaining fraction of the component is not soluble at stages and is not removed. Possible explanations for this type of observation are that these components are present as more than one compound or crystal phase with differing solubilities, that these components are not soluble at the more neutral $\mathrm{pH}$ or with the potential absence of complexants in the later dissolution stages, or that these compounds adsorb onto other compounds in the insoluble solids. The inclusion of phosphate in this group of early-eluting components is unexpected because previous saltcake dissolution tests on Hanford wastes suggest that phosphate dissolves in the later dissolution stages. ${ }^{8}$ Phosphate dissolving in the early stages of Tank $31 \mathrm{H}$ dissolution is likely due to the small amount of phosphate in the original saltcake as well as the slightly elevated temperature at which the dissolution tests were performed (nominally $30^{\circ} \mathrm{C}$ ). Phosphate solubility is a strong function of temperature in salt matrixes such as this.

- The other major saltcake components (nitrate, carbonate, and sulfate) are not removed exclusively in the first stages of dissolution. They are present in the dissolved salt solutions at increasing concentrations for subsequent dissolution stages until they are no longer contained in the residual solid. This indicates that these components are present in amounts above their solubility with respect to the interstitial liquid and are primarily salt crystals in the as-received saltcake.

- The U, Zn, Cu, and Sn appear to have considerable solubility in the initial stage of salt dissolution (although they are not as soluble as the nitrite, molybdenum, cesium, aluminum, etc). A large fraction of these components, however, are not removed during the dissolution process and are evident in the residual insoluble solids.

- Strontium and silicon display virtually no solubility in the supernatant fluids of the initial salt dissolution stages. Dissolution is not noted except over a relatively small range of Diluent/Saltcake, and a significant fraction of these components are contained in the residual solids. For $\mathrm{Sr}$ and $\mathrm{Si}$, the Diluent/Salcake range over which dissolution is noted is 0.7 to 1.5 and 0.2 to 0.6 , respectively. Note that this observation for silicon may be due to the higher minimum detection limits of the initial stages, and silicon may behave more like $U, \mathrm{Zn}, \mathrm{Cu}$, and $\mathrm{Sn}$. A portion of the strontium in the saltcake is likely in the form of $\mathrm{SrCO}_{3}$, whose solubility is suppressed by the more predominant sodium carbonate phases. This test suggests that significant dissolution of the strontium salt is not evident until nearly all of the carbonate has been dissolved.

The amount of inhibited required for the dissolution of Tank $31 \mathrm{H}$ saltcake at $30{ }^{\circ} \mathrm{C}$ was shown in the previous section to be similar to that required for the dissolution of simulated SRS saltcake at $25^{\circ} \mathrm{C}$. Comparing Figure 12 and Figure 13 with the profiles obtained for the dissolution of SRS saltcake simulant, the relative dissolution of nitrate, phosphate, carbonate, and sulfate from the Tank $31 \mathrm{H}$ saltcake is somewhat different from the dissolution of the simulant at $25^{\circ} \mathrm{C}$. The relative dissolution of nitrate, phosphate, carbonate, and sulfate is, however, consistent with the simulant dissolution at $50^{\circ} \mathrm{C}^{9}$ 
Another way in which this data is presented is the chromatographic representation of Figure 15. The concentration of each component is normalized by division by the highest concentration encountered in the supernates during testing. Components with wide peaks are dissolved throughout the test while components with narrow peaks are dissolved over a limited portion of the test. The close overlay of ${ }^{137} \mathrm{Cs}$ and nitrite early in the dissolution process is also very similar to the behavior of aluminate, molybdate, chromate, phosphate, and ${ }^{99} \mathrm{Tc}$.

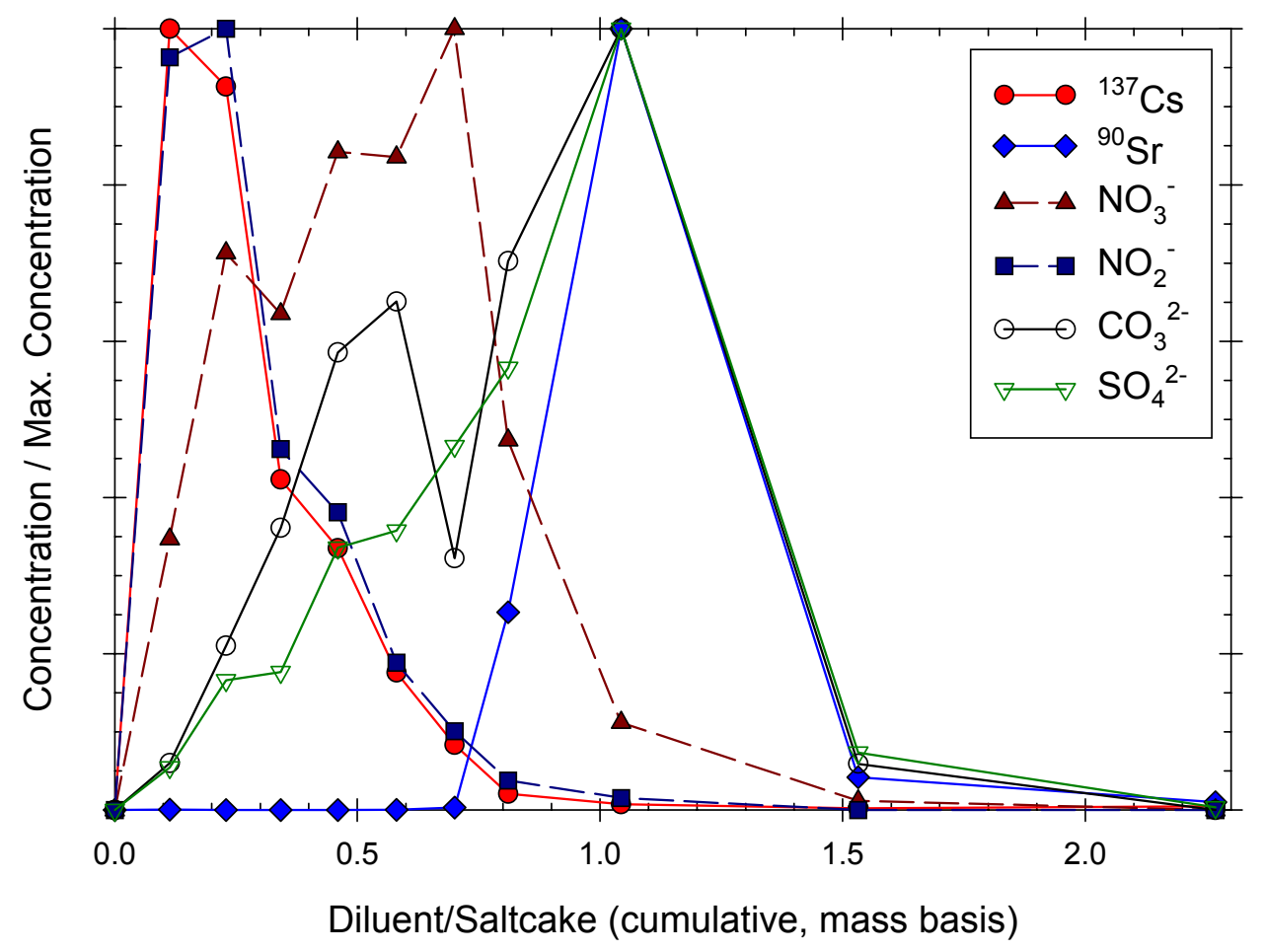

Figure 15: Chromatographic Representation of the Dissolution of Tank 31H Saltcake with Inhibited Water

The wet solids remaining after the tenth dissolution stage weighed 2.42 grams and had a volume of about $1.5 \mathrm{~mL}$, for an approximate density of $1.6 \mathrm{~g} / \mathrm{cm}^{3}$. These solids, when dried, weighed 0.83 grams, so there was approximately 1.37 grams of dried insoluble solids per 100 grams of original wet Tank $31 \mathrm{H}$ saltcake. The fraction total solids (mass of dry solids per mass of wet solids) of the solids resulting from dissolution with inhibited water is $0.343 \mathrm{~g} / \mathrm{g}$. To relate the dry insoluble solids data to the to the volume of wet solids in a tank heel, multiply the fraction total solids in the insoluble solids by the bulk density of the wet solids. For the dissolution of Tank $31 \mathrm{H}$ saltcake with IW, there was approximately 0.50 grams of dry insoluble solids per $\mathrm{cm}^{3}$ of wet insoluble solids.

Table 12 in the appendix contains the analytical results for the solids remaining after salt dissolution. These results are reported as a weight percentage of the dried residual insoluble solids. The insoluble solids contained $30.1 \mathrm{wt} \%$ aluminum, $3.6 \mathrm{wt} \% \mathrm{Fe}$, and $1.6 \mathrm{wt} \% \mathrm{Na}$. On the order of $5 \%$ to $15 \%$ of the aluminum and $60 \%$ to $70 \%$ of the iron in the as-received Tank $31 \mathrm{H}$ sample were contained in the insoluble solids resultant from dissolution with IW. XRD analysis of the solids remaining after the tenth wash revealed two crystalline phases of $\mathrm{Al}(\mathrm{OH})_{3}$ (bayerite and gibbsite) and one crystalline phase of $\mathrm{Fe}(\mathrm{OH})_{3}$ (hematite). If these are the only phases of aluminum and iron in the insoluble solids, the solids are $87.0 \mathrm{wt} \% \mathrm{Al}(\mathrm{OH})_{3}$ and $6.9 \mathrm{wt} \% \mathrm{Fe}(\mathrm{OH})_{3}$. The sulfate and sodium remaining in the insoluble solids indicates the possibility of approximately $3 \mathrm{wt} \%$ of the solids being $\mathrm{Na}_{2} \mathrm{SO}_{4}$. 


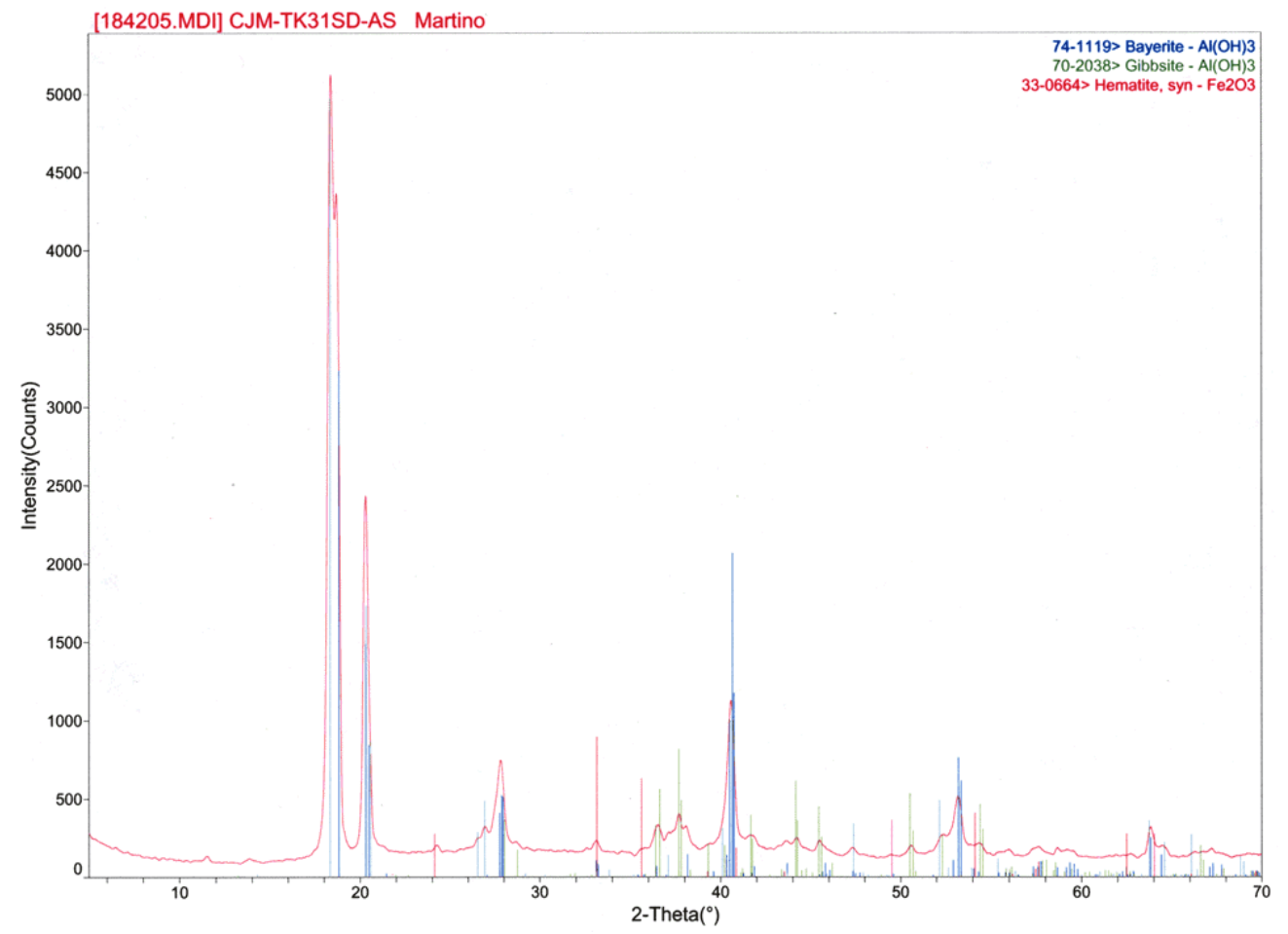

Figure 16: XRD for the Residual Insoluble Solids from the Dissolution of Tank 31H Saltcake with Inhibited Water

\section{Dissolution with HLW Supernate}

A multiple-wash dissolution test was performed by contacting 61.052 grams of Tank $31 \mathrm{H}$ saltcake with ten portions HLW Supernate from Tanks $21 \mathrm{H}, 24 \mathrm{H}$, and 26F. In total, 202 grams of this $5.2 \mathrm{M}$ $\mathrm{Na}^{+} \mathrm{HLW}$ Supernate solution was used to dissolve 84 wt \% of the saltcake. Table 9 and Table 10 contain the test data and characterization of the dissolved salt fractions adjusted for sample dilution. Figure 17 contains a plot of the decanted supernate composition versus the cumulative Diluent/Saltcake. Table 11 contains the mass of each saltcake component eluted during each washing step adjusted for the composition of the HLW Supernate dissolution fluid. Figure 18 through Figure 20 contain the dissolution profiles for the major and minor saltcake components and the key radionuclides. Except where otherwise noted, the same notes detailed for the results and discussion of the dissolution with inhibited water hold true for the dissolution with HLW Supernate.

The concentrations in Figure 17 are not adjusted to compensate for the components in the HLW Supernate dissolution fluid. From this figure, the equilibrium sodium concentration is seen to decrease steadily throughout the multiple-wash dissolution, from above $10 \mathrm{M}$ in the initial stages to below $8 \mathrm{M}$ at the final stage. The concentrations of hydroxide, nitrite, and aluminate were highest in the supernate decanted from the initial washing step and their concentrations were expected to decrease over subsequent steps asymptotically approaching the concentrations in the HLW Supernate dissolution fluid. Some measurements irregularities caused departure for this expected pattern for hydroxide. The concentrations of nitrate, carbonate, and sulfate increased through the initial several dissolution steps and decreased in the later steps as their dissolution from the saltcake became nearly complete. 
Figure 18, Figure 19, and Figure 20 are the dissolution profiles for the major salt components, the minor salt components, and select radionuclides, respectively. Sodium is contained in all dissolution profiles for reference. By the tenth washing stage, the cumulative dissolution with 3.3:1 mass of HLW Supernate to saltcake accomplished the removal of only $88 \%$ of the sodium in the original saltcake. The dissolution of a portion of this sodium would easily have been accomplished with additional HLW Supernate dissolution fluid or inhibited water.

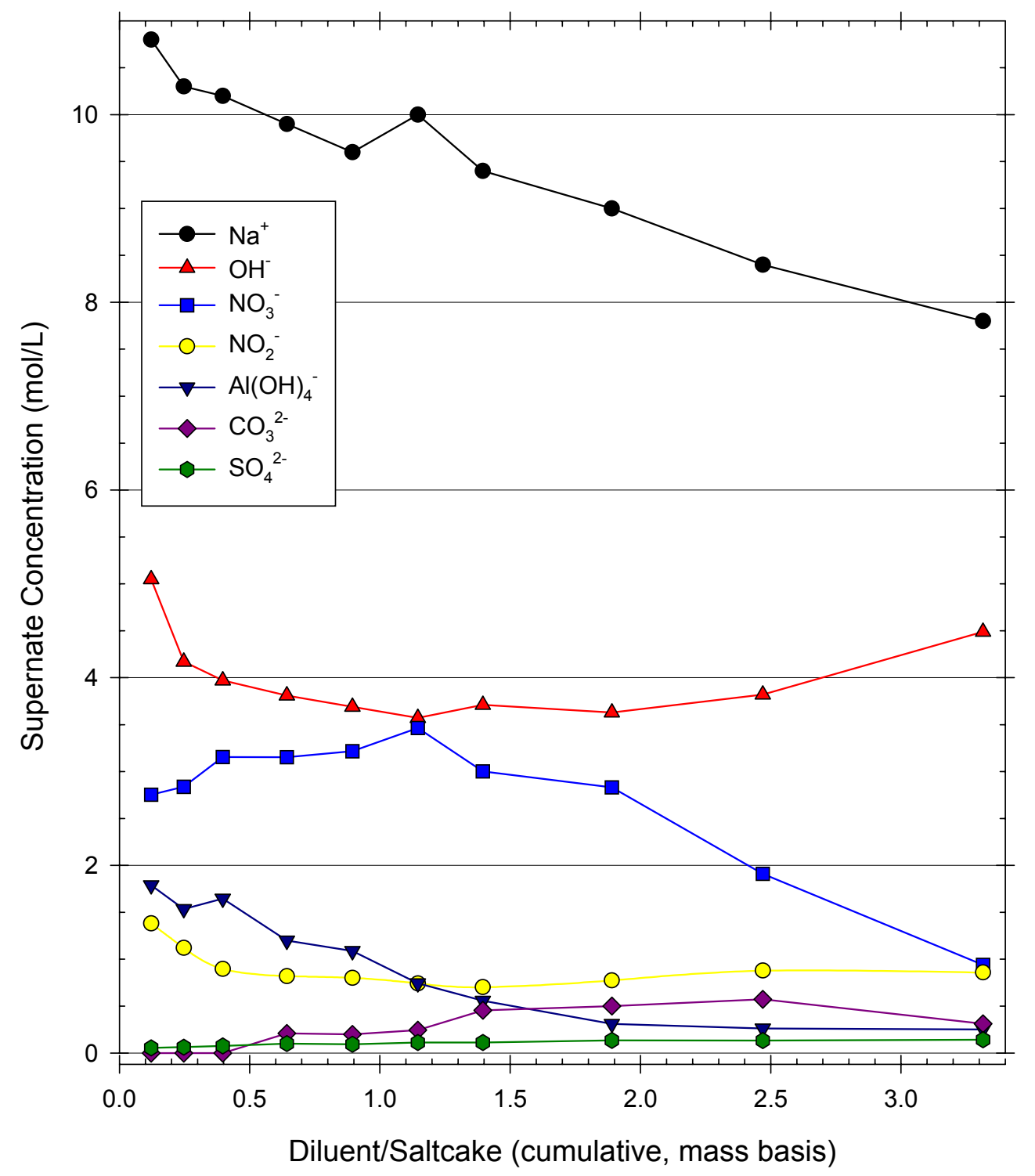

Figure 17: Supernate Composition for the Multiple-Wash Dissolution of Tank 31H Saltcake with HLW Supernate 


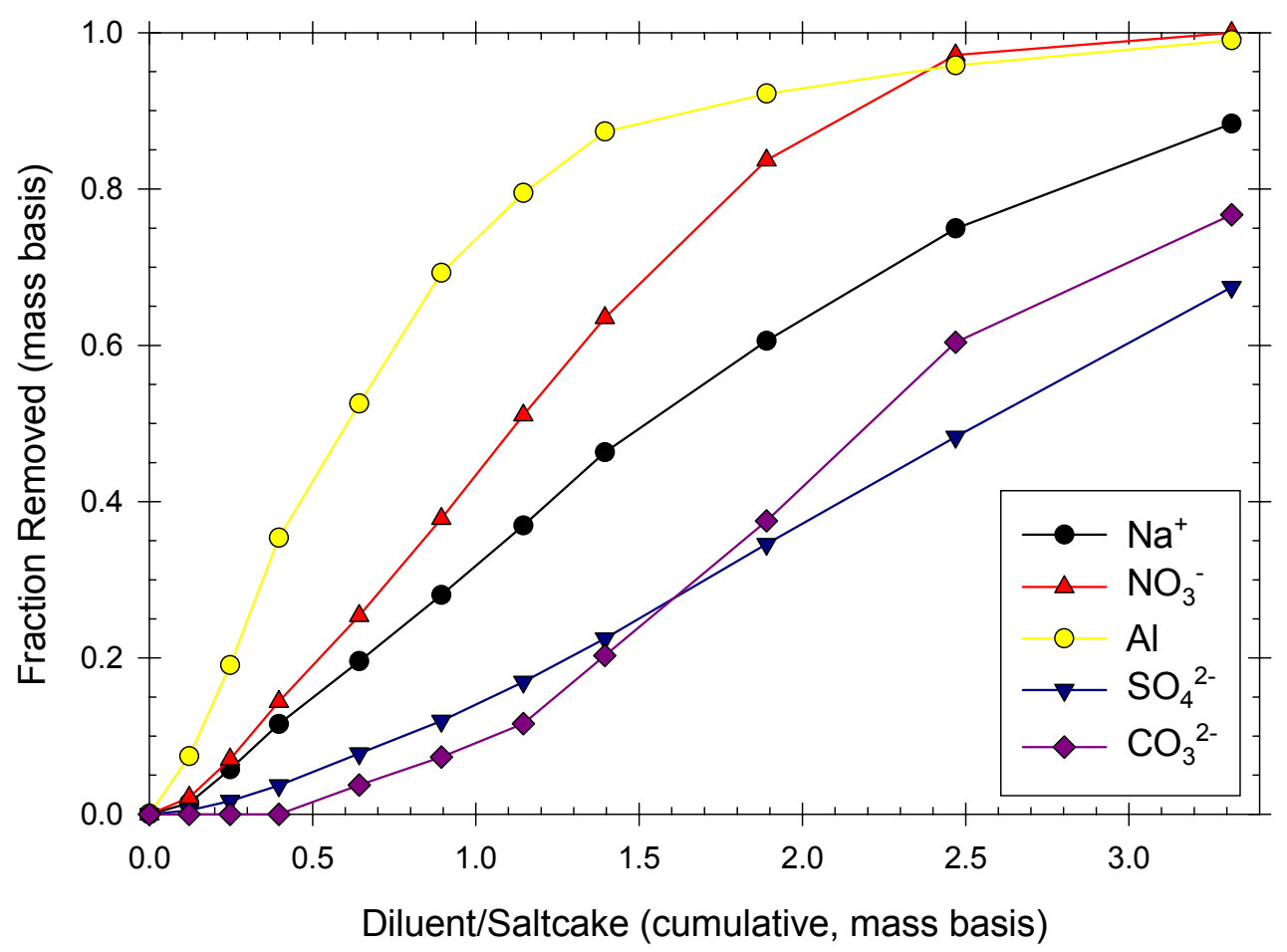

Figure 18: Dissolution Profile for the Major Components from the Dissolution of Tank 31H Saltcake with HLW Supernate

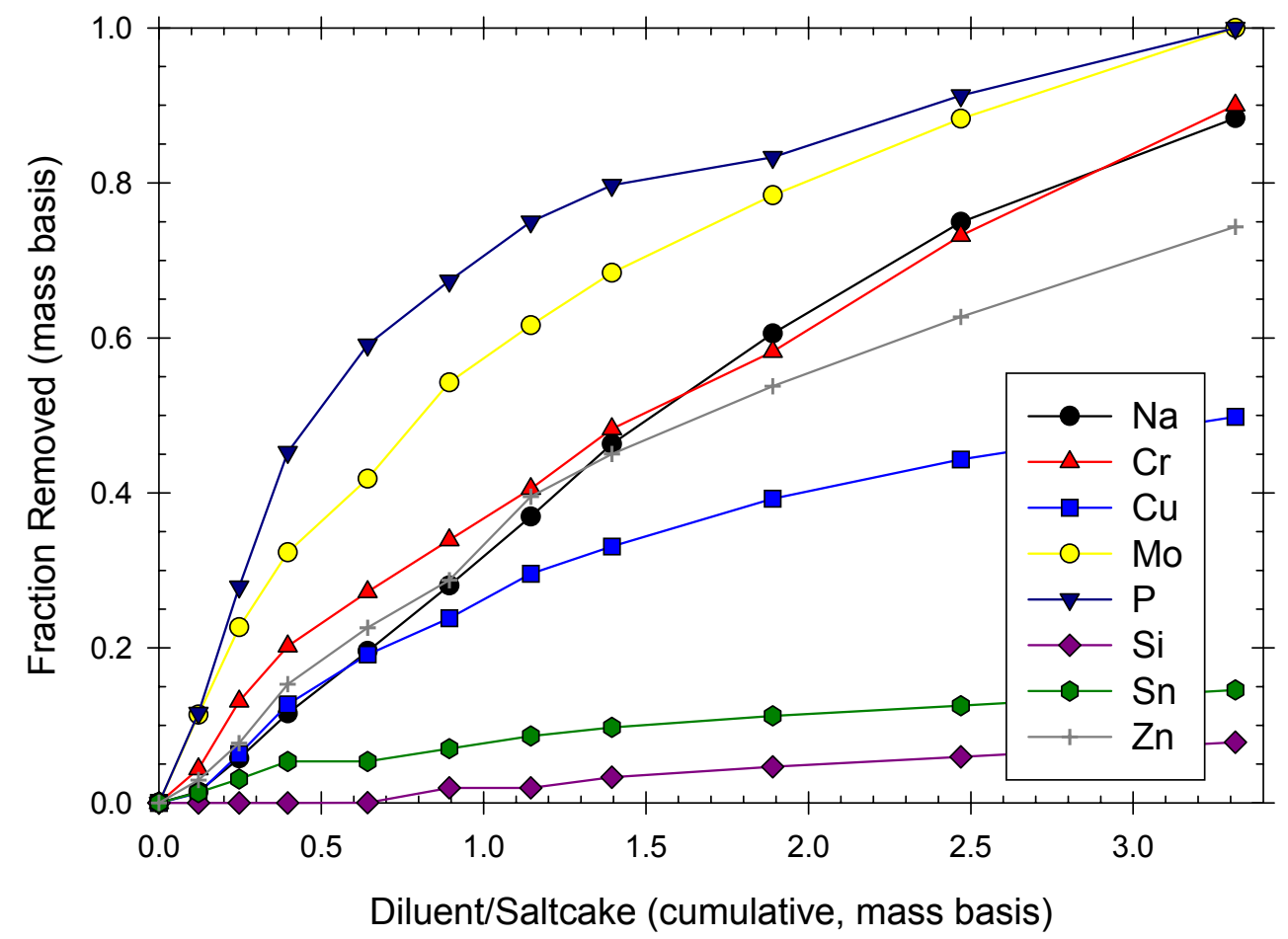

Figure 19: Dissolution Profile for the Minor Components from the Dissolution of Tank 31H Saltcake with HLW Supernate 


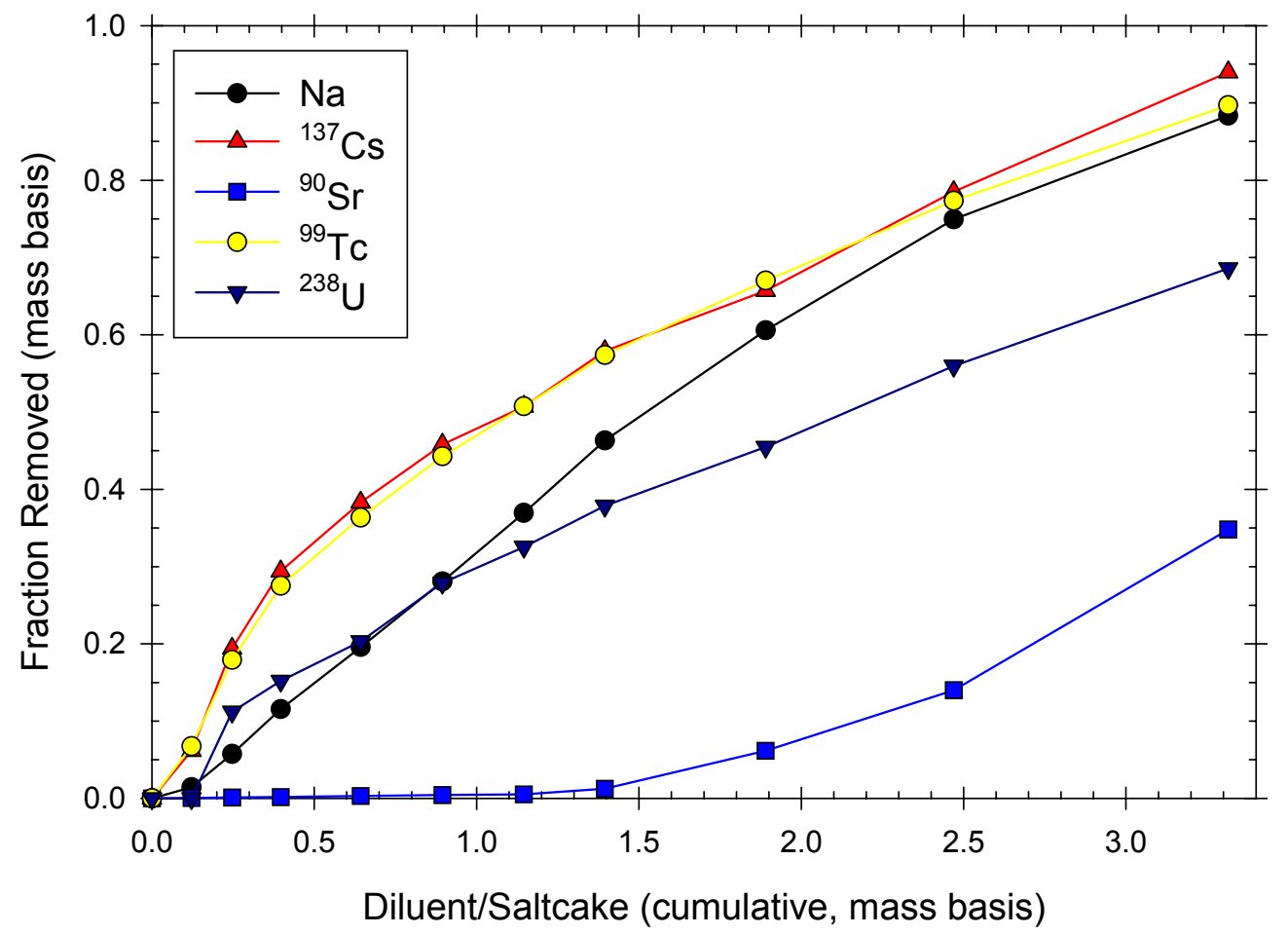

Figure 20: Dissolution Profile for Radionuclides from the Dissolution of Tank 31H Saltcake with HLW Supernate

Many of the same trends are noted for the dissolution profiles of Tank $31 \mathrm{H}$ saltcake with HLW Supernate as were noted for the dissolution with Inhibited Water. There are, however, a few clear differences observed for the dissolution with HLW Supernate:

- The dissolution with HLW Supernate required far more dissolution fluid in most cases to achieve the same degree of dissolution for each component. This is consistent with the need for a greater amount of HLW Supernate diluent for the same degree of dissolution of the bulk saltcake.

Dissolution of sodium salt components was incomplete at the conclusion of the dissolution test.

- The dissolution profiles were not as neat due to the error introduced by the significant amounts of many of the saltcake components in the HLW Supernate dissolution fluid.

- A much smaller percentage of the aluminum in the original saltcake is ultimately contained in the residual insoluble solids from dissolution with HLW supernate. About $1 \%$ of the aluminum was insoluble after the dissolution process with HLW Supernate versus $13.6 \%$ of the aluminum insoluble after dissolution with IW. This difference is likely due to the higher $\mathrm{OH}^{-}$concentration, 3.4 $\mathrm{M}$ in the HLW Supernate versus $0.01 \mathrm{M}$ in the IW, leading to more complete dissolution of the aluminum hydroxide phases. There was little evidence of gibbsite and bayerite remaining in the residual insoluble solids from the dissolution with HLW Supernate.

At the end of the dissolution test with HLW Supernate, there were salt crystals evident amongst the residual soluble solids (see the picture on the right of Figure 7). Figure 8 and Figure 9 reveal that the dissolution of Tank $31 \mathrm{H}$ saltcake with a $5.2 \mathrm{M} \mathrm{Na}^{+} \mathrm{HLW}$ Supernate was not complete after a 3.3:1 mass of diluent:saltcake had been used. Table 12 contains the analysis of the residual insoluble solids after acid dissolution. Figure 21 contains the XRD analysis of the solids at the completion of the dissolution test. The crystalline phases identified were of sodium salts of carbonate and sulfate. 


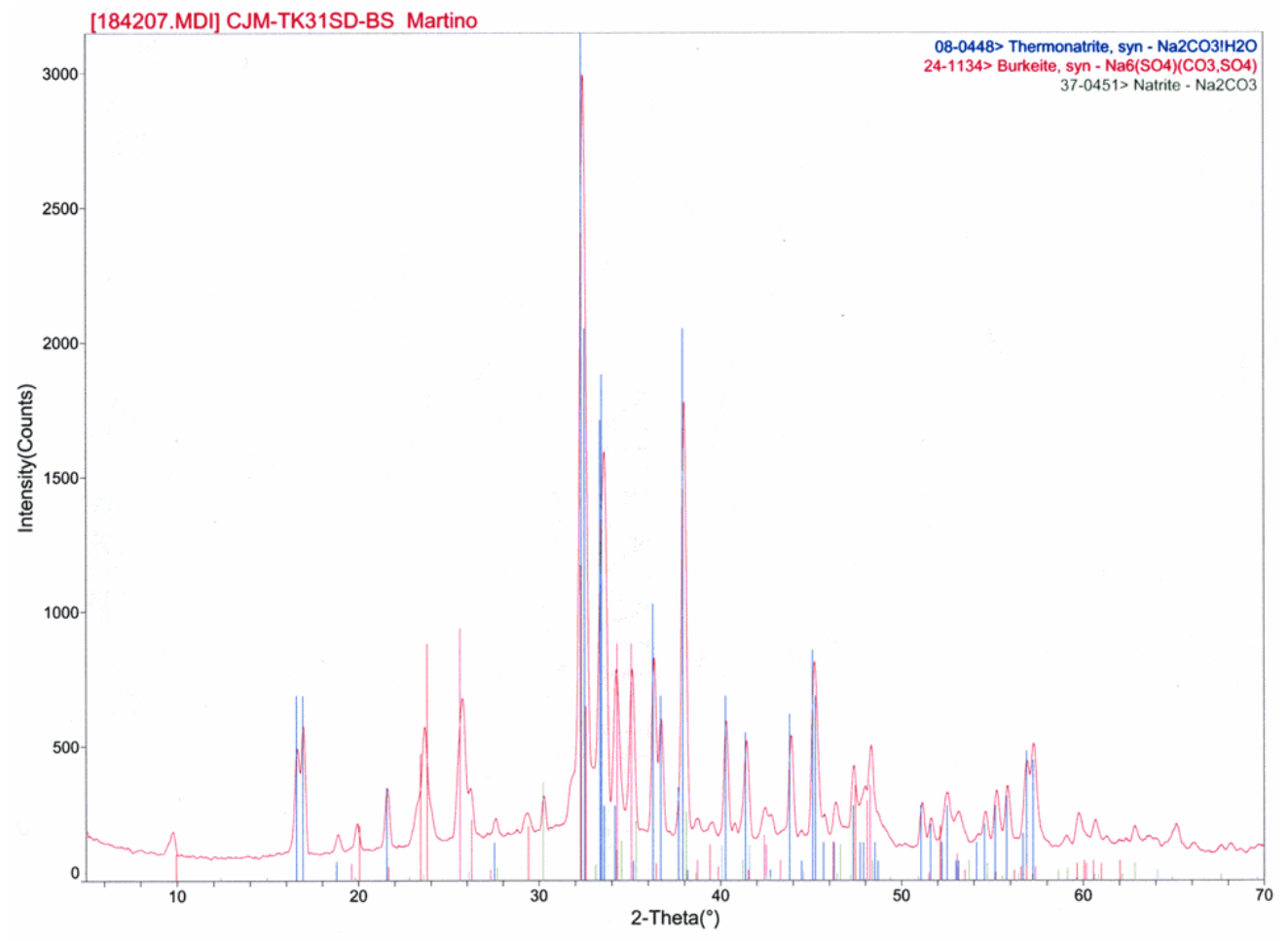

Figure 21: XRD for the Residual Insoluble Solids from the Dissolution of Tank 31H Saltcake with HLW Supernate

\section{Fissile Materials in Residual Solids}

Table 4 contains a summary of the actinides, neutron poisons, and diluents measured in the asreceived Tank $31 \mathrm{H}$ saltcake and in the insoluble solids from the dissolution tests. These results are compiled and/or calculated from Table 12 and Table 13 in the Appendix. The data for the as-received salt are on a wet basis and the data for the insoluble solids for the two dissolution fluids are on a dry basis. The "IW Soluble" analyses of the as-received saltcake are averages and standard deviations from three measurements on a 1:50 dissolution by mass with IW. The "Total" analyses of the asreceived saltcake are the results from a single acid dissolution. The analyses of the insoluble solids from the multiple-wash salt dissolution tests with IW and with HLW Supernate are reported as averages and standard deviations of two acid dissolutions of the solids from each test. The results for the dried insoluble solids contain, as a small fraction of most analytes, a contribution from the dried interstitial liquid from the final dissolution stage. Values proceeded by " $<$ " are the detection limits for analytes that were present at less than their detection limit. Values proceeded by " $\leq$ " are averages composed of both detection limits and values above the detection limits.

From the ICP-MS analysis, ${ }^{235} \mathrm{U}$ and ${ }^{238} \mathrm{U}$ were present at above detectable limits for all samples that are summarized in Table 4. The weight percentage total uranium is the sum of these uranium isotopes, plus ${ }^{233} \mathrm{U},{ }^{234} \mathrm{U}$, and ${ }^{236} \mathrm{U}$ when they are present at above detectable limits. The fractional ${ }^{235} \mathrm{U}$ enrichment is provided, calculated as the weight percentage ${ }^{235} \mathrm{U}$ divided by the total weight percentage of uranium. From the ICP-MS, ${ }^{239} \mathrm{Pu}$ was measured in the insoluble solids at above detectable concentrations. The suite of analyses that was performed did not include PUTTA analysis for ${ }^{241} \mathrm{Pu}$. The ICP-MS analysis did not provide results for Mass 241 above the detection limits for 
Table 4: Summary of Sample Results Useful to Nuclear Criticality Safety Evaluations

\begin{tabular}{|c|c|c|c|c|}
\hline & \multicolumn{2}{|c|}{ As-Received Saltcake } & \multicolumn{2}{|c|}{ Residual Insoluble Solids } \\
\hline & IW Soluble & Total & Inhibited Water Test & HLW Supern. Test \\
\hline \multicolumn{5}{|c|}{ Summary of Actinides } \\
\hline${ }^{233} \mathrm{U}(\mathrm{wt} \%)$ & $<1.04 E-5$ & $<1.06 E-4$ & $3.29 \mathrm{E}-4 \pm 4.7 \mathrm{E}-5$ & $<1.06 E-4$ \\
\hline${ }^{235} \mathrm{U}(\mathrm{wt} \%)$ & $5.63 \mathrm{E}-5 \pm 1.43 \mathrm{E}-5$ & 1.57E-4 & $3.15 \mathrm{E}-3 \pm 4.1 \mathrm{E}-4$ & $4.41 \mathrm{E}-4 \pm 1.18 \mathrm{E}-4$ \\
\hline${ }^{238} \mathrm{U}(\mathrm{wt} \%)$ & $2.45 \mathrm{E}-4 \pm 3.8 \mathrm{E}-5$ & $1.62 \mathrm{E}-3$ & $1.31 \mathrm{E}-2 \pm 6 \mathrm{E}-4$ & $3.07 \mathrm{E}-3 \pm 1.25 \mathrm{E}-3$ \\
\hline Total U (wt \%) & $3.28 \mathrm{E}-4 \pm 5.6 \mathrm{E}-5$ & $1.78 \mathrm{E}-3$ & $1.86 \mathrm{E}-2 \pm 1.1 \mathrm{E}-3$ & $3.67 \mathrm{E}-3 \pm 1.39 \mathrm{E}-3$ \\
\hline${ }^{235} \mathrm{U} /$ Tot.U & $0.170 \pm 0.015$ & 0.088 & $0.169 \pm 0.012$ & $0.123 \pm 0.014$ \\
\hline${ }^{239} \mathrm{Pu}($ wt $\%)$ & $<1.04 E-5$ & $<1.06 E-4$ & $1.00 \mathrm{E}-3 \pm 1.0 \mathrm{E}-4$ & $\leq 1.32 \mathrm{E}-04$ \\
\hline Equiv. ${ }^{235} \mathrm{U}$ (wt \%) & $5.63 \mathrm{E}-5 \pm 1.43 \mathrm{E}-5$ & 1.57E-4 & $9.03 E-3 \pm 3.3 E-4$ & $7.55 \mathrm{E}-4 \pm 5.62 \mathrm{E}-4$ \\
\hline \multicolumn{5}{|c|}{ Potential Neutron Poisons and Mass Diluents } \\
\hline $\mathrm{Na} /$ Equiv. ${ }^{235} \mathrm{U}$ & $500,000 \pm 95,000$ & 168,000 & $174 \pm 19$ & $62,300 \pm 44,200$ \\
\hline Fe/Equiv. ${ }^{235} U$ & $27.4 \pm 14.9$ & 473 & $399 \pm 57$ & $321 \pm 155$ \\
\hline Cr/Equiv. ${ }^{235} \mathrm{U}$ & $111 \pm 16$ & 46.7 & 7.10 & $18.2 \pm 8.7$ \\
\hline Mn/Equiv. ${ }^{235} \mathrm{U}$ & $<1.00$ & $<4.97$ & $6.85 \pm 0.58$ & $12.9 \pm 8.6$ \\
\hline Al/Equiv. ${ }^{235} \mathrm{U}$ & $67,900 \pm 15,300$ & 31,600 & $3,340 \pm 172$ & $584 \pm 474$ \\
\hline
\end{tabular}

these samples. A value for equivalent ${ }^{235} U$ weight percentage is calculated as the weight percentage ${ }^{235} \mathrm{U}$, plus 4 times the weight percentages of ${ }^{233} \mathrm{U}$ and ${ }^{239} \mathrm{Pu}$ (when above detection limits). Note that alternative methods for the calculation of equivalent ${ }^{235} \mathrm{U}$ exist and can be performed using the data in the Appendix. For the residual solids from dissolution with IW, the ${ }^{239} \mathrm{Pu}$ constitutes greater-than half of the equivalent ${ }^{235} \mathrm{U}$ when a multiplier of four is used in the calculation. The average of the two equivalent ${ }^{235} \mathrm{U}$ values calculated for the residual solids from dissolution with HLW Supernate has a large standard deviation associated with it. This is due to one of the two analyses for ${ }^{239} \mathrm{Pu}$ being below the detection limit as well as the variance in the uranium isotopics.

The ${ }^{235} \mathrm{U}$ enrichment in the soluble portion of the as-received saltcake and the insoluble solids from the IW dissolution test are $17.0 \%$ and $16.9 \%$, respectively. The enrichment in the insoluble solids from the HLW Supernate dissolution test is lower, at $12.3 \%$, likely due to the low uranium enrichment of the HLW Supernate solution $(0.7 \%)$. The HLW Supernate solution was not filtered before use as a dissolution fluid, and it contained some solids that likely served to lower the overall ${ }^{235} \mathrm{U}$ enrichment in the insoluble solids from salt dissolution. The enrichment of the acid-dissolution of the as-received salt is inconsistent with the water-soluble portion of the as-received salt because the ${ }^{235} \mathrm{U}$ concentration was near the detection limit for the acid-dissolution. The concentrations of uranium isotopes in the acid-dissolution of the as received sample were two to four times that of the values from the IW dissolution.

The ratios of the common neutron poisons and mass diluents to the calculated equivalent ${ }^{235} \mathrm{U}$ are provided in the lower portion of Table 4. For the as-received saltcake and the residual solid from the incomplete dissolution with HLW Supernate, sodium was present in great excess of the equivalent ${ }^{235} \mathrm{U}$. Less sodium was present in the residual solid from the dissolution with inhibited water, but the value of Na/Equiv. ${ }^{235} \mathrm{U}$ remained greater than 150 . The solids from the dissolution with IW were rich in both aluminum and iron. 


\section{Conclusions}

- The as-received Tank $31 \mathrm{H}$ saltcake was characterized to consist of primarily sodium nitrate salt with significant amounts of aluminate, carbonate, sulfate, nitrite, and hydroxide.

- The saltcake sample contained a small amount of uranium $(0.0016 \mathrm{wt} \%)$ with $\mathrm{a}^{235} \mathrm{U}$ enrichment of $17.0 \%$.

- Gamma counting revealed the activity of water-soluble ${ }^{137} \mathrm{Cs}$ to be $388 \mu \mathrm{Ci} / \mathrm{g}$, with $0.9 \%$ of the total ${ }^{137} \mathrm{Cs}$ being water-insoluble.

- Dissolution of Tank $31 \mathrm{H}$ saltcake with Inhibited Water was accomplished with an approximately $1: 1$ cumulative mass ratio of diluent to salt. At this level, $>99 \%$ of the sodium and $>95 \mathrm{wt} \%$ of the bulk salt had dissolved.

- Dissolution of Tank $31 \mathrm{H}$ saltcake with a $5.2 \mathrm{M} \mathrm{Na}^{+}$and $3.4 \mathrm{M} \mathrm{OH}^{-} \mathrm{HLW}$ Supernate solution was incomplete after a 3.3:1 cumulative mass ratio of diluent to salt. At this level, only $88 \%$ of the sodium and $84 \mathrm{wt} \%$ of the bulk salt had dissolved.

- Compositions of the different sequentially dissolved salt fractions clearly varied. Five general categories were used to describe the compounds that dissolve similarly during tests with the Tank $31 \mathrm{H}$ saltcake.

- Hydroxide, nitrite, and aluminate are removed during the earliest stages of salt dissolution. Phosphate is also eluted in early stages of dissolution relative to the sodium and nitrate. This is likely due to the small amount of phosphate in the original saltcake as well as the slightly elevated temperature at which the dissolution tests were performed.

- Of the major saltcake components, carbonate and sulfate dissolved during the latest stages.

- A portion of the ${ }^{90} \mathrm{Sr}$ was removed during the late stages of washing, likely due to $\mathrm{SrCO}_{3}$ dissolution after most $\mathrm{Na}_{2} \mathrm{CO}_{3}$ had been removed.

- The residual insoluble solid material from the dissolution of Tank $31 \mathrm{H}$ saltcake with inhibited water was $87 \mathrm{wt} \%$ gibbsite and bayerite and $7 \mathrm{wt} \%$ hematite, while the solids from the lesscomplete dissolution with HLW Supernate was primarily sodium salts of carbonate and sulfate.

\section{Recommendations}

- Consider the potential effects of the varying composition of dissolved salt when designing downstream processes.

- Data should be collected from future in-tank salt dissolution to allow for the physical aspects of salt dissolution that are not captured in this study. Modeling and pilot-scale studies may provide an intermediate bridge between laboratory- and plant-scale dissolution.

- Update the Waste Characterization System (WCS) with saltcake sample data. In comparing the compositions of as-received saltcake from Tank $31 \mathrm{H}$ with previous samples from Tanks $41 \mathrm{H}$ and $37 \mathrm{H}$, there is clear variation in the aluminum, carbonate, sulfate, and phosphate content that is not evident in WCS. 
- To gain the most information from future salt samples, analyze the samples by the multiple-wash test protocol. Without great expense (in money, time, and sample) over that of previous salt characterization efforts, the multiple-wash tests are useful in predicting the character of the dissolved salt during different stages of a saltcake recovery campaign. The protocol may be adjusted to gather information tailored to a specific situation of interest.

- Actual-waste tests involving additional alternate dissolution fluids may be warranted. Candidate fluids are those that are currently being considered for future dissolution campaigns, such as DWPF recycle (approximately $0.5 \mathrm{M} \mathrm{OH}^{-}$and $1 \mathrm{M} \mathrm{Na}^{+}$) and flush water ( $\mathrm{pH}$ of 4.5 to 5.5).

\section{Quality Assurance}

This work satisfies the requirements of the original task technical and quality assurance plan. ${ }^{10}$ Laboratory Notebooks WSRC-NB-2002-00087 and WSRC-NB-2002-00147, along with other notebooks maintained by ADS and Shield Cells personnel, contain the experimental data.

\section{Acknowledgements}

The authors would like to thank the following for their important contributions to this project:

Phyllis Burkhalter diligently performed these tests within the SRTC Shielded Cells and consistently kept the tests moving forward at a quick pace. Carolyn Conley helped to keep the Cells work moving smoothly and several of the other Shielded Cells Operations technicians contributed to the effort. Solution preparation and sample preparation was performed by Nancy Gregory. Thanks to Rob Swingle for his helpful suggestions on the logistics of performing the tests within the Shielded Cells. Also, Jeff Siler provided access to equipment and lent technical support in order to get good pictures of the samples and experiments within the Shielded Cells.

Jeff Pike of HLW process engineering provided his ideas during the planning stages of these tests. He was persistent in pushing for the delivery of an actual-waste sample. Bob Hinds of HLW was instrumental in obtaining the actual-waste Tank $31 \mathrm{H}$ saltcake sample for the purpose of these tests. Phil McGinnis of Oak Ridge National Lab provided programmatic oversight for the Tanks Focus Area and facilitated communication with others within the DOE complex. As with the simulant saltcake dissolution tests, Dan Herting of Fluor Hanford provided technical assistance and shared his experiences with similar dissolution tests on Hanford Site actual-waste saltcake.

Jon Kuhns and Daro Ferrara coordinated the efforts of ADS. We would like to thank the researchers and analysts within ADS for their assistance, including Chuck Coleman, David Diprete, Amy Ekechukwu, Robert Ray, June Hart, Mira Malek, Art Jurgensen, David Missimer, and Beverly Burch. Also, we thank the numerous ADS technicians who contributed to this work.

\section{References}

${ }^{1}$ D. T. Hobbs, "Final Report: Analysis of Tank 41H Saltcake Sample \#2 and Comparison to Sample \#1," WSRC-TR-94-057, January 26, 1994.

${ }^{2}$ D. T. Hobbs, "Final Report on the Analytical Results for Tank Farm Samples in Support of Salt Dissolution Evaluations," WSRC-TR-96-0410, Revision 0, December 12, 1996. 
${ }^{3}$ C. J.Martino, "Tank 41H Salt-Well Sample Analysis," WSRC-TR-2002-00343, Revision 0, August 15, 2002.

${ }^{4}$ B. J. Wiersma, "Recommendations for the Use of Inhibited Water During Phase I Salt Dissolution in Tank 41," WSRC-TR-96-0085, January, 1996.

${ }^{5}$ B. J. Wiersma, "An Investigation of Density Driven Salt Dissolution Techniques," WSRC-TR-960160, August 1996.

${ }^{6}$ D. L. Herting, D. W. Edmonson, J. R. Smith, T. A. Hill, and C. H. Delegard, "Saltcake Dissolution FY 1999 Status Report," HNF-5193, Rev. 0, September 1999.

${ }^{7}$ D. L. Herting, "Saltcake Dissolution FY 2000 Status Report," HNF-7031, Rev. 0, September 2000.

${ }^{8}$ D. L. Herting, "Saltcake Dissolution FY 2001 Status Report," HNF-8849, Rev. 0, September 2001.

${ }^{9}$ C. J. Martino, M. R. Poirier, and N. E. Gregory, "Saltcake Dissolution Simulant Tests," WSRC-TR2002-00387, Revision 0, December 11, 2002.

${ }^{10}$ C. J. Martino, "Task Technical and Quality Assurance Plan for FY02 Salt Dissolution Actual-Waste Studies," WSRC-RP-2002-00378, Revision 0, July 29, 2002.

${ }^{11}$ L. N. Oji, "Characterization of Tank 37H Salt Core Samples," WSRC-TR-2001-00517, Revision 0, November 12, 2001.

${ }^{12}$ W. R. Wilmarth, "Tank 21H Sample Analysis," SRT-LWP-2002-00029, February 22, 2002.

${ }^{13}$ W. R. Wilmarth, "Tank 26F Sample Analysis," SRT-LWP-2002-00033, March 25, 2002.

${ }^{14}$ W. R. Wilmarth, "Tank 34F and 24H Sample Analysis," SRT-LWP-2002-00098, September 13, 2002. 
WSRC-TR-2002-00388

Revision 0

\section{Appendix}

Page 28 of 47 
WSRC-TR-2002-00388

Revision 0

Table 5: Analysis of ${ }^{125} \mathrm{Sb}$ and ${ }^{126} \mathrm{Sn}$ in Samples from the Dissolution of Tank 31H Saltcake with Inhibited Water

\begin{tabular}{|l|c|c|}
\hline & $\begin{array}{c}{ }^{125} \mathrm{Sb} \\
\mathrm{nCi} / \mathrm{mL}\end{array}$ & $\begin{array}{c}{ }^{126} \mathrm{Sn} \\
\mathrm{nCi} / \mathrm{mL}\end{array}$ \\
\hline $1^{\text {st }}$ wash & 1.22 & 2.14 \\
\hline $2^{\text {nd }}$ wash & 1.33 & 1.29 \\
\hline $5^{\text {th }}$ wash & 0.466 & 0.212 \\
\hline
\end{tabular}

\section{$\underline{\text { Notes for Table } 5}$}

Additional analyses were completed on ${ }^{125} \mathrm{Sb}$ and ${ }^{126} \mathrm{Sn}$ by cesium removal and gamma radiation counting. To convert to a mass basis, use the supernate densities contained in Table 6. 
WSRC-TR-2002-00388

Revision 0

Table 6: Test Data and ICP-ES Results for Tank 31H Salt Dissolution with Inhibited Water

\begin{tabular}{|c|c|c|c|c|c|c|}
\hline Wash \# & 1 & 2 & 3 & 4 & 5 & 6 \\
\hline $\begin{array}{l}\text { Diluent/Saltcake } \\
\text { (cumulative mass basis) }\end{array}$ & 0.113 & 0.229 & 0.342 & 0.460 & 0.581 & 0.700 \\
\hline Supernate Removed (g) & 8.8 & 14.7 & 12.6 & 16.1 & 17.3 & 18.1 \\
\hline Supernate (vol. \%) & 18.9 & 23.6 & 28.4 & 38.7 & 47.3 & 61.9 \\
\hline Undissolved Salt (wt \%) & 96.9 & 84.3 & 74.9 & 60.2 & 43.8 & 25.9 \\
\hline Supernate Density $\left(\mathrm{g} / \mathrm{cm}^{3}\right)$ & 1.474 & 1.463 & 1.446 & 1.439 & 1.451 & 1.440 \\
\hline Est. Solid Density $\left(\mathrm{g} / \mathrm{cm}^{3}\right)$ & 1.96 & 1.86 & 1.90 & 1.92 & 1.83 & 1.96 \\
\hline Charge Balance $(-/+)(\%)$ & 107 & 106 & 105 & 106 & 90 & 90 \\
\hline \multicolumn{7}{|c|}{$I C P$-ES (mol/L) } \\
\hline $\mathrm{Ag}$ & $<1.28 E-04$ & $<1.29 E-04$ & $<4.10 E-05$ & $<3.31 E-05$ & $<2.46 E-05$ & $<1.84 E-05$ \\
\hline $\mathrm{Al}$ & $2.28 \mathrm{E}+00$ & $1.91 \mathrm{E}+00$ & 1.17E+00 & 7.52E-01 & 4.23E-01 & $1.51 \mathrm{E}-01$ \\
\hline B & $6.39 \mathrm{E}-03$ & $<4.49 E-03$ & 2.06E-03 & $<1.16 E-03$ & $<8.59 E-04$ & $<6.41 E-04$ \\
\hline $\mathrm{Ba}$ & $<2.40 E-04$ & $<2.40 E-04$ & $<7.66 E-05$ & $<6.17 E-05$ & $<4.59 E-05$ & $<3.42 E-05$ \\
\hline $\mathrm{Ca}$ & $<9.93 E-04$ & $<9.94 E-04$ & $<3.18 E-04$ & $<2.56 E-04$ & $<1.90 E-04$ & $<1.42 E-04$ \\
\hline $\mathrm{Cd}$ & $<6.47 E-05$ & $<6.48 E-05$ & $<2.07 E-05$ & $<1.67 E-05$ & $<1.24 E-05$ & $<9.25 E-06$ \\
\hline $\mathrm{Ce}$ & $<3.34 E-04$ & $<3.34 E-04$ & $<1.07 E-04$ & $<8.59 E-05$ & $<6.39 E-05$ & $<4.77 E-05$ \\
\hline $\mathrm{Cr}$ & 3.27E-03 & 1.86E-03 & 1.04E-03 & 6.08E-04 & 3.78E-04 & 1.81E-04 \\
\hline $\mathrm{Cu}$ & 3.51E-04 & 3.38E-04 & 1.11E-04 & 8.49E-05 & 7.15E-05 & 4.75E-05 \\
\hline $\mathrm{Fe}$ & $1.15 \mathrm{E}-04$ & $<1.12 E-04$ & $<3.57 E-05$ & $<2.87 E-05$ & $<2.14 E-05$ & $<1.60 E-05$ \\
\hline $\mathrm{Gd}$ & $<2.58 E-04$ & $<2.58 E-04$ & $<8.24 E-05$ & $<6.64 E-05$ & $<4.94 E-05$ & $<3.68 E-05$ \\
\hline $\mathrm{K}$ & $<4.15 E-02$ & $<4.16 E-02$ & $<1.33 E-02$ & $<1.07 E-02$ & $<7.96 E-03$ & $<5.94 E-03$ \\
\hline La & $<8.97 E-05$ & $<8.98 E-05$ & $<2.87 E-05$ & $<2.31 E-05$ & $<1.84 E-05$ & $<1.28 E-05$ \\
\hline $\mathrm{Li}$ & $<1.07 E-02$ & $<1.07 E-02$ & $<3.43 E-03$ & $<2.76 E-03$ & $<2.06 E-03$ & $<1.53 E-03$ \\
\hline $\mathrm{Mg}$ & $<3.78 E-04$ & $<3.78 E-04$ & $<1.21 E-04$ & $<9.72 E-05$ & $<7.23 E-05$ & $<5.40 E-05$ \\
\hline $\mathrm{Mn}$ & $<2.52 E-05$ & $<2.52 E-05$ & $<8.06 E-06$ & $<6.49 E-06$ & $<4.83 E-06$ & $<3.60 E-06$ \\
\hline Mo & $1.82 \mathrm{E}-03$ & 1.37E-03 & 6.86E-04 & 4.69E-04 & 3.20E-04 & 1.47E-04 \\
\hline $\mathrm{Na}$ & $9.61 \mathrm{E}+00$ & $9.17 \mathrm{E}+00$ & $9.08 \mathrm{E}+00$ & $8.87 \mathrm{E}+00$ & $9.30 \mathrm{E}+00$ & $8.84 \mathrm{E}+00$ \\
\hline $\mathrm{Ni}$ & $<3.98 E-04$ & $<3.99 E-04$ & $<1.27 E-04$ & $<1.03 E-04$ & $<7.63 E-05$ & $<5.69 E-05$ \\
\hline$P$ & 1.15E-02 & 8.11E-03 & 4.56E-03 & 3.07E-03 & $1.82 \mathrm{E}-03$ & $1.41 \mathrm{E}-03$ \\
\hline $\mathrm{Pb}$ & $<2.67 E-04$ & $<2.67 E-04$ & $<8.52 E-05$ & $<6.87 E-05$ & $<5.11 E-05$ & $<3.81 E-05$ \\
\hline$S$ & 8.32E-02 & $1.45 \mathrm{E}-01$ & $1.85 \mathrm{E}-01$ & 2.73E-01 & 2.72E-01 & 3.36E-01 \\
\hline $\mathrm{Sb}$ & $<5.37 E-03$ & $<5.38 E-03$ & $<1.72 E-03$ & $<1.38 E-03$ & $<1.03 E-03$ & $<7.68 E-04$ \\
\hline $\mathrm{Si}$ & $<1.03 E-03$ & $<1.03 E-03$ & 1.16E-03 & 8.21E-04 & $5.08 \mathrm{E}-04$ & $<1.47 E-04$ \\
\hline Sn & 1.05E-03 & 8.70E-04 & 4.76E-04 & $4.21 \mathrm{E}-04$ & $3.52 \mathrm{E}-04$ & $2.98 \mathrm{E}-04$ \\
\hline $\mathrm{Sr}$ & $<1.50 E-04$ & $<1.50 E-04$ & $<4.80 E-05$ & $<3.87 E-05$ & $<2.88 E-05$ & $<2.15 E-05$ \\
\hline $\mathrm{Ti}$ & $<2.78 E-04$ & $<2.79 E-04$ & $<8.90 E-05$ & $<7.17 E-05$ & $<5.33 E-05$ & $<3.98 E-05$ \\
\hline$U$ & $<1.65 E-03$ & $<1.65 E-03$ & $<5.28 E-04$ & $<4.25 E-04$ & $<3.16 E-04$ & $<2.36 E-04$ \\
\hline $\mathrm{Zn}$ & 2.01E-04 & 1.67E-04 & 4.99E-05 & 6.89E-05 & 3.30E-05 & 2.99E-05 \\
\hline $\mathrm{Zr}$ & $<4.33 E-04$ & $<4.33 E-04$ & $<1.38 E-04$ & $<1.11 E-04$ & $<8.29 E-05$ & $<6.19 E-05$ \\
\hline
\end{tabular}


Table 6 Continued

\begin{tabular}{|c|c|c|c|c|c|}
\hline Wash \# & 7 & 8 & 9 & 10 & 2 \\
\hline $\begin{array}{l}\text { Diluent/Saltcake } \\
\text { (cumulative mass basis) }\end{array}$ & 0.811 & 1.043 & 1.532 & 2.268 & \multirow{7}{*}{ Duplicate } \\
\hline Supernate Removed (g) & 13.5 & 20.4 & 30.1 & 44.6 & \\
\hline Supernate (vol. \%) & 66.7 & 88.9 & 95.3 & 96.8 & \\
\hline Undissolved Salt (wt \%) & 14.7 & 4.4 & 3.8 & 4.0 & \\
\hline Supernate Density $\left(\mathrm{g} / \mathrm{cm}^{3}\right)$ & 1.437 & 1.250 & 1.022 & 1.002 & \\
\hline Est. Solid Density $\left(\mathrm{g} / \mathrm{cm}^{3}\right)$ & 1.79 & 1.34 & 1.52 & 1.61 & \\
\hline Charge Balance (\%) & 88 & 87 & 75 & 125 & \\
\hline \multicolumn{6}{|c|}{ ICP-ES (mol/L) } \\
\hline $\mathrm{Ag}$ & $<4.16 E-06$ & $<4.05 E-06$ & $<4.38 E-06$ & $<3.94 E-06$ & $<1.29 E-04<3.31 E-05$ \\
\hline $\mathrm{Al}$ & 3.74E-02 & $5.53 \mathrm{E}-03$ & $1.21 \mathrm{E}-03$ & 8.45E-04 & $1.90 \mathrm{E}+00 \quad 7.52 \mathrm{E}-01$ \\
\hline $\mathrm{B}$ & $<1.45 E-04$ & $<1.42 E-04$ & $<1.53 E-04$ & $<1.38 E-04$ & $<4.49 \mathrm{E}-03 \quad 1.18 \mathrm{E}-03$ \\
\hline $\mathrm{Ba}$ & 2.23E-05 & $1.60 \mathrm{E}-05$ & $<8.17 E-06$ & $<7.35 E-06$ & $<2.40 E-04<6.17 E-05$ \\
\hline $\mathrm{Ca}$ & $<3.22 E-05$ & $6.63 \mathrm{E}-05$ & $<3.39 E-05$ & $<3.05 E-05$ & $<9.94 E-04<2.56 E-04$ \\
\hline $\mathrm{Cd}$ & $<2.09 E-06$ & $<2.04 E-06$ & $<2.21 E-06$ & $<1.99 E-06$ & $<6.48 E-05<1.67 E-05$ \\
\hline $\mathrm{Ce}$ & 2.60E-05 & $1.62 \mathrm{E}-05$ & $<1.14 E-05$ & $<1.02 E-05$ & $<3.34 E-04<8.59 E-05$ \\
\hline $\mathrm{Cr}$ & 1.07E-04 & 5.90E-05 & $<6.81 E-06$ & $<6.13 E-06$ & 1.90E-03 6.33E-04 \\
\hline $\mathrm{Cu}$ & $1.24 \mathrm{E}-05$ & 1.27E-05 & 1.27E-05 & 1.24E-05 & 3.49E-04 8.56E-05 \\
\hline $\mathrm{Fe}$ & $5.22 \mathrm{E}-06$ & $<3.52 E-06$ & $<3.80 E-06$ & $<3.43 E-06$ & $<1.12 E-04<2.87 E-05$ \\
\hline $\mathrm{Gd}$ & $<8.34 E-06$ & $<8.13 E-06$ & $<8.78 E-06$ & $<7.91 E-06$ & $<2.58 E-04<6.64 E-05$ \\
\hline $\mathrm{K}$ & $<1.34 E-03$ & $<1.31 E-03$ & $<1.42 E-03$ & $<1.28 E-03$ & $<4.16 E-02<1.07 E-02$ \\
\hline $\mathrm{La}$ & $6.34 \mathrm{E}-06$ & 4.72E-06 & $<3.06 E-06$ & $<2.76 E-06$ & $<8.98 E-05<2.31 E-05$ \\
\hline $\mathrm{Li}$ & $<3.47 E-04$ & $<3.39 E-04$ & $<3.66 E-04$ & $<3.29 E-04$ & $<1.07 E-02<2.76 E-03$ \\
\hline $\mathrm{Mg}$ & $<1.22 E-05$ & $<1.19 E-05$ & $<1.29 E-05$ & $<1.16 E-05$ & $<3.78 E-04<9.72 E-05$ \\
\hline $\mathrm{Mn}$ & $<8.16 E-07$ & $<7.96 E-07$ & $<8.59 E-07$ & $<7.74 E-07$ & $<2.52 E-05<6.49 E-06$ \\
\hline Mo & 7.13E-05 & 3.02E-05 & $<3.26 E-05$ & $<2.94 E-05$ & $1.45 \mathrm{E}-03 \quad 4.74 \mathrm{E}-04$ \\
\hline $\mathrm{Na}$ & $9.07 E+00$ & $5.14 \mathrm{E}+00$ & 2.17E-01 & 2.49E-02 & $9.40 \mathrm{E}+00 \quad 8.93 \mathrm{E}+00$ \\
\hline $\mathrm{Ni}$ & 1.94E-05 & $1.53 \mathrm{E}-05$ & $<1.36 E-05$ & $<1.22 E-05$ & $<3.99 E-04<1.03 E-04$ \\
\hline$P$ & 9.97E-04 & 8.13E-04 & $<1.31 E-04$ & $<1.18 E-04$ & 7.27E-03 2.46E-03 \\
\hline $\mathrm{Pb}$ & $<8.63 E-06$ & $1.18 \mathrm{E}-05$ & $<9.09 E-06$ & $<8.18 E-06$ & $<2.67 E-04<6.87 E-05$ \\
\hline$S$ & 5.47E-01 & 5.57E-01 & 2.26E-02 & $6.52 \mathrm{E}-04$ & 1.55E-01 2.73E-01 \\
\hline $\mathrm{Sb}$ & $<1.74 E-04$ & $<1.70 E-04$ & $<1.83 E-04$ & $<1.65 E-04$ & $<5.38 E-03<1.38 E-03$ \\
\hline $\mathrm{Si}$ & 1.67E-04 & 6.17E-05 & $<3.51 E-05$ & $2.59 \mathrm{E}-04$ & $<1.03 E-03 \quad 8.99 \mathrm{E}-04$ \\
\hline Sn & $1.78 \mathrm{E}-04$ & $1.40 \mathrm{E}-04$ & $<2.24 E-05$ & $3.55 \mathrm{E}-05$ & 9.61E-04 3.37E-04 \\
\hline $\mathrm{Sr}$ & $<4.86 E-06$ & $1.52 \mathrm{E}-05$ & $<5.12 E-06$ & $<4.61 E-06$ & $<1.50 E-04<3.87 E-05$ \\
\hline $\mathrm{Ti}$ & $<9.01 E-06$ & $<8.79 E-06$ & $<9.49 E-06$ & $<8.55 E-06$ & $<2.79 E-04<7.17 E-05$ \\
\hline$U$ & $<5.35 E-05$ & $<5.21 E-05$ & $<5.63 E-05$ & $<5.07 E-05$ & $<1.65 E-03<4.25 E-04$ \\
\hline $\mathrm{Zn}$ & $8.40 \mathrm{E}-06$ & 5.35E-06 & 4.87E-06 & $<2.60 E-06$ & $2.20 \mathrm{E}-04 \quad 5.12 \mathrm{E}-05$ \\
\hline $\mathrm{Zr}$ & $<1.40 E-05$ & $<1.37 E-05$ & $<1.48 E-05$ & $<1.33 E-05$ & $<4.33 E-04<1.11 E-04$ \\
\hline
\end{tabular}


WSRC-TR-2002-00388

Revision 0

Table 7: Results from IC Anions, Wet Chemistry, Rad. Chem., and ICP-MS for Tank 31H Salt Dissolution with Inhibited Water

\begin{tabular}{|c|c|c|c|c|c|c|}
\hline Wash \# & 1 & 2 & 3 & 4 & 5 & 6 \\
\hline \multicolumn{7}{|c|}{ IC Anions (mol/L) } \\
\hline $\mathrm{NO}_{3}^{-}$ & $3.41 \mathrm{E}+00$ & $4.14 \mathrm{E}+00$ & $4.27 E+00$ & $4.08 \mathrm{E}+00$ & $4.08 \mathrm{E}+00$ & $4.63 E+00$ \\
\hline $\mathrm{NO}_{2}^{-}$ & $9.22 \mathrm{E}-01$ & $5.65 \mathrm{E}-01$ & 3.07E-01 & $1.85 \mathrm{E}-01$ & 9.52E-02 & $5.11 \mathrm{E}-02$ \\
\hline $\mathrm{SO}_{4}{ }^{2-}$ & 5.77E-02 & $1.23 \mathrm{E}-01$ & $1.57 \mathrm{E}-01$ & $2.40 \mathrm{E}-01$ & 2.36E-01 & 3.09E-01 \\
\hline $\mathrm{PO}_{4}^{3-}$ & $<1.82 E-01$ & $<1.82 E-01$ & 5.83E-02 & $<4.70 E-02$ & $<3.49 E-02$ & $<2.61 E-02$ \\
\hline $\mathrm{Cl}^{-}$ & $<9.77 E-02$ & $<9.78 E-02$ & $=3.12 E-02$ & $<2.52 E-02$ & $<1.87 E-02$ & $<1.40 E-02$ \\
\hline $\mathrm{F}^{-}$ & $<1.82 E-01$ & $<1.82 E-01$ & $=5.83 E-02$ & $<4.69 E-02$ & $<3.49 E-02$ & $<2.61 E-02$ \\
\hline $\mathrm{C}_{2} \mathrm{O}_{4}{ }^{2-}$ & $<1.97 E-01$ & $<1.97 E-01$ & $6.29 E-02$ & $<5.07 E-02$ & $<3.77 E-02$ & $<2.81 E-02$ \\
\hline $\mathrm{CHO}_{2}^{-}$ & $<3.85 E-01$ & $<3.85 E-01$ & = $1.23 E-01$ & $<9.91 E-02$ & $<7.37 E-02$ & $<5.50 E-02$ \\
\hline \multicolumn{7}{|c|}{ Wet Chemistry (mol/L) } \\
\hline Total Base & $5.55 \mathrm{E}+00$ & $4.17 \mathrm{E}+00$ & $3.66 \mathrm{E}+00$ & $3.40 \mathrm{E}+00$ & $2.50 \mathrm{E}+00$ & $2.09 E+00$ \\
\hline $\mathrm{CO}_{3}{ }^{2-}$ & 2.15E-01 & 5.11E-01 & 8.86E-01 & 1.16E+00 & 1.16E+00 & 5.45E-01 \\
\hline Free $\mathrm{OH}$ (measured) & 5.31E-01 & $-5.08 E-01$ & $1.78 \mathrm{E}-01$ & $1.22 \mathrm{E}-02$ & $-2.31 \mathrm{E}-01$ & $-1.77 \mathrm{E}-01$ \\
\hline Free $\mathrm{OH}$ (calculated) & $3.05 E+00$ & $1.75 \mathrm{E}+00$ & $1.61 \mathrm{E}+00$ & $1.49 \mathrm{E}+00$ & $9.16 \mathrm{E}-01$ & $1.40 E+00$ \\
\hline \multicolumn{7}{|c|}{ Rad Chem (Ci/gal.) } \\
\hline${ }^{137} \mathrm{Cs}$ & $4.88 \mathrm{E}+00$ & $2.62 \mathrm{E}+00$ & $1.41 \mathrm{E}+00$ & $9.06 \mathrm{E}-01$ & $4.27 \mathrm{E}-01$ & $1.92 \mathrm{E}-01$ \\
\hline${ }^{90} \mathrm{Sr}$ & 1.87E-04 & $<1.05 E-04$ & $=2.93 E-05$ & $<2.71 E-05$ & 2.31E-05 & $6.58 \mathrm{E}-04$ \\
\hline \multicolumn{7}{|c|}{ ICP-MS (mol/L) } \\
\hline Mass $235(U)$ & $<1.25 E-06$ & $<1.25 E-06$ & $=4.00 E-07$ & $<3.23 E-07$ & $<2.40 E-07$ & $<1.79 E-07$ \\
\hline Mass $236(U)$ & $<1.25 E-06$ & $<1.25 E-06$ & $=3.99 E-07$ & $<3.21 E-07$ & $<2.39 E-07$ & $<1.78 E-07$ \\
\hline Mass $237(\mathrm{~Np})$ & $<1.24 E-06$ & $<1.24 E-06$ & - 3.97E-07 & $<3.20 E-07$ & $<2.38 E-07$ & $<1.78 E-07$ \\
\hline Mass $238(\mathrm{U}, \mathrm{Pu})$ & $1.23 \mathrm{E}-05$ & $1.01 \mathrm{E}-05$ & 2.31E-05 & 1.63E-05 & $1.23 \mathrm{E}-06$ & $2.14 \mathrm{E}-06$ \\
\hline Mass $239(\mathrm{Pu})$ & $<1.23 E-06$ & $<1.23 E-06$ & - 3.94E-07 & $<3.17 E-07$ & $<2.36 E-07$ & $<1.76 E-07$ \\
\hline Mass $99(\mathrm{Tc})$ & $1.87 \mathrm{E}-04$ & 1.11E-04 & 5.95E-05 & 3.69E-05 & 2.06E-05 & $9.65 \mathrm{E}-06$ \\
\hline
\end{tabular}


Table 7 Continued

\begin{tabular}{|c|c|c|c|c|c|c|}
\hline Wash \# & 7 & 8 & 9 & 10 & 2 & 4 \\
\hline \multicolumn{7}{|c|}{ IC Anions (mol/L) } \\
\hline $\mathrm{NO}_{3}^{-}$ & $2.94 E+00$ & 4.00E-01 & 2.30E-02 & $<8.57 E-03$ & n.d. & $4.70 E+00$ \\
\hline $\mathrm{NO}_{2}^{-}$ & 3.02E-02 & $1.47 \mathrm{E}-02$ & 8.08E-03 & 8.20E-03 & n.d. & 2.11E-01 \\
\hline $\mathrm{SO}_{4}{ }^{2-}$ & 4.79E-01 & $3.28 \mathrm{E}-01$ & 3.38E-02 & $<2.77 E-03$ & n.d. & 2.89E-01 \\
\hline $\mathrm{PO}_{4}{ }^{3-}$ & $<5.90 E-03$ & $<5.76 E-03$ & $<6.21 E-03$ & $<5.60 E-03$ & n.d. & $<5.83 E-02$ \\
\hline $\mathrm{Cl}^{-}$ & $<3.16 E-03$ & $<3.08 E-03$ & $<3.33 E-03$ & $<3.00 E-03$ & n.d. & $<3.12 E-02$ \\
\hline $\mathrm{F}^{-}$ & $<5.90 E-03$ & $<5.75 E-03$ & $<6.21 E-03$ & $<5.60 E-03$ & n.d. & $<5.83 E-02$ \\
\hline $\mathrm{C}_{2} \mathrm{O}_{4}{ }^{2-}$ & $5.29 \mathrm{E}-03$ & 1.94E-02 & $<6.71 E-03$ & $<6.04 E-03$ & n.d. & $<6.29 E-02$ \\
\hline $\mathrm{CHO}_{2}^{-}$ & $<1.25 E-02$ & $<1.21 E-02$ & $<1.31 E-02$ & $<1.18 E-02$ & n.d. & $<1.23 E-01$ \\
\hline \multicolumn{7}{|c|}{ Wet Chemistry (mol/L) } \\
\hline Total Base & $2.28 \mathrm{E}+00$ & $1.58 \mathrm{E}+00$ & $5.34 \mathrm{E}-02$ & $-2.40 \mathrm{E}-02$ & $3.30 \mathrm{E}+00$ & $3.18 \mathrm{E}+00$ \\
\hline $\mathrm{CO}_{3}^{2-}$ & $1.59 \mathrm{E}+00$ & $1.31 \mathrm{E}+00$ & $4.26 \mathrm{E}-02$ & $<1.06 E-02$ & $3.80 \mathrm{E}-01$ & $1.07 E+00$ \\
\hline Free $\mathrm{OH}$ (measured) & $5.22 \mathrm{E}-02$ & $-1.87 \mathrm{E}-02$ & $-3.51 E-04$ & $-3.05 E-02$ & $-9.29 E-01$ & $1.46 \mathrm{E}-01$ \\
\hline Free $\mathrm{OH}$ (calculated) & $6.54 \mathrm{E}-01$ & 2.66E-01 & $0.00 \mathrm{E}+00$ & $0.00 \mathrm{E}+00$ & $1.02 \mathrm{E}+00$ & $1.36 \mathrm{E}+00$ \\
\hline \multicolumn{7}{|c|}{ Rad Chem (Ci/gal.) } \\
\hline${ }^{137} \mathrm{Cs}$ & $6.42 \mathrm{E}-02$ & 1.30E-02 & $2.03 E-03$ & $3.16 \mathrm{E}-03$ & $2.72 E+00$ & $8.29 \mathrm{E}-01$ \\
\hline${ }^{90} \mathrm{Sr}$ & 7.17E-02 & 1.63E-01 & 3.77E-03 & 5.96E-04 & $<1.05 E-04$ & $<2.71 E-05$ \\
\hline \multicolumn{7}{|c|}{ ICP-MS (mol/L) } \\
\hline Mass $235(U)$ & 9.89E-08 & 7.53E-08 & 3.54E-07 & $6.10 \mathrm{E}-08$ & $<1.25 E-06$ & $<3.23 E-07$ \\
\hline Mass $236(U)$ & $5.13 E-08$ & $<3.94 E-08$ & $1.54 \mathrm{E}-07$ & $<3.83 E-08$ & $<1.25 E-06$ & $<3.21 E-07$ \\
\hline Mass $237(\mathrm{~Np})$ & 7.91E-08 & $1.29 \mathrm{E}-07$ & $<4.23 E-08$ & $<3.81 E-08$ & $<1.24 E-06$ & $<3.20 E-07$ \\
\hline Mass $238(\mathrm{U}, \mathrm{Pu})$ & $5.42 \mathrm{E}-07$ & 8.58E-07 & 1.30E-06 & $5.42 \mathrm{E}-07$ & 2.20E-05 & 4.71E-06 \\
\hline Mass $239(\mathrm{Pu})$ & $<3.99 E-08$ & 4.49E-08 & $<4.20 E-08$ & $<3.78 E-08$ & $<1.23 E-06$ & $<3.17 E-07$ \\
\hline Mass $99(\mathrm{Tc})$ & 3.84E-06 & 1.14E-06 & $5.71 \mathrm{E}-07$ & $<1.83 E-07$ & 1.09E-04 & 3.80E-05 \\
\hline
\end{tabular}


WSRC-TR-2002-00388

Revision 0

Table 8: Mass Removed (in Grams) During the Dissolution of $60.764 \mathrm{~g}$ of As-Received Tank $31 \mathrm{H}$ Saltcake by Multiple Washes with Inhibited Water

\begin{tabular}{|l|rrrrrr|}
\hline Wash \# & \multicolumn{1}{|c}{1} & \multicolumn{1}{c}{2} & \multicolumn{1}{c}{3} & \multicolumn{1}{c|}{4} & 5 & 6 \\
\hline $\mathrm{Na}^{+}$ & $1.31 \mathrm{E}+00$ & $2.14 \mathrm{E}+00$ & $1.81 \mathrm{E}+00$ & $2.29 \mathrm{E}+00$ & $2.55 \mathrm{E}+00$ & $2.56 \mathrm{E}+00$ \\
$\mathrm{OH}^{-}$ & $5.25 \mathrm{E}-02$ & $0.00 \mathrm{E}+00$ & $2.52 \mathrm{E}-02$ & $1.39 \mathrm{E}-02$ & $0.00 \mathrm{E}+00$ & $0.00 \mathrm{E}+00$ \\
$\mathrm{NO}_{3}{ }^{-}$ & $1.25 \mathrm{E}+00$ & $2.58 \mathrm{E}+00$ & $2.30 \mathrm{E}+00$ & $3.05 \mathrm{E}+00$ & $3.02 \mathrm{E}+00$ & $3.62 \mathrm{E}+00$ \\
$\mathrm{NO}_{2}{ }^{-}$ & $2.48 \mathrm{E}-01$ & $2.58 \mathrm{E}-01$ & $1.19 \mathrm{E}-01$ & $9.83 \mathrm{E}-02$ & $4.86 \mathrm{E}-02$ & $2.60 \mathrm{E}-02$ \\
$\left.\mathrm{Al}^{(\mathrm{OH}}\right)_{4}^{-}$ & $1.29 \mathrm{E}+00$ & $1.82 \mathrm{E}+00$ & $9.61 \mathrm{E}-01$ & $8.00 \mathrm{E}-01$ & $4.80 \mathrm{E}-01$ & $1.81 \mathrm{E}-01$ \\
$\mathrm{CO}_{3}{ }^{2-}$ & $7.65 \mathrm{E}-02$ & $2.69 \mathrm{E}-01$ & $4.62 \mathrm{E}-01$ & $7.49 \mathrm{E}-01$ & $8.32 \mathrm{E}-01$ & $4.12 \mathrm{E}-01$ \\
$\mathrm{SO}_{4}{ }^{2-}$ & $4.74 \mathrm{E}-02$ & $1.45 \mathrm{E}-01$ & $1.54 \mathrm{E}-01$ & $2.93 \mathrm{E}-01$ & $3.12 \mathrm{E}-01$ & $4.07 \mathrm{E}-01$ \\
$\mathrm{PO}_{4}{ }^{3-}$ & $6.49 \mathrm{E}-03$ & $7.35 \mathrm{E}-03$ & $3.76 \mathrm{E}-03$ & $2.94 \mathrm{E}-03$ & $2.07 \mathrm{E}-03$ & $1.69 \mathrm{E}-03$ \\
$\mathrm{CrO}_{4}{ }^{2-}$ & $2.25 \mathrm{E}-03$ & $2.20 \mathrm{E}-03$ & $1.05 \mathrm{E}-03$ & $8.06 \mathrm{E}-04$ & $5.24 \mathrm{E}-04$ & $2.65 \mathrm{E}-04$ \\
$\mathrm{MoO}_{4}{ }^{2-}$ & $1.73 \mathrm{E}-03$ & $2.27 \mathrm{E}-03$ & $9.54 \mathrm{E}-04$ & $8.45 \mathrm{E}-04$ & $6.12 \mathrm{E}-04$ & $2.95 \mathrm{E}-04$ \\
$\mathrm{SiO}_{3}{ }^{2-}$ & $<4.65 \mathrm{E}-04$ & $<7.89 \mathrm{E}-04$ & $7.67 \mathrm{E}-04$ & $7.32 \mathrm{E}-04$ & $4.62 \mathrm{E}-04$ & $<1.41 \mathrm{E}-04$ \\
$\mathrm{C}_{2} \mathrm{O}_{4}{ }^{2-}$ & $1.03 \mathrm{E}-01$ & $1.74 \mathrm{E}-01$ & $4.81 \mathrm{E}-02$ & $5.59 \mathrm{E}-02$ & $3.96 \mathrm{E}-02$ & $3.12 \mathrm{E}-02$ \\
$\mathrm{Cu}^{\mathrm{Sn}}$ & $1.33 \mathrm{E}-04$ & $2.20 \mathrm{E}-04$ & $6.15 \mathrm{E}-05$ & $6.07 \mathrm{E}-05$ & $5.43 \mathrm{E}-05$ & $3.81 \mathrm{E}-05$ \\
${ }^{137} \mathrm{Cs}^{90}$ & $7.38 \mathrm{E}-04$ & $1.09 \mathrm{E}-03$ & $4.90 \mathrm{E}-04$ & $5.04 \mathrm{E}-04$ & $4.99 \mathrm{E}-04$ & $4.46 \mathrm{E}-04$ \\
${ }^{238}$ & $8.81 \mathrm{E}-05$ & $8.16 \mathrm{E}-05$ & $3.72 \mathrm{E}-05$ & $2.95 \mathrm{E}-05$ & $1.55 \mathrm{E}-05$ & $7.34 \mathrm{E}-06$ \\
${ }^{99} \mathrm{Tc}$ & $2.16 \mathrm{E}-09$ & $<2.06 \mathrm{E}-09$ & $<4.94 \mathrm{E}-10$ & $<5.89 \mathrm{E}-10$ & $5.34 \mathrm{E}-10$ & $1.61 \mathrm{E}-08$ \\
& $1.73 \mathrm{E}-05$ & $3.85 \mathrm{E}-05$ & $4.79 \mathrm{E}-05$ & $2.79 \mathrm{E}-05$ & $3.49 \mathrm{E}-06$ & $6.43 \mathrm{E}-06$ \\
& $1.10 \mathrm{E}-04$ & $1.10 \mathrm{E}-04$ & $5.12 \mathrm{E}-05$ & $4.15 \mathrm{E}-05$ & $2.44 \mathrm{E}-05$ & $1.20 \mathrm{E}-05$ \\
\hline
\end{tabular}


Table 8 Continued

\begin{tabular}{|l|cccc|c|c|}
\hline Wash \# & 7 & 8 & 9 & 10 & Total & \multicolumn{1}{c|}{ Solids } \\
\hline $\mathrm{Na}^{+}$ & $1.96 \mathrm{E}+00$ & $1.92 \mathrm{E}+00$ & $1.32 \mathrm{E}-01$ & $4.05 \mathrm{E}-03$ & $1.67 \mathrm{E}+01$ & $1.30 \mathrm{E}-02$ \\
$\mathrm{OH}^{-}$ & $7.22 \mathrm{E}-03$ & $0.00 \mathrm{E}+00$ & $0.00 \mathrm{E}+00$ & $0.00 \mathrm{E}+00$ & $9.87 \mathrm{E}-02$ & n.d. \\
$\mathrm{NO}_{3}{ }^{-}$ & $1.71 \mathrm{E}+00$ & $4.05 \mathrm{E}-01$ & $4.21 \mathrm{E}-02$ & $<2.37 \mathrm{E}-02$ & $1.80 \mathrm{E}+01$ & n.d. \\
$\mathrm{NO}_{2}{ }^{-}$ & $9.69 \mathrm{E}-03$ & $3.94 \mathrm{E}-03$ & $0.00 \mathrm{E}+00$ & $0.00 \mathrm{E}+00$ & $8.12 \mathrm{E}-01$ & n.d. \\
$\mathrm{Al}(\mathrm{OH})_{4}{ }^{-}$ & $3.34 \mathrm{E}-02$ & $8.57 \mathrm{E}-03$ & $3.39 \mathrm{E}-03$ & $3.57 \mathrm{E}-03$ & $5.58 \mathrm{E}+00$ & $8.80 \mathrm{E}-01$ \\
$\mathrm{CO}_{3}{ }^{2-}$ & $8.98 \mathrm{E}-01$ & $1.28 \mathrm{E}+00$ & $7.53 \mathrm{E}-02$ & $<2.84 \mathrm{E}-02$ & $5.05 \mathrm{E}+00$ & n.d. \\
$\mathrm{SO}_{4}{ }^{2-}$ & $4.94 \mathrm{E}-01$ & $8.74 \mathrm{E}-01$ & $6.41 \mathrm{E}-02$ & $2.79 \mathrm{E}-03$ & $2.79 \mathrm{E}+00$ & $1.83 \mathrm{E}-02$ \\
$\mathrm{PO}_{4}{ }^{3-}$ & $8.91 \mathrm{E}-04$ & $1.26 \mathrm{E}-03$ & $<3.68 \mathrm{E}-04$ & $<5.01 \mathrm{E}-04$ & $2.68 \mathrm{E}-02$ & $0.00 \mathrm{E}+00$ \\
$\mathrm{CrO}_{4}{ }^{2-}$ & $1.17 \mathrm{E}-04$ & $1.12 \mathrm{E}-04$ & $<2.33 \mathrm{E}-05$ & $<3.17 \mathrm{E}-05$ & $7.34 \mathrm{E}-03$ & $1.16 \mathrm{E}-03$ \\
$\mathrm{MoO}_{4}{ }^{2-}$ & $1.07 \mathrm{E}-04$ & $7.88 \mathrm{E}-05$ & $<1.54 \mathrm{E}-04$ & $<2.09 \mathrm{E}-04$ & $6.89 \mathrm{E}-03$ & $0.00 \mathrm{E}+00$ \\
$\mathrm{SiO}_{3}{ }^{2-}$ & $1.20 \mathrm{E}-04$ & $7.66 \mathrm{E}-05$ & $<7.86 \mathrm{E}-05$ & $8.78 \mathrm{E}-04$ & $3.04 \mathrm{E}-03$ & $1.89 \mathrm{E}-02$ \\
$\mathrm{C}_{2} \mathrm{O}_{4}{ }^{2-}$ & $4.38 \mathrm{E}-03$ & $2.78 \mathrm{E}-02$ & $<1.74 \mathrm{E}-02$ & $<2.37 \mathrm{E}-02$ & $3.22 \mathrm{E}-02$ & n.d. \\
$\mathrm{Cu}^{\mathrm{Sn}}$ & $7.38 \mathrm{E}-06$ & $1.32 \mathrm{E}-05$ & $2.38 \mathrm{E}-05$ & $3.50 \mathrm{E}-05$ & $6.11 \mathrm{E}-04$ & $2.21 \mathrm{E}-04$ \\
$\mathrm{Sn}^{137} \mathrm{Cs}$ & $1.98 \mathrm{E}-04$ & $2.72 \mathrm{E}-04$ & $<7.821 \mathrm{E}-05$ & $1.87 \mathrm{E}-04$ & $4.43 \mathrm{E}-03$ & $5.14 \mathrm{E}-03$ \\
${ }^{90} \mathrm{Sr}$ & $1.83 \mathrm{E}-06$ & $6.44 \mathrm{E}-07$ & $1.81 \mathrm{E}-07$ & $4.27 \mathrm{E}-07$ & $2.62 \mathrm{E}-04$ & $2.34 \mathrm{E}-06$ \\
${ }^{238} \mathrm{U}$ & $1.31 \mathrm{E}-06$ & $5.15 \mathrm{E}-06$ & $2.15 \mathrm{E}-07$ & $5.14 \mathrm{E}-08$ & $6.74 \mathrm{E}-06$ & $1.05 \mathrm{E}-05$ \\
${ }^{99} \mathrm{Tc}$ & $1.21 \mathrm{E}-06$ & $3.33 \mathrm{E}-06$ & $9.12 \mathrm{E}-06$ & $5.74 \mathrm{E}-06$ & $1.55 \mathrm{E}-04$ & $1.09 \mathrm{E}-04$ \\
& $3.57 \mathrm{E}-06$ & $1.85 \mathrm{E}-06$ & $1.66 \mathrm{E}-06$ & $<8.05 \mathrm{E}-07$ & $3.56 \mathrm{E}-04$ & $3.24 \mathrm{E}-05$ \\
\hline
\end{tabular}


WSRC-TR-2002-00388

Revision 0

Table 9: Test Data and ICP-ES Results for Tank 31H Salt Dissolution with HLW Supernate (from Tanks 21H/24H/26F)

\begin{tabular}{|c|c|c|c|c|c|c|}
\hline Wash \# & 1 & 2 & 3 & 4 & 5 & 6 \\
\hline $\begin{array}{l}\text { Diluent/Saltcake } \\
\text { (cumulative mass basis) }\end{array}$ & 0.122 & 0.247 & 0.397 & 0.643 & 0.895 & 1.145 \\
\hline Supernate Removed (g) & 5.8 & 10.1 & 12.8 & 19.6 & 21.0 & 20.9 \\
\hline Supernate (vol. \%) & 11.1 & 13.9 & 25.6 & 35.4 & 37.2 & 40.5 \\
\hline Undissolved Salt (wt \%) & 102.7 & 98.7 & 92.6 & 85.1 & 75.8 & 66.6 \\
\hline Supernate Density $\left(\mathrm{g} / \mathrm{cm}^{3}\right)$ & 1.455 & 1.465 & 1.455 & 1.454 & 1.440 & 1.462 \\
\hline Est. Solid Density $\left(\mathrm{g} / \mathrm{cm}^{3}\right)$ & 1.96 & 1.94 & 1.95 & 1.96 & 1.89 & 1.85 \\
\hline Charge Balance $(-/+)(\%)$ & 103 & 96 & 97 & 97 & 98 & 92 \\
\hline \multicolumn{7}{|c|}{ ICP-ES (mol/L) } \\
\hline $\mathrm{Ag}$ & $<1.21 E-04$ & $<1.63 E-04$ & $<1.60 E-04$ & $<1.04 E-04$ & $<5.58 E-05$ & $<8.66 E-05$ \\
\hline $\mathrm{Al}$ & $1.79 E+00$ & $1.53 \mathrm{E}+00$ & $1.65 \mathrm{E}+00$ & $1.20 \mathrm{E}+00$ & $1.09 \mathrm{E}+00$ & 7.44E-01 \\
\hline$B$ & $1.47 \mathrm{E}-02$ & 1.54E-02 & 1.41E-02 & $1.52 \mathrm{E}-02$ & 1.43E-02 & $1.48 \mathrm{E}-02$ \\
\hline $\mathrm{Ba}$ & $<2.25 E-04$ & $<3.03 E-04$ & $<2.98 E-04$ & $<1.94 E-04$ & $<1.04 E-04$ & $<1.61 E-04$ \\
\hline $\mathrm{Ca}$ & $<9.32 E-04$ & $<1.26 E-03$ & $<1.24 E-03$ & $<8.07 E-04$ & $<4.32 E-04$ & $<6.70 E-04$ \\
\hline $\mathrm{Cd}$ & $<6.07 E-05$ & $<8.19 E-05$ & $<8.06 E-05$ & $<5.25 E-05$ & $<2.81 E-05$ & $<4.36 E-05$ \\
\hline $\mathrm{Ce}$ & 4.74E-04 & $<4.22 E-04$ & $<4.15 E-04$ & $<2.71 E-04$ & $<1.45 E-04$ & $<2.25 E-04$ \\
\hline $\mathrm{Cr}$ & $5.28 \mathrm{E}-03$ & 4.15E-03 & 3.23E-03 & 3.03E-03 & $2.74 \mathrm{E}-03$ & $2.78 \mathrm{E}-03$ \\
\hline $\mathrm{Cu}$ & 4.04E-04 & 5.24E-04 & 5.16E-04 & 3.89E-04 & 3.04E-04 & $3.51 \mathrm{E}-04$ \\
\hline $\mathrm{Fe}$ & 2.71E-04 & $1.88 \mathrm{E}-04$ & 2.39E-04 & 2.04E-04 & 2.79E-04 & 2.03E-04 \\
\hline $\mathrm{Gd}$ & $<2.42 E-04$ & $<3.26 E-04$ & $<3.21 E-04$ & $<2.09 E-04$ & $<1.12 E-04$ & $<1.74 E-04$ \\
\hline $\mathrm{K}$ & 6.48E-02 & $<5.26 E-02$ & $<5.17 E-02$ & 4.78E-02 & 4.16E-02 & 3.82E-02 \\
\hline La & $<8.42 E-05$ & $<1.14 E-04$ & $<1.12 E-04$ & $<7.29 E-05$ & $<3.90 E-05$ & $<6.05 E-05$ \\
\hline $\mathrm{Li}$ & $\mid<1.01 E-02$ & $<1.36 E-02$ & $<1.34 E-02$ & $<8.71 E-03$ & $<4.66 E-03$ & $<7.23 E-03$ \\
\hline $\mathrm{Mg}$ & $\mid<3.54 E-04$ & $<4.78 E-04$ & $<4.70 E-04$ & $<3.07 E-04$ & $<1.64 E-04$ & $<2.55 E-04$ \\
\hline $\mathrm{Mn}$ & $<2.37 E-05$ & $<3.19 E-05$ & $<3.14 E-05$ & $<2.05 E-05$ & $<1.10 E-05$ & $<1.70 E-05$ \\
\hline Mo & 2.71E-03 & 1.67E-03 & 1.17E-03 & $9.14 \mathrm{E}-04$ & $1.00 \mathrm{E}-03$ & 7.79E-04 \\
\hline $\mathrm{Na}$ & $1.08 \mathrm{E}+01$ & $1.02 E+01$ & $1.02 \mathrm{E}+01$ & $1.00 \mathrm{E}+01$ & $9.56 \mathrm{E}+00$ & $1.00 \mathrm{E}+01$ \\
\hline $\mathrm{Ni}$ & $<3.74 E-04$ & $<5.04 E-04$ & $<4.96 E-04$ & $<3.23 E-04$ & $<1.73 E-04$ & $<2.68 E-04$ \\
\hline$P$ & $1.55 \mathrm{E}-02$ & 1.14E-02 & $9.88 \mathrm{E}-03$ & 5.72E-03 & 4.96E-03 & 4.90E-03 \\
\hline $\mathrm{Pb}$ & $<2.50 E-04$ & $<3.37 E-04$ & $<3.32 E-04$ & $<2.16 E-04$ & $<1.16 E-04$ & $<1.80 E-04$ \\
\hline$S$ & 5.47E-02 & 6.28E-02 & 7.67E-02 & $1.01 \mathrm{E}-01$ & 9.37E-02 & $1.12 \mathrm{E}-01$ \\
\hline $\mathrm{Sb}$ & $<5.04 E-03$ & $<6.80 E-03$ & $<6.69 E-03$ & $<4.36 E-03$ & $<2.34 E-03$ & $<3.62 E-03$ \\
\hline $\mathrm{Si}$ & $1.40 \mathrm{E}-03$ & $<1.30 E-03$ & $<1.28 E-03$ & 9.31E-04 & 1.83E-03 & 7.06E-04 \\
\hline Sn & 1.37E-03 & $<8.31 E-04$ & $1.06 \mathrm{E}-03$ & $<5.33 E-04$ & 4.67E-04 & 4.68E-04 \\
\hline $\mathrm{Sr}$ & $<1.41 E-04$ & $<1.90 E-04$ & $<1.87 E-04$ & $<1.22 E-04$ & $<6.53 E-05$ & $<1.01 E-04$ \\
\hline $\mathrm{Ti}$ & $<2.61 E-04$ & $<3.52 E-04$ & $<3.47 E-04$ & $<2.26 E-04$ & $<1.21 E-04$ & $<1.88 E-04$ \\
\hline$U$ & $<1.55 E-03$ & $<2.09 E-03$ & $<2.06 E-03$ & $<1.34 E-03$ & $<7.18 E-04$ & $<1.11 E-03$ \\
\hline $\mathrm{Zn}$ & 4.00E-04 & 2.71E-04 & 3.00E-04 & 2.62E-04 & 2.27E-04 & 2.87E-04 \\
\hline $\mathrm{Zr}$ & $<4.06 E-04$ & $<5.48 E-04$ & $<5.39 E-04$ & $<3.51 E-04$ & $<1.88 E-04$ & $<2.92 E-04$ \\
\hline
\end{tabular}


Table 9 Continued

\begin{tabular}{|c|c|c|c|c|c|}
\hline Wash \# & 7 & 8 & 9 & 10 & 2 \\
\hline $\begin{array}{l}\text { Diluent/Saltcake } \\
\text { (cumulative mass basis) }\end{array}$ & 1.395 & 1.890 & 2.469 & 3.315 & \multirow{7}{*}{ duplicate } \\
\hline Supernate Removed (g) & 22.3 & 39.0 & 44.7 & 57.5 & \\
\hline Supernate (vol. \%) & 47.1 & 66.7 & 81.0 & 87.8 & \\
\hline Undissolved Salt (wt \%) & 55.2 & 40.9 & 25.6 & 16.0 & \\
\hline Supernate Density $\left(\mathrm{g} / \mathrm{cm}^{3}\right)$ & 1.421 & 1.387 & 1.367 & 1.345 & \\
\hline Est. Solid Density $\left(\mathrm{g} / \mathrm{cm}^{3}\right)$ & 1.87 & 1.78 & 1.95 & 1.63 & \\
\hline Charge Balance $(-/+)(\%)$ & 97 & 98 & 99 & 96 & \\
\hline \multicolumn{6}{|c|}{ ICP-ES (mol/L) } \\
\hline $\mathrm{Ag}$ & $<3.62 E-05$ & $<3.77 E-05$ & $<2.50 E-05$ & $<2.36 E-05$ & $<1.63 E-04<1.04 E-04$ \\
\hline $\mathrm{Al}$ & $5.58 \mathrm{E}-01$ & 3.09E-01 & $2.61 \mathrm{E}-01$ & $2.51 \mathrm{E}-01$ & $1.54 \mathrm{E}+00 \quad 1.20 \mathrm{E}+00$ \\
\hline B & $1.43 \mathrm{E}-02$ & 1.47E-02 & $1.53 \mathrm{E}-02$ & 1.61E-02 & 1.47E-02 1.48E-02 \\
\hline $\mathrm{Ba}$ & $<6.76 E-05$ & $<7.04 E-05$ & $<4.65 E-05$ & $<4.41 E-05$ & $<3.03 E-04<1.94 E-04$ \\
\hline $\mathrm{Ca}$ & $<2.80 E-04$ & $<2.92 E-04$ & $<1.93 E-04$ & $<1.83 E-04$ & $<1.26 E-03<8.07 E-04$ \\
\hline $\mathrm{Cd}$ & $<1.83 E-05$ & $<1.90 E-05$ & $<1.26 E-05$ & $<1.19 E-05$ & $<8.19 E-05<5.25 E-05$ \\
\hline $\mathrm{Ce}$ & $<9.41 E-05$ & $<9.81 E-05$ & $<6.48 E-05$ & $<6.14 E-05$ & $<4.22 E-04<2.71 E-04$ \\
\hline $\mathrm{Cr}$ & 2.64E-03 & $2.62 \mathrm{E}-03$ & 2.80E-03 & 2.94E-03 & 4.05E-03 2.87E-03 \\
\hline $\mathrm{Cu}$ & $2.44 \mathrm{E}-04$ & $2.55 \mathrm{E}-04$ & $2.21 \mathrm{E}-04$ & $2.24 \mathrm{E}-04$ & 5.35E-04 3.98E-04 \\
\hline $\mathrm{Fe}$ & 2.17E-04 & $2.21 \mathrm{E}-04$ & $1.66 \mathrm{E}-04$ & $2.24 \mathrm{E}-04$ & $2.12 \mathrm{E}-04 \quad 2.49 \mathrm{E}-04$ \\
\hline $\mathrm{Gd}$ & $<7.27 E-05$ & $<7.57 E-05$ & $<5.01 E-05$ & $<4.74 E-05$ & $<3.26 E-04<2.09 E-04$ \\
\hline $\mathrm{K}$ & 3.59E-02 & 4.00E-02 & 4.06E-02 & 3.84E-02 & $<5.26 E-02 \quad 4.10 \mathrm{E}-02$ \\
\hline La & $<2.53 E-05$ & $<2.64 E-05$ & $<1.74 E-05$ & $<1.65 E-05$ & $<1.14 E-04<7.29 E-05$ \\
\hline $\mathrm{Li}$ & $<3.03 E-03$ & $<3.15 E-03$ & $<2.08 E-03$ & $<1.97 E-03$ & $<1.36 E-02<8.71 E-03$ \\
\hline $\mathrm{Mg}$ & $<1.07 E-04$ & $<1.11 E-04$ & $<7.34 E-05$ & $<6.94 E-05$ & $<4.78 E-04<3.07 E-04$ \\
\hline $\mathrm{Mn}$ & $<7.11 E-06$ & $<7.41 E-06$ & $<4.90 E-06$ & $<4.64 E-06$ & $<3.19 E-05<2.05 E-05$ \\
\hline Mo & $6.82 \mathrm{E}-04$ & 6.68E-04 & 6.35E-04 & 6.64E-04 & 1.49E-03 9.39E-04 \\
\hline $\mathrm{Na}$ & $9.41 \mathrm{E}+00$ & $8.99 \mathrm{E}+00$ & $8.41 \mathrm{E}+00$ & $7.78 \mathrm{E}+00$ & $1.04 \mathrm{E}+01 \quad 9.89 \mathrm{E}+00$ \\
\hline $\mathrm{Ni}$ & $<1.12 E-04$ & $<1.17 E-04$ & $<7.74 E-05$ & $<7.32 E-05$ & $<5.04 E-04<3.23 E-04$ \\
\hline$P$ & $3.80 \mathrm{E}-03$ & $3.47 \mathrm{E}-03$ & 3.90E-03 & 4.11E-03 & 1.17E-02 7.81E-03 \\
\hline $\mathrm{Pb}$ & $<7.52 E-05$ & $<7.84 E-05$ & $<5.18 E-05$ & $<4.90 E-05$ & $<3.37 E-04<2.16 E-04$ \\
\hline$S$ & $1.12 \mathrm{E}-01$ & $1.35 \mathrm{E}-01$ & $1.32 \mathrm{E}-01$ & $1.42 \mathrm{E}-01$ & 6.31E-02 9.78E-02 \\
\hline $\mathrm{Sb}$ & $<1.52 E-03$ & $<1.58 E-03$ & $<1.04 E-03$ & $<9.89 E-04$ & $<6.80 E-03<4.36 E-03$ \\
\hline $\mathrm{Si}$ & $1.48 \mathrm{E}-03$ & $1.27 \mathrm{E}-03$ & $1.22 \mathrm{E}-03$ & $1.36 \mathrm{E}-03$ & $<1.30 \mathrm{E}-03 \quad 1.03 \mathrm{E}-03$ \\
\hline Sn & 2.90E-04 & 2.17E-04 & 1.67E-04 & 1.94E-04 & $1.03 E-03<5.33 E-04$ \\
\hline $\mathrm{Sr}$ & $<4.24 E-05$ & $<4.41 E-05$ & $<2.92 E-05$ & $<2.76 E-05$ & $<1.90 E-04<1.22 E-04$ \\
\hline $\mathrm{Ti}$ & $<7.85 E-05$ & $<8.18 E-05$ & $<5.41 E-05$ & $<5.12 E-05$ & $<3.52 E-04<2.26 E-04$ \\
\hline$U$ & $<4.66 E-04$ & $<4.85 E-04$ & $<3.21 E-04$ & $<3.04 E-04$ & $<2.09 E-03<1.34 E-03$ \\
\hline $\mathrm{Zn}$ & $2.04 \mathrm{E}-04$ & $2.12 \mathrm{E}-04$ & 2.06E-04 & $2.25 \mathrm{E}-04$ & $2.95 \mathrm{E}-04 \quad 2.52 \mathrm{E}-04$ \\
\hline $\mathrm{Zr}$ & $<1.22 E-04$ & $<1.27 E-04$ & $<8.41 E-05$ & $<7.96 E-05$ & $<5.48 E-04<3.51 E-04$ \\
\hline
\end{tabular}


WSRC-TR-2002-00388

Revision 0

Table 10: Results from IC Anions, Wet Chemistry, Rad. Chem., and ICP-MS for Tank 31H Salt Dissolution with HLW Supernate (from Tanks 21H/24H/26F)

\begin{tabular}{|c|c|c|c|c|c|c|}
\hline Wash \# & 1 & 2 & 3 & 4 & 5 & 6 \\
\hline \multicolumn{7}{|c|}{ IC Anions (mol/L) } \\
\hline $\mathrm{NO}_{3}^{-}$ & $2.75 \mathrm{E}+00$ & $2.84 \mathrm{E}+00$ & $3.15 E+00$ & $3.15 \mathrm{E}+00$ & $3.22 \mathrm{E}+00$ & $3.46 \mathrm{E}+00$ \\
\hline $\mathrm{NO}_{2}^{-}$ & $1.38 \mathrm{E}+00$ & $1.12 \mathrm{E}+00$ & 8.95E-01 & 8.19E-01 & 8.00E-01 & 7.41E-01 \\
\hline $\mathrm{SO}_{4}{ }^{2-}$ & 2.71E-02 & 4.56E-02 & 4.71E-02 & 7.76E-02 & 7.21E-02 & 7.53E-02 \\
\hline $\mathrm{PO}_{4}^{3-}$ & $<1.71 E-01$ & $<2.31 E-01$ & 2.27E-01 & $<1.48 E-01$ & - 7.93E-02 & $<1.23 E-01$ \\
\hline $\mathrm{Cl}^{-}$ & $<9.17 E-02$ & $<1.24 E-01$ & $=1.22 E-01$ & $<7.93 E-02$ & = 4.25E-02 & $<6.58 E-02$ \\
\hline $\mathrm{F}^{-}$ & $<1.71 E-01$ & $<2.31 E-01$ & $=2.27 E-01$ & $<1.48 E-01$ & = $7.92 E-02$ & $<1.23 E-01$ \\
\hline $\mathrm{C}_{2} \mathrm{O}_{4}{ }^{2-}$ & $<1.85 E-01$ & $<2.49 E-01$ & $2.45 E-01$ & $<1.60 E-01$ & $8.55 E-02$ & $<1.33 E-01$ \\
\hline $\mathrm{CHO}_{2}^{-}$ & $\mid<3.61 E-01$ & $<4.87 E-01$ & - 4.79E-01 & $<3.12 E-01$ & = $1.67 E-01$ & $<2.59 E-01$ \\
\hline \multicolumn{7}{|c|}{ Wet Chemistry (mol/L) } \\
\hline Total Base & $6.84 \mathrm{E}+00$ & $5.71 \mathrm{E}+00$ & $5.62 E+00$ & $5.21 \mathrm{E}+00$ & $4.98 \mathrm{E}+00$ & $4.56 \mathrm{E}+00$ \\
\hline $\mathrm{CO}_{3}{ }^{2-}$ & $<3.25 E-01$ & $<4.38 E-01$ & 4.31E-01 & 2.09E-01 & 1.99E-01 & 2.45E-01 \\
\hline Free $\mathrm{OH}$ (measured) & 4.99E-01 & $3.08 \mathrm{E}+00$ & $1.31 E+00$ & $1.28 \mathrm{E}+00$ & $1.37 E+00$ & $1.18 \mathrm{E}+00$ \\
\hline Free $\mathrm{OH}$ (calculated) & $5.05 \mathrm{E}+00$ & 4.17E+00 & $3.97 E+00$ & $3.81 \mathrm{E}+00$ & $3.69 E+00$ & $3.57 E+00$ \\
\hline \multicolumn{7}{|c|}{ Rad Chem (Ci/gal.) } \\
\hline${ }^{137} \mathrm{Cs}$ & $6.25 E+00$ & $5.05 E+00$ & $3.87 E+00$ & $3.26 \mathrm{E}+00$ & $3.01 \mathrm{E}+00$ & $2.81 \mathrm{E}+00$ \\
\hline${ }^{90} \mathrm{Sr}$ & $1.35 \mathrm{E}-03$ & 8.85E-04 & 7.79E-04 & $9.18 \mathrm{E}-04$ & 8.70E-04 & 7.90E-04 \\
\hline \multicolumn{7}{|c|}{ ICP-MS (mol/L) } \\
\hline Mass $235(U)$ & $<1.73 E-06$ & $<2.33 E-06$ & = $2.29 E-06$ & $<1.50 E-06$ & = 8.01E-07 & $<1.24 E-06$ \\
\hline Mass $236(U)$ & $<1.72 E-06$ & $<2.32 E-06$ & $=2.28 E-06$ & $<1.49 E-06$ & = $7.97 E-07$ & $<1.24 E-06$ \\
\hline Mass $237(\mathrm{~Np})$ & $<1.71 E-06$ & $<2.31 E-06$ & ～2.27E-06 & $<1.48 E-06$ & - $7.94 E-07$ & $<1.23 E-06$ \\
\hline Mass $238(\mathrm{U}, \mathrm{Pu})$ & 3.16E-05 & 1.19E-04 & 3.74E-05 & 4.49E-05 & 3.96E-05 & 3.46E-05 \\
\hline Mass $239(\mathrm{Pu})$ & $<1.70 E-06$ & $<2.29 E-06$ & ２.26E-06 & $<1.47 E-06$ & - 7.87E-07 & $<1.22 E-06$ \\
\hline Mass $99(\mathrm{Tc})$ & 2.36E-04 & 1.92E-04 & $1.43 \mathrm{E}-04$ & $1.20 \mathrm{E}-04$ & $1.02 E-04$ & 9.65E-05 \\
\hline
\end{tabular}


Table 10 Continued

\begin{tabular}{|c|c|c|c|c|c|c|}
\hline Wash \# & 7 & 8 & 9 & 10 & 2 & 4 \\
\hline \multicolumn{7}{|c|}{ IC Anions (mol/L) } \\
\hline $\mathrm{NO}_{3}^{-}$ & $3.00 E+00$ & $2.83 E+00$ & $1.91 \mathrm{E}+00$ & 9.40E-01 & $2.84 \mathrm{E}+00$ & $3.15 E+00$ \\
\hline $\mathrm{NO}_{2}^{-}$ & 7.02E-01 & 7.74E-01 & 8.78E-01 & 8.58E-01 & $1.12 E+00$ & $8.22 E-01$ \\
\hline $\mathrm{SO}_{4}{ }^{2-}$ & 7.93E-02 & $1.07 \mathrm{E}-01$ & 1.06E-01 & $1.09 \mathrm{E}-01$ & 4.33E-02 & $6.73 E-02$ \\
\hline $\mathrm{PO}_{4}^{3-}$ & $<5.14 E-02<$ & $<5.36 E-02$ & $3.54 E-02$ & $<3.35 E-02$ & $<2.31 E-01$ & $<1.48 E-01$ \\
\hline $\mathrm{Cl}^{-}$ & $<2.76 E-02<$ & $<2.87 E-02$ & $=1.90 E-02$ & $<1.80 E-02$ & $<1.24 E-01$ & $<7.93 E-02$ \\
\hline $\mathrm{F}^{-}$ & $<5.14 E-02<$ & $<5.36 E-02$ & = $3.54 E-02$ & $<3.35 E-02$ & $<2.31 E-01$ & $<1.48 E-01$ \\
\hline $\mathrm{C}_{2} \mathrm{O}_{4}^{2-}$ & $<5.55 E-02<$ & $<5.78 E-02$ & 3.82E-02 & $<3.62 E-02$ & $<2.49 E-01$ & $<1.60 E-01$ \\
\hline $\mathrm{CHO}_{2}^{-}$ & $<1.09 E-01<$ & $<1.13 E-01$ & ～ $7.47 E-02$ & $<7.07 E-02$ & $<4.87 E-01$ & $<3.12 E-01$ \\
\hline \multicolumn{7}{|c|}{ Wet Chemistry (mol/L) } \\
\hline Total Base & $4.73 E+00$ & $4.44 \mathrm{E}+00$ & $4.66 \mathrm{E}+00$ & $4.74 \mathrm{E}+00$ & $4.70 \mathrm{E}+00$ & $4.24 \mathrm{E}+00$ \\
\hline $\mathrm{CO}_{3}{ }^{2-}$ & 4.55E-01 & 5.01E-01 & $5.72 \mathrm{E}-01$ & $3.12 \mathrm{E}-01$ & $<4.38 E-01$ & 2.43E-01 \\
\hline Free $\mathrm{OH}$ (measured) & $3.20 \mathrm{E}+00$ & $2.96 \mathrm{E}+00$ & $3.28 \mathrm{E}+00$ & $3.32 \mathrm{E}+00$ & $1.65 \mathrm{E}-01$ & 5.04E-01 \\
\hline Free $\mathrm{OH}$ (calculated) & $3.71 \mathrm{E}+00$ & $3.63 \mathrm{E}+00$ & $3.82 E+00$ & $4.49 \mathrm{E}+00$ & $3.16 \mathrm{E}+00$ & $2.80 \mathrm{E}+00$ \\
\hline \multicolumn{7}{|c|}{ Rad Chem (Ci/gal.) } \\
\hline${ }^{137} \mathrm{Cs}$ & $2.77 \mathrm{E}+00$ & $2.72 E+00$ & $2.90 \mathrm{E}+00$ & $3.13 E+00$ & $5.36 \mathrm{E}+00$ & $3.44 E+00$ \\
\hline${ }^{90} \mathrm{Sr}$ & 4.09E-03 & $1.57 \mathrm{E}-02$ & $2.15 \mathrm{E}-02$ & 4.33E-02 & 1.07E-03 & 1.10E-03 \\
\hline \multicolumn{7}{|c|}{ ICP-MS (mol/L) } \\
\hline Mass $235(\mathrm{U})$ & $<4.95 E-07<$ & $<5.15 E-07$ & $=3.41 E-07$ & $<3.22 E-07$ & $<2.22 E-06$ & $<1.42 E-06$ \\
\hline Mass $236(U)$ & $<4.93 E-07<$ & $<5.13 E-07$ & 3.39E-07 & $<3.21 E-07$ & $<2.21 E-06$ & $<1.42 E-06$ \\
\hline Mass $237(\mathrm{~Np})$ & $<4.91 E-07<$ & $<5.11 E-07$ & $=3.38 E-07$ & $<3.20 E-07$ & $<2.20 E-06$ & $<1.41 E-06$ \\
\hline Mass $238(\mathrm{U}, \mathrm{Pu})$ & 3.27E-05 & 3.31E-05 & 3.47E-05 & 3.69E-05 & 2.72E-05 & 2.92E-05 \\
\hline Mass $239(\mathrm{Pu})$ & $<4.86 E-07<$ & $<5.07 E-07$ & = 3.35E-07 & $<3.17 E-07$ & $<2.18 E-06$ & $<1.40 E-06$ \\
\hline Mass $99(\mathrm{Tc})$ & 8.85E-05 & 8.82E-05 & 8.66E-05 & 9.19E-05 & $1.85 \mathrm{E}-04$ & 1.09E-04 \\
\hline
\end{tabular}


WSRC-TR-2002-00388

Revision 0

Table 11: Mass Removed (in Grams) During the Dissolution of $61.052 \mathrm{~g}$ of As-Received Tank 31H Saltcake by Multiple Washes with HLW Supernate (from Tanks 21H/24H/26F)

\begin{tabular}{|l|rrrrrc|}
\hline Wash \# & \multicolumn{1}{|c}{1} & \multicolumn{1}{c}{2} & \multicolumn{1}{c}{3} & \multicolumn{1}{c}{4} & 5 & 6 \\
\hline $\mathrm{Na}^{+}$ & $2.97 \mathrm{E}-01$ & $9.08 \mathrm{E}-01$ & $1.22 \mathrm{E}+00$ & $1.69 \mathrm{E}+00$ & $1.78 \mathrm{E}+00$ & $1.87 \mathrm{E}+00$ \\
$\mathrm{OH}^{-}$ & $0.00 \mathrm{E}+00$ & $0.00 \mathrm{E}+00$ & $0.00 \mathrm{E}+00$ & $0.00 \mathrm{E}+00$ & $0.00 \mathrm{E}+00$ & $0.00 \mathrm{E}+00$ \\
$\mathrm{NO}_{3}{ }^{-}$ & $4.00 \mathrm{E}-01$ & $9.21 \mathrm{E}-01$ & $1.38 \mathrm{E}+00$ & $2.07 \mathrm{E}+00$ & $2.33 \mathrm{E}+00$ & $2.49 \mathrm{E}+00$ \\
$\mathrm{NO}_{2}{ }^{-}$ & $4.91 \mathrm{E}-02$ & $1.44 \mathrm{E}-01$ & $1.13 \mathrm{E}-01$ & $9.61 \mathrm{E}-02$ & $1.15 \mathrm{E}-01$ & $6.62 \mathrm{E}-02$ \\
$\mathrm{Al}(\mathrm{OH})_{4}{ }^{-}$ & $5.67 \mathrm{E}-01$ & $8.91 \mathrm{E}-01$ & $1.24 \mathrm{E}+00$ & $1.31 \mathrm{E}+00$ & $1.28 \mathrm{E}+00$ & $7.79 \mathrm{E}-01$ \\
$\mathrm{CO}_{3}{ }^{2-}$ & $<7.79 \mathrm{E}-02$ & $<1.81 \mathrm{E}-01$ & $<2.28 \mathrm{E}-01$ & $1.83 \mathrm{E}-01$ & $1.75 \mathrm{E}-01$ & $2.10 \mathrm{E}-01$ \\
$\mathrm{SO}_{4}{ }^{2-}$ & $1.26 \mathrm{E}-02$ & $3.29 \mathrm{E}-02$ & $5.47 \mathrm{E}-02$ & $1.12 \mathrm{E}-01$ & $1.14 \mathrm{E}-01$ & $1.37 \mathrm{E}-01$ \\
$\mathrm{PO}_{4}{ }^{3-}$ & $3.91 \mathrm{E}-03$ & $5.50 \mathrm{E}-03$ & $5.86 \mathrm{E}-03$ & $4.67 \mathrm{E}-03$ & $2.79 \mathrm{E}-03$ & $2.57 \mathrm{E}-03$ \\
$\mathrm{CrO}_{4}{ }^{2-}$ & $7.78 \mathrm{E}-04$ & $1.55 \mathrm{E}-03$ & $1.27 \mathrm{E}-03$ & $1.24 \mathrm{E}-03$ & $1.19 \mathrm{E}-03$ & $1.18 \mathrm{E}-03$ \\
$\mathrm{MoO}_{4}{ }^{2-}$ & $1.27 \mathrm{E}-03$ & $1.26 \mathrm{E}-03$ & $1.08 \mathrm{E}-03$ & $1.06 \mathrm{E}-03$ & $1.38 \mathrm{E}-03$ & $8.21 \mathrm{E}-04$ \\
$\mathrm{SiO}_{3}{ }^{2-}$ & $0.00 \mathrm{E}+00$ & $<1.74 \mathrm{E}-04$ & $<2.57 \mathrm{E}-04$ & $8.86 \mathrm{E}-06$ & $1.02 \mathrm{E}-03$ & $0.00 \mathrm{E}+00$ \\
$\mathrm{Cu}^{\mathrm{Sn}}$ & $4.12 \mathrm{E}-05$ & $1.68 \mathrm{E}-04$ & $2.14 \mathrm{E}-04$ & $2.14 \mathrm{E}-04$ & $1.56 \mathrm{E}-04$ & $1.92 \mathrm{E}-04$ \\
${ }^{137} \mathrm{Cs}$ & $6.49 \mathrm{E}-04$ & $<8.43 \mathrm{E}-04$ & $1.11 \mathrm{E}-03$ & $<8.54 \mathrm{E}-04$ & $8.10 \mathrm{E}-04$ & $7.94 \mathrm{E}-04$ \\
${ }^{90} \mathrm{Sr}$ & $2.72 \mathrm{E}-05$ & $5.86 \mathrm{E}-05$ & $4.42 \mathrm{E}-05$ & $3.91 \mathrm{E}-05$ & $3.33 \mathrm{E}-05$ & $2.18 \mathrm{E}-05$ \\
${ }^{238} \mathrm{U}$ & $8.02 \mathrm{E}-09$ & $1.05 \mathrm{E}-08$ & $1.03 \mathrm{E}-08$ & $2.15 \mathrm{E}-08$ & $1.95 \mathrm{E}-08$ & $1.68 \mathrm{E}-08$ \\
${ }^{99} \mathrm{Tc}$ & $0.00 \mathrm{E}+00$ & $7.71 \mathrm{E}-05$ & $2.76 \mathrm{E}-05$ & $3.52 \mathrm{E}-05$ & $5.21 \mathrm{E}-05$ & $3.22 \mathrm{E}-05$ \\
& $5.08 \mathrm{E}-05$ & $8.45 \mathrm{E}-05$ & $7.25 \mathrm{E}-05$ & $6.68 \mathrm{E}-05$ & $5.98 \mathrm{E}-05$ & $4.91 \mathrm{E}-05$ \\
\hline
\end{tabular}


Table 11 Continued

\begin{tabular}{|l|cccc|c|c|}
\hline Wash \# & 7 & 8 & 9 & 10 & Total & Solids \\
\hline $\mathrm{Na}^{+}$ & $1.97 \mathrm{E}+00$ & $2.99 \mathrm{E}+00$ & $3.02 \mathrm{E}+00$ & $2.82 \mathrm{E}+00$ & $1.86 \mathrm{E}+01$ & $2.44 \mathrm{E}+00$ \\
$\mathrm{OH}^{-}$ & $2.40 \mathrm{E}-01$ & $1.99 \mathrm{E}-01$ & $3.99 \mathrm{E}-01$ & $3.41 \mathrm{E}-01$ & $1.18 \mathrm{E}+00$ & n.d. \\
$\mathrm{NO}_{3}{ }^{-}$ & $2.34 \mathrm{E}+00$ & $3.79 \mathrm{E}+00$ & $2.53 \mathrm{E}+00$ & $5.38 \mathrm{E}-01$ & $1.88 \mathrm{E}+01$ & n.d. \\
$\mathrm{NO}_{2}{ }^{-}$ & $8.61 \mathrm{E}-02$ & $1.70 \mathrm{E}-01$ & $3.47 \mathrm{E}-01$ & $2.68 \mathrm{E}-01$ & $1.45 \mathrm{E}+00$ & n.d. \\
$\mathrm{Al}(\mathrm{OH})_{4}{ }^{-}$ & $6.00 \mathrm{E}-01$ & $3.71 \mathrm{E}-01$ & $2.77 \mathrm{E}-01$ & $2.44 \mathrm{E}-01$ & $7.56 \mathrm{E}+00$ & $7.63 \mathrm{E}-02$ \\
$\mathrm{CO}_{3}{ }^{2-}$ & $4.28 \mathrm{E}-01$ & $8.45 \mathrm{E}-01$ & $1.12 \mathrm{E}+00$ & $8.00 \mathrm{E}-01$ & $3.76 \mathrm{E}+00$ & n.d. \\
$\mathrm{SO}_{4}{ }^{2-}$ & $1.52 \mathrm{E}-01$ & $3.31 \mathrm{E}-01$ & $3.75 \mathrm{E}-01$ & $5.25 \mathrm{E}-01$ & $1.84 \mathrm{E}+00$ & $8.90 \mathrm{E}-01$ \\
$\mathrm{PO}_{4}{ }^{3-}$ & $1.59 \mathrm{E}-03$ & $1.21 \mathrm{E}-03$ & $2.69 \mathrm{E}-03$ & $2.95 \mathrm{E}-03$ & $3.37 \mathrm{E}-02$ & $0.00 \mathrm{E}+00$ \\
$\mathrm{CrO}_{4}{ }^{2-}$ & $1.37 \mathrm{E}-03$ & $1.77 \mathrm{E}-03$ & $2.67 \mathrm{E}-03$ & $2.99 \mathrm{E}-03$ & $1.60 \mathrm{E}-02$ & $1.78 \mathrm{E}-03$ \\
$\mathrm{MoO}_{4}{ }^{2-}$ & $7.54 \mathrm{E}-04$ & $1.11 \mathrm{E}-03$ & $1.10 \mathrm{E}-03$ & $1.31 \mathrm{E}-03$ & $1.11 \mathrm{E}-02$ & $0.00 \mathrm{E}+00$ \\
$\mathrm{SiO}_{3}{ }^{2-}$ & $7.49 \mathrm{E}-04$ & $7.10 \mathrm{E}-04$ & $6.96 \mathrm{E}-04$ & $1.00 \mathrm{E}-03$ & $4.62 \mathrm{E}-03$ & $4.90 \mathrm{E}-02$ \\
$\mathrm{Cu}^{\mathrm{Sn}}$ & $1.17 \mathrm{E}-04$ & $2.06 \mathrm{E}-04$ & $1.68 \mathrm{E}-04$ & $1.84 \mathrm{E}-04$ & $1.66 \mathrm{E}-03$ & $1.67 \mathrm{E}-03$ \\
${ }^{137} \mathrm{Cs}$ & $5.40 \mathrm{E}-04$ & $7.24 \mathrm{E}-04$ & $6.46 \mathrm{E}-04$ & $9.84 \mathrm{E}-04$ & $6.25 \mathrm{E}-03$ & $4.25 \mathrm{E}-02$ \\
${ }^{90} \mathrm{Sr}$ & $3.18 \mathrm{E}-05$ & $3.42 \mathrm{E}-05$ & $5.68 \mathrm{E}-05$ & $6.83 \mathrm{E}-05$ & $4.15 \mathrm{E}-04$ & $2.66 \mathrm{E}-05$ \\
${ }^{238} \mathrm{U}$ & $1.19 \mathrm{E}-07$ & $8.45 \mathrm{E}-07$ & $1.35 \mathrm{E}-06$ & $3.56 \mathrm{E}-06$ & $5.96 \mathrm{E}-06$ & $1.12 \mathrm{E}-05$ \\
${ }^{99} \mathrm{Tc}$ & $3.66 \mathrm{E}-05$ & $5.26 \mathrm{E}-05$ & $7.23 \mathrm{E}-05$ & $8.69 \mathrm{E}-05$ & $4.73 \mathrm{E}-04$ & $2.17 \mathrm{E}-04$ \\
& $5.00 \mathrm{E}-05$ & $7.28 \mathrm{E}-05$ & $7.82 \mathrm{E}-05$ & $9.36 \mathrm{E}-05$ & $6.78 \mathrm{E}-04$ & $7.78 \mathrm{E}-05$ \\
\hline
\end{tabular}


WSRC-TR-2002-00388

Revision 0

Table 12: Residual Insoluble Solids from Tank 31H Saltcake Dissolution

\begin{tabular}{|c|c|c|c|c|}
\hline & \multicolumn{2}{|c|}{ Inhibited Water Dissolution } & \multicolumn{2}{|c|}{ HLW Supernate Dissolution } \\
\hline & Average (wt \%) & Std. Dev. (wt \%) & Average (wt \%) & Std. Dev. (wt \%) \\
\hline \multicolumn{5}{|c|}{ ICP-ES } \\
\hline $\mathrm{Ag}$ & $<7.84 E-03$ & & $<7.77 E-03$ & \\
\hline $\mathrm{Al}$ & $3.01 \mathrm{E}+01$ & 4.24E-01 & 3.08E-01 & 3.04E-02 \\
\hline $\mathrm{Ba}$ & 8.12E-02 & 1.01E-02 & $<1.85 E-02$ & \\
\hline $\mathrm{Ca}$ & $<2.26 E-02$ & & $<2.23 E-02$ & \\
\hline $\mathrm{Cd}$ & $<4.12 E-03$ & & $<4.08 E-03$ & \\
\hline $\mathrm{Ce}$ & $<2.65 E-02$ & & $<2.63 E-02$ & \\
\hline $\mathrm{Cr}$ & $6.25 \mathrm{E}-02$ & & 1.13E-02 & 3.65E-03 \\
\hline $\mathrm{Cu}$ & 2.67E-02 & 3.54E-04 & 2.38E-02 & 9.19E-04 \\
\hline $\mathrm{Fe}$ & $3.62 \mathrm{E}+00$ & 6.43E-01 & 1.99E-01 & 6.36E-02 \\
\hline Gd & $<2.30 E-02$ & & $<2.27 E-02$ & \\
\hline $\mathrm{K}$ & $<9.20 E-01$ & & $<9.11 E-01$ & \\
\hline $\mathrm{La}$ & $<7.06 E-03$ & & $<7.00 E-03$ & \\
\hline $\mathrm{Li}$ & $<4.22 E-02$ & & $<4.18 E-02$ & \\
\hline $\mathrm{Mg}$ & $\leq 9.96 \mathrm{E}-02$ & & $<5.15 E-03$ & \\
\hline $\mathrm{Mn}$ & $6.20 \mathrm{E}-02$ & $7.50 \mathrm{E}-03$ & 7.31E-03 & 7.57E-04 \\
\hline Mo & $<5.20 E-02$ & & $<5.15 E-02$ & \\
\hline $\mathrm{Na}$ & $1.57 \mathrm{E}+00$ & 1.13E-01 & $3.47 \mathrm{E}+01$ & $1.63 \mathrm{E}+00$ \\
\hline $\mathrm{Ni}$ & 4.85E-02 & 4.31E-03 & $<1.31 E-02$ & \\
\hline$P$ & $<6.77 E-02$ & & $<6.70 E-02$ & \\
\hline $\mathrm{Pb}$ & $<3.13 E-02$ & & $<3.10 E-02$ & \\
\hline$S$ & 7.35E-01 & $2.05 \mathrm{E}-02$ & $4.22 \mathrm{E}+00$ & $2.23 \mathrm{E}+00$ \\
\hline $\mathrm{Sb}$ & $<3.71 E-01$ & & $<3.67 E-01$ & \\
\hline $\mathrm{Si}$ & 8.41E-01 & 1.49E-01 & 2.57E-01 & 1.48E-02 \\
\hline Sn & $6.20 \mathrm{E}-01$ & 4.95E-03 & 6.03E-01 & $1.56 \mathrm{E}-02$ \\
\hline $\mathrm{Sr}$ & $<7.45 E-03$ & & $<7.38 E-03$ & \\
\hline $\mathrm{Ti}$ & $<7.55 E-03$ & & $<7.48 E-03$ & \\
\hline U & $<2.23 E-01$ & & $<2.20 E-01$ & \\
\hline
\end{tabular}


Table 12 Continued

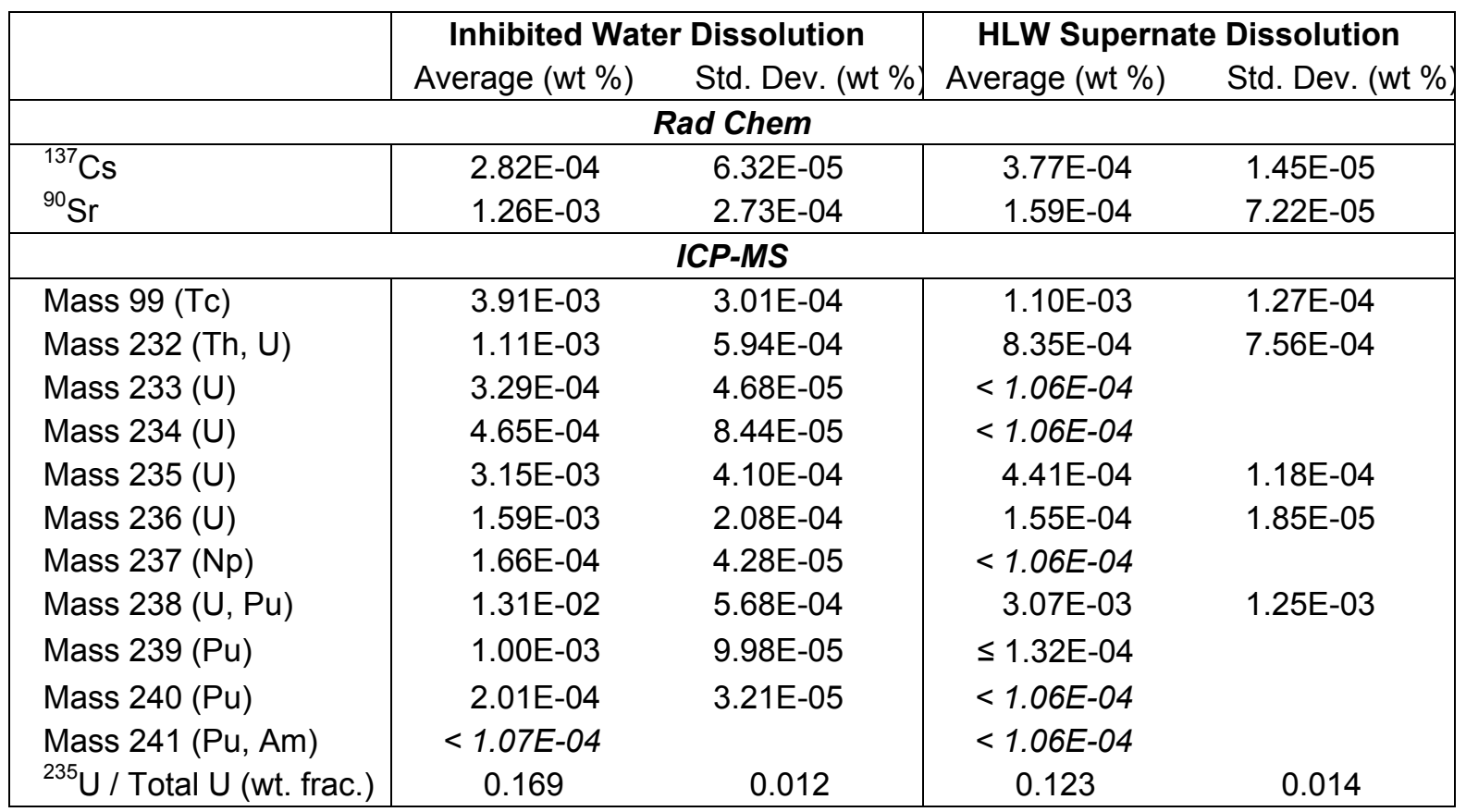

Note: All masses between 230 and 247 (inclusive) that are not reported in

Table 12 were $<1.07 \mathrm{E}-04$ wt $\%$ for the IW dissolution and $<1.06 \mathrm{E}-04 \mathrm{wt} \%$ for the HLW Supernate dissolution. 
WSRC-TR-2002-00388

Revision 0

Table 13: Characterization of As-Received Tank 31H Saltcake (Sample HTK-513)

\begin{tabular}{|c|c|c|c|c|c|}
\hline & \multicolumn{4}{|c|}{ Inhibited Water Dissolution } & \multirow{2}{*}{$\begin{array}{c}\text { Acid } \\
\text { Dissolution }\end{array}$} \\
\hline & Sample 1 & Sample 2 & Sample 3 & Average & \\
\hline \multicolumn{6}{|c|}{ ICP-ES (wt \%) } \\
\hline $\mathrm{Ag}$ & $<3.84 E-04$ & $3.21 \mathrm{E}-04$ & $<3.95 E-04$ & $3.21 \mathrm{E}-04$ & $<7.78 E-03$ \\
\hline $\mathrm{Al}$ & $3.57 \mathrm{E}+00$ & $3.81 \mathrm{E}+00$ & $3.65 E+00$ & $3.68 \mathrm{E}+00$ & $4.95 E+00$ \\
\hline $\mathrm{B}$ & 2.09E-03 & 1.98E-03 & 2.36E-03 & $2.14 \mathrm{E}-03$ & n.d. \\
\hline $\mathrm{Ba}$ & $<9.12 E-04$ & $<6.41 E-04$ & $<9.39 E-04$ & $<8.31 E-04$ & $<1.85 E-02$ \\
\hline $\mathrm{Ca}$ & $<1.10 E-03$ & $<7.76 E-04$ & $<1.14 E-03$ & $<1.01 E-03$ & $<2.24 E-02$ \\
\hline $\mathrm{Cd}$ & $<2.02 E-04$ & $<1.42 E-04$ & $<2.08 E-04$ & $<1.84 E-04$ & $<4.09 E-03$ \\
\hline $\mathrm{Ce}$ & 1.92E-03 & 3.98E-03 & $2.62 \mathrm{E}-03$ & 2.84E-03 & 4.04E-02 \\
\hline $\mathrm{Cr}$ & $5.76 \mathrm{E}-03$ & 5.74E-03 & $6.82 \mathrm{E}-03$ & $6.10 \mathrm{E}-03$ & 7.31E-03 \\
\hline $\mathrm{Cu}$ & $6.29 \mathrm{E}-04$ & $4.22 \mathrm{E}-04$ & $6.62 E-04$ & 5.71E-04 & 2.24E-02 \\
\hline $\mathrm{Fe}$ & $9.84 \mathrm{E}-04$ & 8.23E-04 & $3.22 \mathrm{E}-03$ & $1.68 \mathrm{E}-03$ & 7.41E-02 \\
\hline $\mathrm{Gd}$ & $<1.12 E-03$ & $<7.90 E-04$ & $<1.16 E-03$ & $<1.02 E-03$ & $<2.28 E-02$ \\
\hline $\mathrm{K}$ & $<4.50 E-02$ & $<3.16 E-02$ & $<4.63 E-02$ & $<4.10 E-02$ & $<9.12 E-01$ \\
\hline $\mathrm{La}$ & $<3.45 E-04$ & 5.33E-04 & $4.35 \mathrm{E}-04$ & 4.38E-04 & $<7.00 E-03$ \\
\hline $\mathrm{Li}$ & $<2.06 E-03$ & $<1.45 E-03$ & $<2.12 E-03$ & $<1.88 E-03$ & $<4.18 E-02$ \\
\hline $\mathrm{Mg}$ & $<2.54 E-04$ & $<1.79 E-04$ & $<2.62 E-04$ & $<2.32 E-04$ & 1.73E-02 \\
\hline $\mathrm{Mn}$ & $<3.84 E-05$ & $<2.70 E-05$ & 1.19E-04 & $<6.13 E-05$ & $<7.78 E-04$ \\
\hline Mo & 7.58E-03 & 8.00E-03 & 8.65E-03 & 8.07E-03 & $<5.16 E-02$ \\
\hline $\mathrm{Na}$ & $2.68 \mathrm{E}+01$ & $2.63 E+01$ & $2.88 \mathrm{E}+01$ & $2.73 E+01$ & $2.63 E+01$ \\
\hline $\mathrm{Ni}$ & $<6.48 E-04$ & $<4.55 E-04$ & $<6.67 E-04$ & $<5.90 E-04$ & $<1.31 E-02$ \\
\hline $\mathrm{P}$ & $1.45 \mathrm{E}-02$ & 1.41E-02 & $1.60 \mathrm{E}-02$ & 1.49E-02 & $<6.71 E-02$ \\
\hline $\mathrm{Pb}$ & $<1.53 E-03$ & $<1.08 E-03$ & $<1.58 E-03$ & $<1.39 E-03$ & $<3.10 E-02$ \\
\hline$S$ & $1.48 \mathrm{E}+00$ & $1.36 \mathrm{E}+00$ & $1.68 \mathrm{E}+00$ & $1.51 \mathrm{E}+00$ & $2.04 E+00$ \\
\hline $\mathrm{Sb}$ & $<1.81 E-02$ & $<1.28 E-02$ & $<1.87 E-02$ & $<1.65 E-02$ & $<3.68 E-01$ \\
\hline $\mathrm{Si}$ & $5.90 \mathrm{E}-03$ & 7.39E-03 & 7.76E-03 & 7.02E-03 & 3.13E-01 \\
\hline Sn & 8.01E-03 & 7.39E-03 & $9.49 \mathrm{E}-03$ & 8.30E-03 & $6.02 \mathrm{E}-01$ \\
\hline $\mathrm{Sr}$ & $<3.65 E-04$ & $<2.56 E-04$ & $<3.75 E-04$ & $<3.32 E-04$ & $<7.39 E-03$ \\
\hline $\mathrm{Ti}$ & $<3.69 E-04$ & $<2.60 E-04$ & $<3.80 E-04$ & $<3.37 E-04$ & $1.01 \mathrm{E}-01$ \\
\hline$U$ & $<1.09 E-02$ & $<7.66 E-03$ & $<1.12 E-02$ & $<9.92 E-03$ & $<2.21 E-01$ \\
\hline $\mathrm{Zn}$ & $5.81 \mathrm{E}-04$ & $1.34 \mathrm{E}-03$ & 7.16E-04 & 8.79E-04 & 7.43E-03 \\
\hline $\mathrm{Zr}$ & $<1.09 E-03$ & $<7.69 E-04$ & $<1.13 E-03$ & $<9.97 E-04$ & $<2.22 E-02$ \\
\hline
\end{tabular}


Table 13 Continued

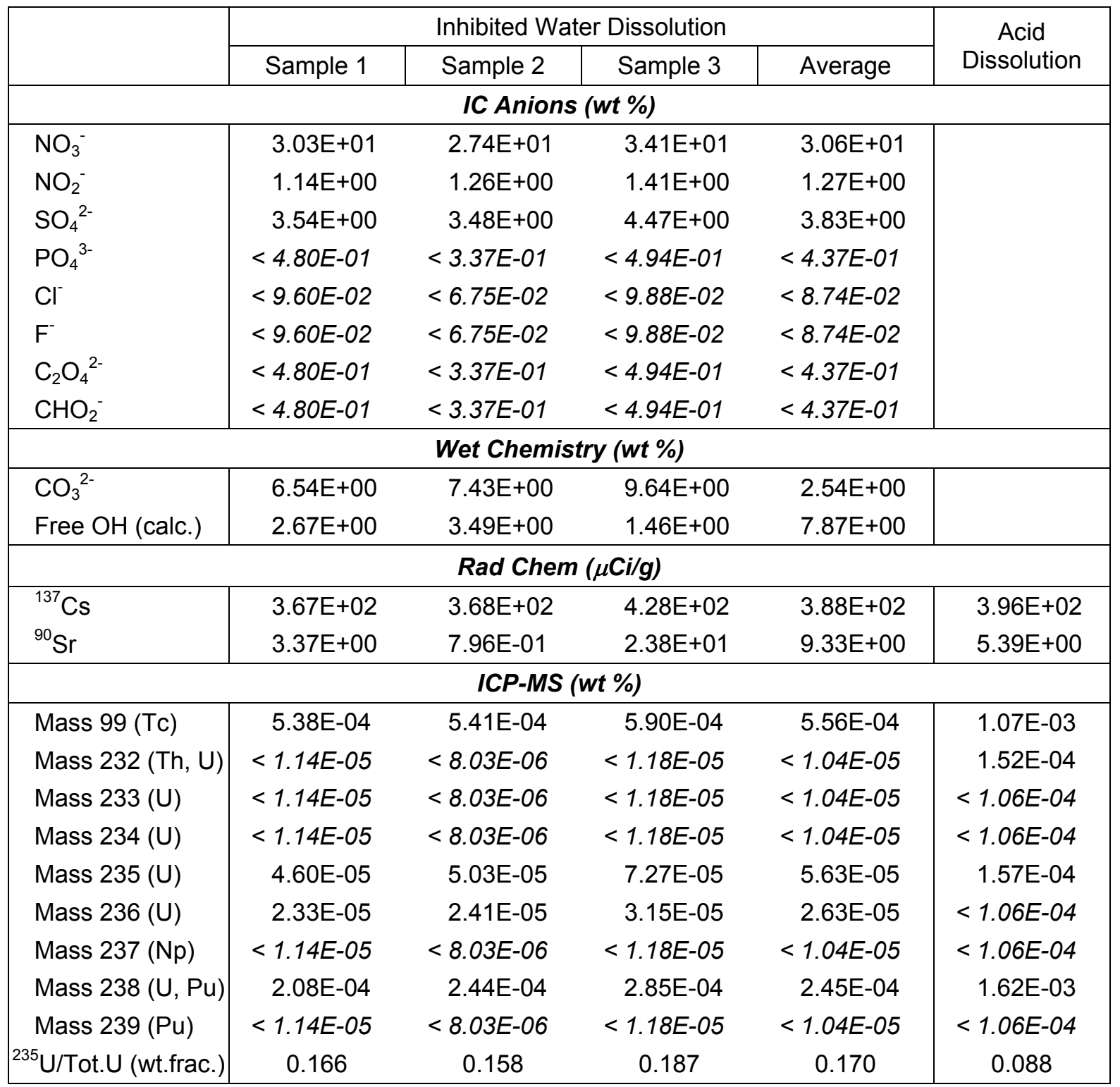


WSRC-TR-2002-00388

Revision 0

Table 14: Characterization of HLW Supernate Composite (from Tanks 21H/24H/26F)

\begin{tabular}{|c|c|c|c|c|c|}
\hline & \multicolumn{4}{|c|}{ Inhibited Water Dissolution } & \multirow{2}{*}{$\begin{array}{c}\text { Acid } \\
\text { Dissolution }\end{array}$} \\
\hline & Sample 1 & Sample 2 & Sample 3 & Average & \\
\hline \multicolumn{6}{|c|}{$I C P-E S(\mathrm{~mol} / \mathrm{L})$} \\
\hline $\mathrm{Ag}$ & $<1.54 E-05$ & $<1.40 E-05$ & $<1.53 E-05$ & $<1.49 E-05$ & $<1.92 E-05$ \\
\hline $\mathrm{Al}$ & $1.99 \mathrm{E}-01$ & $2.00 \mathrm{E}-01$ & 2.09E-01 & $2.02 \mathrm{E}-01$ & $2.45 \mathrm{E}-01$ \\
\hline $\mathrm{B}$ & 1.33E-02 & 1.32E-02 & 1.38E-02 & 1.34E-02 & \\
\hline $\mathrm{Ba}$ & $<2.87 E-05$ & $<2.62 E-05$ & $<2.86 E-05$ & $<2.78 E-05$ & $<3.58 E-05$ \\
\hline $\mathrm{Ca}$ & $<1.19 E-04$ & $<1.09 E-04$ & $<1.19 E-04$ & $<1.15 E-04$ & $<1.49 E-04$ \\
\hline $\mathrm{Cd}$ & $<7.75 E-06$ & $<7.07 E-06$ & $<7.73 E-06$ & $<7.51 E-06$ & $<9.66 E-06$ \\
\hline $\mathrm{Ce}$ & 4.93E-05 & 4.70E-05 & $5.40 \mathrm{E}-05$ & 5.01E-05 & 8.66E-05 \\
\hline $\mathrm{Cr}$ & $2.43 \mathrm{E}-03$ & $2.46 \mathrm{E}-03$ & $2.52 \mathrm{E}-03$ & 2.47E-03 & $3.12 \mathrm{E}-03$ \\
\hline $\mathrm{Cu}$ & 1.64E-04 & 1.63E-04 & 1.71E-04 & $1.66 \mathrm{E}-04$ & 2.61E-04 \\
\hline $\mathrm{Fe}$ & 2.76E-04 & $3.22 \mathrm{E}-04$ & $2.60 \mathrm{E}-04$ & 2.86E-04 & $9.13 \mathrm{E}-04$ \\
\hline $\mathrm{Gd}$ & $<3.09 E-05$ & $<2.81 E-05$ & $<3.08 E-05$ & $<2.99 E-05$ & $<3.85 E-05$ \\
\hline $\mathrm{K}$ & 3.11E-02 & 3.09E-02 & 3.18E-02 & $3.12 \mathrm{E}-02$ & 4.38E-02 \\
\hline $\mathrm{La}$ & $<1.07 E-05$ & $<9.80 E-06$ & $<1.07 E-05$ & $<1.04 E-05$ & $<1.34 E-05$ \\
\hline $\mathrm{Li}$ & $<1.28 E-03$ & $<1.17 E-03$ & $<1.28 E-03$ & $<1.25 E-03$ & $<1.60 E-03$ \\
\hline $\mathrm{Mg}$ & $<4.52 E-05$ & $<4.12 E-05$ & $<4.51 E-05$ & $<4.39 E-05$ & $1.48 \mathrm{E}-04$ \\
\hline $\mathrm{Mn}$ & $1.58 \mathrm{E}-05$ & 1.41E-05 & $1.20 \mathrm{E}-05$ & $1.40 \mathrm{E}-05$ & 4.30E-05 \\
\hline Mo & $4.99 \mathrm{E}-04$ & $4.95 \mathrm{E}-04$ & 5.07E-04 & 5.00E-04 & $6.74 \mathrm{E}-04$ \\
\hline $\mathrm{Na}$ & $5.15 \mathrm{E}+00$ & $5.17 \mathrm{E}+00$ & $5.24 \mathrm{E}+00$ & $5.19 \mathrm{E}+00$ & $6.50 E+00$ \\
\hline $\mathrm{Ni}$ & $<4.77 E-05$ & $<4.35 E-05$ & $<4.76 E-05$ & $<4.63 E-05$ & $<5.94 E-05$ \\
\hline $\mathrm{P}$ & 3.77E-03 & 3.36E-03 & $3.62 \mathrm{E}-03$ & 3.58E-03 & 4.17E-03 \\
\hline $\mathrm{Pb}$ & $<3.19 E-05$ & $<2.91 E-05$ & $<3.18 E-05$ & $<3.10 E-05$ & $<3.98 E-05$ \\
\hline$S$ & 1.47E-02 & 1.52E-02 & 1.53E-02 & $1.50 \mathrm{E}-02$ & 2.83E-02 \\
\hline $\mathrm{Sb}$ & $<6.44 E-04$ & $<5.87 E-04$ & $<6.42 E-04$ & $<6.24 E-04$ & $<8.03 E-04$ \\
\hline $\mathrm{Si}$ & 1.10E-03 & 1.10E-03 & 1.13E-03 & 1.11E-03 & 5.69E-03 \\
\hline Sn & 1.12E-04 & $1.22 \mathrm{E}-04$ & 1.64E-04 & 1.33E-04 & 2.63E-03 \\
\hline $\mathrm{Sr}$ & $<1.80 E-05$ & $<1.64 E-05$ & $<1.79 E-05$ & $<1.74 E-05$ & $<2.25 E-05$ \\
\hline $\mathrm{Ti}$ & $<3.33 E-05$ & $<3.04 E-05$ & $<3.33 E-05$ & $<3.23 E-05$ & $<4.16 E-05$ \\
\hline$U$ & $<1.98 E-04$ & $<1.80 E-04$ & $<1.97 E-04$ & $<1.92 E-04$ & $<2.47 E-04$ \\
\hline $\mathrm{Zn}$ & $1.85 \mathrm{E}-04$ & $1.84 \mathrm{E}-04$ & 1.96E-04 & $1.88 \mathrm{E}-04$ & 1.69E-04 \\
\hline $\mathrm{Zr}$ & $<5.18 E-05$ & $<4.73 E-05$ & $<5.17 E-05$ & $<5.03 E-05$ & $6.42 \mathrm{E}-04$ \\
\hline
\end{tabular}


Table 14 Continued

\begin{tabular}{|c|c|c|c|c|c|}
\hline & \multicolumn{4}{|c|}{ Inhibited Water Dissolution } & \multirow{2}{*}{$\begin{array}{c}\text { Acid } \\
\text { Dissolution }\end{array}$} \\
\hline & Sample 1 & Sample 2 & Sample 3 & Average & \\
\hline \multicolumn{6}{|c|}{ IC Anions (mol/L) } \\
\hline $\mathrm{NO}_{3}^{-}$ & 7.29E-01 & 8.11E-01 & 7.97E-01 & 7.79E-01 & \\
\hline $\mathrm{NO}_{2}^{-}$ & 7.08E-01 & 7.98E-01 & 7.87E-01 & 7.64E-01 & \\
\hline $\mathrm{SO}_{4}^{2-}$ & $<1.08 E-02$ & $<9.85 E-03$ & $<1.08 E-02$ & $<1.05 E-02$ & \\
\hline $\mathrm{PO}_{4}^{3-}$ & $<2.18 E-02$ & $<1.99 E-02$ & $<2.18 E-02$ & $<2.12 E-02$ & \\
\hline $\mathrm{Cl}^{-}$ & $<1.17 E-02$ & $<1.07 E-02$ & $<1.17 E-02$ & $<1.13 E-02$ & \\
\hline $\mathrm{F}^{-}$ & $<2.18 E-02$ & $<1.99 E-02$ & $<2.18 E-02$ & $<2.12 E-02$ & \\
\hline $\mathrm{C}_{2} \mathrm{O}_{4}^{2-}$ & $<2.36 E-02$ & $<2.15 E-02$ & $<2.35 E-02$ & $<2.28 E-02$ & \\
\hline $\mathrm{CHO}_{2}^{-}$ & $<4.61 E-02$ & $<4.20 E-02$ & $<4.59 E-02$ & $<4.47 E-02$ & \\
\hline \multicolumn{6}{|c|}{ Wet Chemistry (mol/L) } \\
\hline Total Base & $3.73 E+00$ & $3.57 \mathrm{E}+00$ & $3.54 \mathrm{E}+00$ & $3.61 \mathrm{E}+00$ & \\
\hline $\mathrm{CO}_{3}^{2-}$ & $<0.0415$ & $<0.0378$ & $<0.0414$ & $<4.02 E-02$ & \\
\hline Free $\mathrm{OH}$ (meas.) & $3.23 E+00$ & $2.97 \mathrm{E}+00$ & $2.87 \mathrm{E}+00$ & $3.02 E+00$ & \\
\hline Free $\mathrm{OH}$ (calc.) & $3.53 E+00$ & $3.37 \mathrm{E}+00$ & $3.33 E+00$ & $3.41 \mathrm{E}+00$ & \\
\hline \multicolumn{6}{|c|}{ Rad Chem (Ci/gal.) } \\
\hline${ }^{137} \mathrm{Cs}$ & $2.73 E+00$ & $2.56 \mathrm{E}+00$ & $2.94 \mathrm{E}+00$ & $2.75 \mathrm{E}+00$ & $7.86 E+00$ \\
\hline${ }^{90} \mathrm{Sr}$ & $2.22 \mathrm{E}-04$ & $2.28 \mathrm{E}-04$ & 2.03E-04 & $2.18 \mathrm{E}-04$ & 1.06E-02 \\
\hline \multicolumn{6}{|c|}{ ICP-MS (mol/L) } \\
\hline Mass $99(\mathrm{Tc})$ & 7.50E-05 & 7.28E-05 & 7.35E-05 & 7.38E-05 & $2.52 \mathrm{E}-04$ \\
\hline Mass $232(\mathrm{Th}, \mathrm{U})$ & & & & & $1.23 \mathrm{E}-06$ \\
\hline Mass $233(U)$ & & & & & $<3.03 E-07$ \\
\hline Mass $234(U)$ & & & & & $<3.01 E-07$ \\
\hline Mass $235(U)$ & 2.36E-07 & 2.14E-07 & 2.21E-07 & $2.24 \mathrm{E}-07$ & 7.30E-07 \\
\hline Mass $236(U)$ & $<2.09 E-07$ & $<1.91 E-07$ & $<2.09 E-07$ & $<2.03 E-07$ & $<2.99 E-07$ \\
\hline Mass $237(\mathrm{~Np})$ & $<2.08 E-07$ & $<1.90 E-07$ & $<2.08 E-07$ & $<2.02 E-07$ & $<2.97 E-07$ \\
\hline Mass $238(\mathrm{U}, \mathrm{Pu})$ & 3.02E-05 & 3.03E-05 & 2.94E-05 & $3.00 \mathrm{E}-05$ & 1.05E-04 \\
\hline Mass $239(\mathrm{Pu})$ & $<2.06 E-07$ & $<1.88 E-07$ & $<2.06 E-07$ & $<2.00 E-07$ & $<2.95 E-07$ \\
\hline${ }^{235} \mathrm{U} /$ Tot.U (wt.frac.) & 0.00767 & 0.00694 & 0.00738 & 0.00733 & 0.00681 \\
\hline
\end{tabular}

